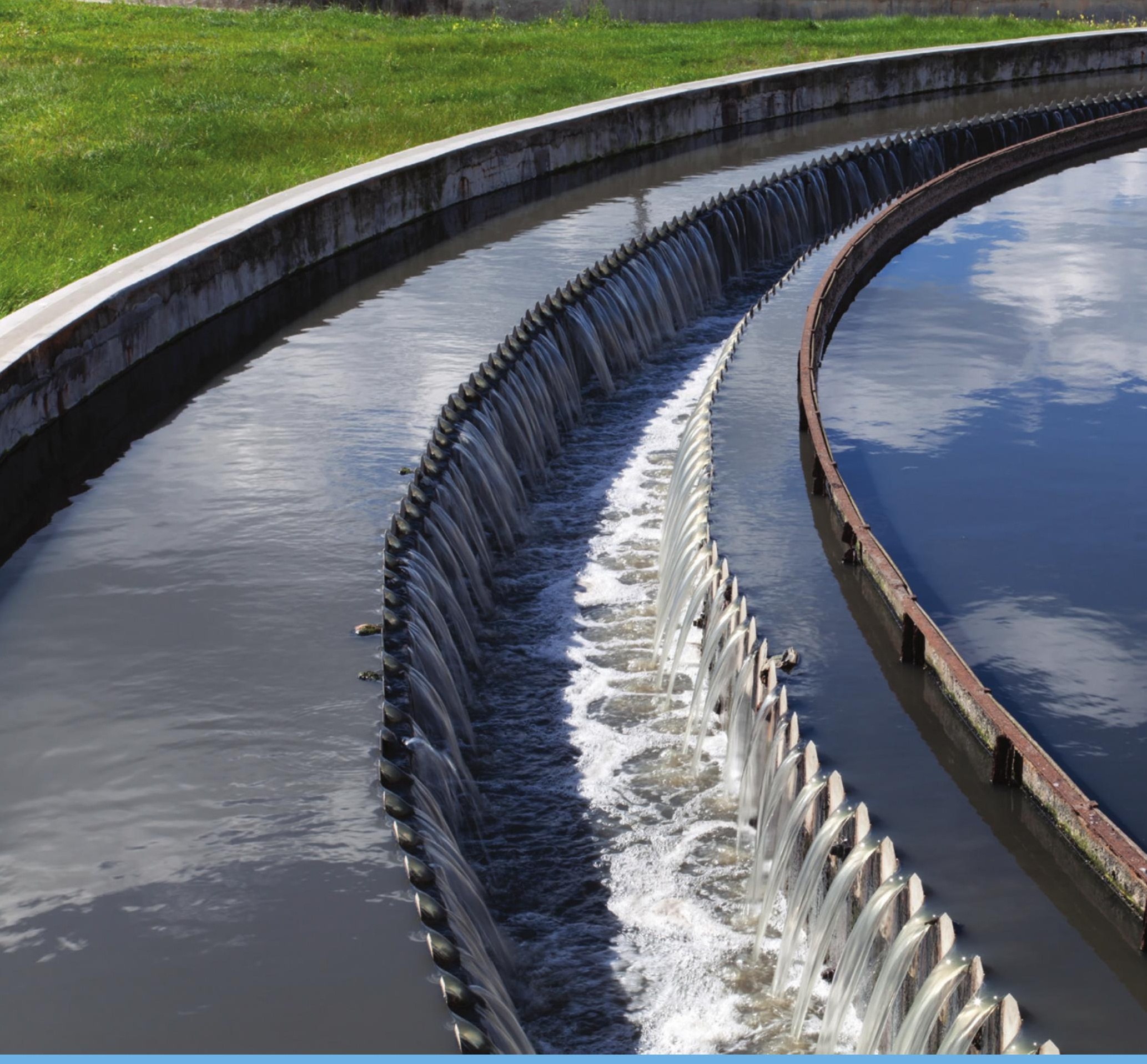

\title{
Perspectieven voor de afzet van (fosfaat- verarmd) zuiveringsslib naar de landbouw
}

Inge Regelink, Phillip Ehlert, Paul Römkens

$\square \quad \begin{aligned} & \text { WAGEN INGEN } \\ & \text { UNIVERSITY \& RESEARCH }\end{aligned}$ 



\section{Perspectieven voor de afzet van (fosfaat- verarmd) zuiveringsslib naar de landbouw}

Inge Regelink, Phillip Ehlert, Paul Römkens

Dit onderzoek is uitgevoerd door Wageningen Environmental Research (Alterra) in opdracht van STOWA (Stichting Toegepast Onderzoek Waterbeheer), Waterschap Rijn en IJssel, Waterschap Aa en Maas en GMB BioEnergie, met ondersteuning van TKI Deltatechnologie.

Wageningen Environmental Research

Wageningen, juli 2017

Rapport 2819

ISSN 1566-7197 
Regelink, I.C., P.A.I. Ehlert, P.F.A.M Römkens, 2017. Perspectieven voor de afzet van (fosfaatverarmd) zuiveringsslib naar de landbouw. Wageningen, Wageningen Environmental Research, Rapport 2819. 76 blz.; 29 fig.; 25 tab.; 66 ref.

Zuiveringsslib vormt een bron van waardevolle nutriënten en organische stof die grotendeels verloren gaan met huidige thermische verwerkingsroutes. Toepassing van (verwerkt) slib in de landbouw wordt gezien als een mogelijkheid om nutriënten uit slib nuttig te hergebruiken en gelijktijdig de verwerkingskosten voor zuiveringsslib te verlagen. In dit project zijn de perspectieven beoordeeld voor de verwerking en afzet van zuiveringsslib in de vorm van minerale fosfaatmeststof en fosfaatverarmde bodemverbeteraar. Hiervoor zijn ten eerste huidige wettelijke kaders en regelgeving rondom het landbouwkundig gebruik van zuiveringsslib benoemd, evenals ontwikkelingen op dit vlak. Verder zijn de afzetmogelijkheden van slib en slibproducten in de landbouw beschreven, rekening houdend met de concurrentie met de afzet van dierlijke mest. De mogelijkheden tot het scheiden van slib in een minerale fosfaatmeststof en fosfaat-verarmd slib zijn verkend in laboratoriumtesten met slib van negen RWZI's. Tevens is een milieurisicobeoordeling uitgevoerd waarbij de belasting van landbouwgronden met zware metalen bij bemesting met zuiveringsslib is vergeleken met referentiescenario's waarin wordt bemest met dierlijke mest en/of compost.

Trefwoorden: afvalwater, contaminanten, fosfaat, meststof, RWZI, zuiveringsslib, zware metalen

Dit rapport is gratis te downloaden van https://doi.org/10.18174/420057 of op www.wur.nl/environmental-research (ga naar 'Wageningen Environmental Research' in de grijze balk onderaan). Wageningen Environmental Research verstrekt geen gedrukte exemplaren van rapporten.

(C) 2017 Wageningen Environmental Research (instituut binnen de rechtspersoon Stichting Wageningen Research), Postbus 47, 6700 AA Wageningen, T 03174807 00, E info.alterra@wur.nl, www.wur.nl/environmental-research. Wageningen Environmental Research is onderdeel van Wageningen University \& Research.

- Overname, verveelvoudiging of openbaarmaking van deze uitgave is toegestaan mits met duidelijke bronvermelding.

- Overname, verveelvoudiging of openbaarmaking is niet toegestaan voor commerciële doeleinden en/of geldelijk gewin.

- Overname, verveelvoudiging of openbaarmaking is niet toegestaan voor die gedeelten van deze uitgave waarvan duidelijk is dat de auteursrechten liggen bij derden en/of zijn voorbehouden.

Wageningen Environmental Research aanvaardt geen aansprakelijkheid voor eventuele schade voortvloeiend uit het gebruik van de resultaten van dit onderzoek of de toepassing van de adviezen.

Wageningen Environmental Research Rapport 2819 | ISSN 1566-7197

Foto omslag: Shutterstock 


\section{Inhoud}

$\begin{array}{ll}\text { Samenvatting } & \mathbf{5}\end{array}$

$\begin{array}{lll}1 & \text { Inleiding } & 7\end{array}$

$\begin{array}{lll}1.1 & \text { Aanleiding } & 7\end{array}$

1.2 Doelstelling en onderzoeksvragen $\quad 8$

2.1 Inleiding 9

2.1.1 Europese richtlijn gebruik zuiveringsslib 9

2.1.2 Besluit Gebruik Meststoffen en Uitvoeringsbesluit Meststoffenwet 10

2.1.3 Andere EU-lidstaten $\quad 12$

2.2 Landbouwkundig gebruik van zuiveringsslib in Europese lidstaten 13

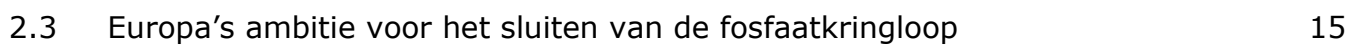

$\begin{array}{lll}2.4 & \text { Nieuwe Europese regelgeving voor meststoffen } & 17\end{array}$

$\begin{array}{llr}2.5 & \text { Conclusies } & 18\end{array}$

3.1 Inleiding $\quad 19$

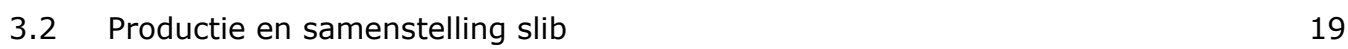

$\begin{array}{lll}3.3 & \text { Markt voor meststoffen en bodemverbeteraars } & 20\end{array}$

$\begin{array}{ll}\text { 3.3.1 Gebruiksnormen } & 20\end{array}$

$\begin{array}{ll}3.3 .2 \text { Concurrentie dierlijke mest } & 21\end{array}$

$\begin{array}{ll}\text { 3.3.3 Organische bodemverbeteraars } & 22\end{array}$

3.3.4 Export van gecomposteerd slib $\quad 22$

3.3.5 Herwonnen fosfaatmeststoffen $\quad 23$

3.4 Positionering van slib als meststof of bodemverbeteraar $\quad 23$

3.4.1 Economische waarde van slib bij afzet in de landbouw $\quad 25$

$\begin{array}{lll}3.5 & \text { Conclusies } & 26\end{array}$

$4 \quad$ Verwijdering en terugwinning van fosfaat $\quad 27$

$\begin{array}{lll}4.1 & \text { Inleiding } & 27\end{array}$

$\begin{array}{lll}4.2 & \text { Materiaal en methoden } & 28\end{array}$

4.2.1 Selectie van RWZI's en slibmonsters $\quad 28$

4.2.2 Karakterisering slib 29

4.2.3 Extracties met zwavelzuur $\quad 29$

4.2.4 Extracties met citroenzuur of natriumbicarbonaat 29

4.2.5 Fosfaatterugwinning in combinatie met hydrothermale carbonisatie $\quad 30$

$\begin{array}{lll}4.3 & \text { Resultaten } & 30\end{array}$

4.3.1 Samenstelling zuiveringsslib $\quad 30$

4.3.2 Zuurbufferend vermogen van zuiveringsslib 32

4.3.3 Extractie van fosfaat uit ontwaterde slibkoek 33

4.3.4 Extractie van fosfaat uit ingedikt slib $\quad 35$

4.3.5 Consequenties van ijzer- en aluminiumdoseringen op de RWZI 37

4.3.6 Zuurdosering 38

4.3.7 Extractie van zware metalen $\quad 39$

4.3.8 Fosfaatextractie met citroenzuur of loog 41

4.3.9 Effect van hydrothermale carbonisatie op fosfaatextractie 43

4.4 Perspectieven en kosten/baten 43

$\begin{array}{lll}4.5 & \text { Conclusies } & 47\end{array}$ 
5.1 Inleiding $\quad 48$

5.2 Modelbeschrijving, materiaal en methoden 49

5.2.1 Modelbeschrijving milieurisicobeoordeling 49

5.2.2 Materiaal en methoden - reactiviteit zware metalen $\quad 51$

5.3 Resultaten $\quad 51$

5.3.1 Trends in gehalten aan zware metalen in slib 51

5.3.2 Gehalten aan zware metalen in slib $\quad 52$

5.3.3 Bemestingsscenario's $\quad 55$

5.3.4 Belasting van de bodem met zware metalen $\quad 55$

5.3.5 Risico's van zware metalen voor de landbouw $\quad 57$

5.3.6 Risico's voor uitspoeling van zware metalen 58

5.3.7 Reactiviteit van zware metalen in slib en slibproducten 60

5.3.8 Microbiologische kwaliteit $\quad 62$

$\begin{array}{lll}5.4 & \text { Conclusies } & 63\end{array}$

$\begin{array}{ll}\text { Synthese en perspectieven } & 64\end{array}$

$\begin{array}{lll}6.1 & \text { Synthese } & 64\end{array}$

6.1.1 Aanleiding 64

6.1.2 Toekomstperspectieven in relatie tot beleidsontwikkelingen 64

6.1.3 Landbouwkundige waarde zuiveringsslib 64

6.1.4 Fosfaatverwijdering en terugwinning 65

6.1.5 Milieurisicobeoordeling (zware metalen) bij landbouwkundig gebruik van zuiveringsslib 66

$\begin{array}{lll}6.2 & \text { Perspectieven } & 66\end{array}$

$\begin{array}{ll}\text { Literatuur } & 68\end{array}$

$\begin{array}{lll}\text { Bijlage 1 Analysemethoden } & \mathbf{7 1}\end{array}$

$\begin{array}{lll}\text { Bijlage } 2 & \text { Zuurtitraties zuiveringsslib } & 73\end{array}$ 


\section{Samenvatting}

Nederlandse waterschappen produceren gezamenlijk 1,3 miljoen ton communaal zuiveringsslib. Dit slib vormt een bron van waardevolle nutriënten en organische stof welke grotendeels verloren gaan met huidige thermische verwerkingsroutes. Waterschappen hebben daarom de ambitie uitsproken om alternatieve afzetroutes te ontwikkelen waarbij energiewinning (energiefabriek) en hergebruik van waardevolle componenten (grondstoffenfabriek) een centrale plaats innemen. Toepassing van (verwerkt) slib in de landbouw wordt gezien als een mogelijkheid om nutriënten uit slib nuttig te hergebruiken en gelijktijdig de verwerkingskosten voor zuiveringsslib te verlagen. In dit project is beoordeeld of er perspectieven zijn voor de verwerking van zuiveringsslib tot een minerale fosfaatmest en een P-verarmde bodemverbeteraar alsmede perspectieven voor de afzet van deze producten naar de landbouw. Hiervoor zijn de volgende aspecten in beschouwing genomen:

(i) beleidsmatige ontwikkelingen ten aanzien van meststoffen en gebruik van afvalstromen als grondstof voor meststof, (ii) afzetmogelijkheden en landbouwkundige waarde van slibproducten, (iii) mogelijkheden tot het scheiden van slib in mineraal fosfaat en fosfaat-verarmde meststof en (iv) de milieurisico's ten aanzien van zware metalen bij gebruik van slib als meststof.

Om de transitie naar een circulaire economie te stimuleren, introduceert de Europese Commissie een pakket aan maatregelen waaronder een nieuwe meststoffenverordening waardoor de handel in meststoffen met voorheen een afvalstatus onder voorwaarden wordt toegestaan. Echter, zuiveringsslib is expliciet uitgesloten waardoor slib niet zal worden toegelaten tot het vrije handelsverkeer, ondanks het feit dat communaal slib voldoet aan de normen voor zware metalen in organische EU-meststoffen. Mogelijk zullen bepaalde producten uit communaal afvalwater (struviet, biochar, verbrandingsassen) onder voorwaarden wel toegelaten worden tot het vrije handelsverkeer in de EU. Dit wordt pas in 2018 duidelijk. Verder heeft de Europese Commissie de ambitie om de afhankelijkheid van externe fosfaatbronnen terug te dringen, maar verplichte fosfaatterugwinning uit zuiveringsslib is vooralsnog niet voorzien.

De landbouwkundige waarde en afzetmogelijkheden van slib hangen grotendeels samen met de slibsamenstelling. Zuiveringsslib kenmerkt zich door een hoog fosfor ( $\mathrm{P}-$ ) gehalte en moet zich primair positioneren als een organische meststof (i.e. een bron van nutriënten). Vanwege het P-overschot in de Nederlandse landbouwsector is een hoog P-gehalte ongunstig bij afzet in Nederland. Bij export van slib is een hoog fosfaatgehalte daarentegen wel waardeverhogend. Export van slibproducten zoals biogranulaat is echter juridisch complex vanwege de afvalstatus van het product. Indien het fosfaatgehalte van het slib verlaagd wordt, sluit de nutriëntensamenstelling van het product beter aan bij de vraag vanuit de Nederlandse landbouw en neemt de mate van verdringing van dierlijke mest af. Wanneer het fosfaatgehalte met circa $75 \%$ wordt verlaagd, ontstaat een meststof die qua samenstelling (fosfaat, stikstof, organische stof) overeenkomt met rundermest. Rundermest is, tegen betaling, goed te plaatsen in de akkerbouw. Om zuiveringsslib te verwerken tot een organische bodemverbeteraar (i.e. vervanger van compost), dient het fosfaatgehalte met ruim $85 \%$ verlaagd te worden én moet het product overeenkomstig compost - in aanmerking komen voor een fosfaatvrije voet.

Het P-gehalte van zuiveringsslib kan verlaagd worden door het fosfaat te verwijderen en terug te winnen door middel van een zuur- en baseprocedé. Uitgevoerd experimenteel onderzoek aan slibmonsters van 9 RWZI's toont aan dat 72-82\% van het fosfaat uit slibkoek in oplossing gebracht kan worden door het slib met zwavelzuur aan te zuren tot $\mathrm{pH} 3$. Voor het aanzuren van één ton slibkoek ( $\approx 25 \%$ droge stof) is ongeveer 36 liter zwavelzuur (96\%) nodig. Na scheiding kan het opgeloste fosfaat door dosering van calciumhydroxide worden teruggewonnen. Naar schatting kan circa 58-65\% van het P-totaal daadwerkelijk teruggewonnen worden. Voorwaarde is wel dat het ijzergehalte van het slib voldoende laag is (Fe/P ratio $<0.4 \mathrm{~mol} / \mathrm{mol}$ ). Het slib van ongeveer de helft van de RWZI's kan aan deze voorwaarde voldoen. Zware metalen gaan niet of beperkt (zink, nikkel) in oplossing tijdens het aanzuren van slib, waardoor gehalten aan zware metalen in het herwonnen fosfaat laag zijn. De kosten voor het verbruik van zwavelzuur en calciumhydroxide worden geschat op 
$€ 6$,- per ton slibkoek. Hier staat tegenover dat de slibmassa met ruim $6 \%$ afneemt en dat de ontwatering zal verbeteren, waardoor bespaard kan worden op de slib-afvoerkosten en het polymeerverbruik. Daarnaast is fosfaatverwijdering gunstig wanneer slib in gedroogde vorm wordt afgezet als biobrandstof, omdat de hoeveelheid asresten met circa 30\% afneemt. Landbouwkundig gebruik van het $\mathrm{P}$-verarmd slib is onder de huidige wetgeving niet mogelijk, omdat de mate van mobilisatie van metalen na aanzuring zeer beperkt is waardoor geen substantiële kwaliteitsverbetering van slib m.b.t. gehalten aan zware metalen gerealiseerd wordt.

Landbouwkundig gebruik van zuiveringsslib is in Nederland toegestaan, maar de aanwending van communaal slib wordt belemmerd doordat deze niet voldoet aan de normen voor koper en zink en, in mindere mate, lood en nikkel volgens het Uitvoeringsbesluit Meststoffenwet (UBM). De mate van accumulatie van koper en zink in landbouwgronden bij aanwending van slib en P-verarmd slib (50\%) is echter gelijk aan of lager dan die bij gebruik van dierlijke mest. Voor andere zware metalen is de mate van accumulatie in de bodem verwaarloosbaar. Wanneer het fosfaatgehalte van het slib met $75 \%$ of meer wordt verlaagd, neemt de belasting van zware metalen duidelijk toe ten opzichte van referentiescenario's op basis van gebruik van dierlijke mest. De belasting van landbouwbodems met koper en zink leidt tot een toename in de uitspoeling van deze metalen naar grond- en oppervlaktewater, maar ook hiervoor geldt dat dit in dezelfde mate gebeurt als bij aanwending van dierlijke mest. Langdurig gebruik van zuiveringsslib leidt niet tot overschrijding van landbouwkundige advieswaarden en brengt geen risico's met zich mee voor gewaskwaliteit. De beoordeling van de kwaliteit van slib t.a.v. het gebruik in de landbouw is vooralsnog gebaseerd op de bepaling van de totaalgehalten aan zware metalen (met Aqua Regia). Dit terwijl de potentiële beschikbaarheid of reactiviteit van zware metalen (bepaald met een $0.43 \mathrm{M} \mathrm{HNO}_{3}$-extractie) een betere voorspeller is voor milieueffecten. Na composteren van zuiveringsslib neemt de reactiviteit van koper en nikkel met respectievelijk 75 en $50 \%$ af ten opzichte van die in niet-verwerkt slib. Wanneer het slib met hydrothermale carbonisatie wordt verwerkt, neemt daarnaast ook de reactiviteit van zink sterk af. Indien toekomstige milieunormen worden afgeleid op basis van reactiviteit in plaats van op totaalgehalten, leidt dit daarom tot een substantiële verruiming van de afzetmogelijkheden van gecomposteerd of hydrothermaal verwerkt slib in de landbouw.

Op basis van deze studie komt naar voren dat de verwerking van slib tot een minerale fosfaatmeststof en een P-verarmde slibstroom een gunstig alternatief kan vormen voor huidige thermische verwerkingsroutes. Het is praktisch gezien haalbaar om een voldoende hoog aandeel $P$ te verwijderen tegen een acceptabele zuurdosering. Op de korte termijn biedt deze route voordelen door een lagere slibproductie, een (te verwachten) verbeterde ontwatering en een verbeterde afzetwaarde bij gebruik van gedroogd slib als biobrandstof. Afzet van slib als biobrandstof is een hoogwaardigere toepassing dan thermische slibverwerking in monoverbranders waarbij netto gezien geen energie wordt gewonnen. De perspectieven voor een verdere verwaarding van de organische fractie in de vorm van meststof/bodemverbeteraar zijn vooralsnog onzeker. Op de korte termijn wordt deze route belemmerd door het feit dat slib niet aan de normen voor zware metalen (met name koper, zink) kan voldoen. Een kanttekening die daarbij gemaakt moet worden, is dat de aanvoer van zowel koper als zink via mest in dezelfde orde van grootte ligt als die bij gebruik van P-verarmd slib (tot 50\% P-verlaging). Afzetmogelijkheden van slib en slibproducten kunnen in de toekomst echter toenemen, omdat de toekomstige milieuwetgeving rekening gaat houden met de reactiviteit van metalen. Wanneer toepassing is toegestaan, zal het P-verarmde slib concurrentie ondervinden van mest en mestproducten waardoor de toekomstige marktwaarde en acceptatie samenhangen met de ontwikkelingen op de mestmarkt. 


\section{$1 \quad$ Inleiding}

\section{$1.1 \quad$ Aanleiding}

Nederlandse waterschappen produceren gezamenlijk 1,3 miljoen ton communaal zuiveringsslib (CBS, 2016). Zuiveringsslib vormt een bron van potentieel waardevolle nutriënten en organische stof die grotendeels verloren gaan met huidige thermische verwerkingsroutes. Als gevolg van het streven naar een duurzamer gebruik van reststromen, waarbij energiewinning (energiefabriek) en hergebruik van waardevolle componenten (grondstoffenfabriek) een centrale plaats innemen, hebben waterschappen de ambitie uitsproken om alternatieve afzetroutes te ontsluiten. Het terugwinnen van nutriënten en hergebruiken van slib en slibproducten in de landbouw vormt hierin een belangrijk aspect.

Het gebruik van zuiveringsslib als meststof is een van de efficiëntste manieren voor nuttig hergebruik van organische stof en nutriënten. Toch wordt zuiveringsslib in Nederland al enkele decennia niet meer in de landbouw gebruikt. De afzet van zuiveringsslib naar de landbouw wordt belemmerd door een aantal factoren. Ten eerste moet het fosfaatrijke zuiveringsslib bij afzet naar de landbouw concurreren met dierlijke mest en andere (an)organische meststoffen. Ten tweede is het gebruik van communaal zuiveringsslib veelal niet mogelijk omdat normen voor zware metalen in slib overschreden worden. Ten derde heeft zuiveringsslib te kampen met een negatief imago door hoge gehalten aan zware metalen in het verleden en tegenwoordig ook de zogenaamde 'nieuwe' verontreinigingen (medicijnresten e.d.). De gehalten aan zware metalen in zuiveringsslib zijn tegenwoordig lager dan die in de jaren tachtig van de vorige eeuw door saneringen aan de bron. Toch is het gebruik van zuiveringsslib in de landbouw niet aantrekkelijk en veelal niet toegestaan. Echter, er vinden nu diverse ontwikkelingen plaats op het gebied van technologie, milieurisicobeoordeling en beleid, waardoor er voor de toekomst mogelijk nieuwe perspectieven ontstaan voor de afzet van slib(producten) naar de landbouw.

Op technologisch vlak zijn er diverse ontwikkelingen gaande op het gebied van slibverwerking en terugwinning van nutriënten. Hierdoor ontstaan mogelijkheden om de samenstelling en eigenschappen van slibproducten af te stemmen op de vraag van de markt. Met de ontwikkeling van methoden voor het extraheren en terugwinnen van fosfaat uit zuiveringsslib wordt het mogelijk om zuiveringsslib te scheiden in een minerale fosfaatmeststof en een fosfaat-verarmde organische bodemverbeteraar. Het herwonnen fosfaat kan geëxporteerd worden en het fosfaat-verarmde slib zou, onder voorwaarden, afgezet kunnen worden naar de landbouw.

De milieu-hygiënische kwaliteit van zuiveringsslib is sinds de jaren tachtig sterk verbeterd. Echter, normen voor koper en zink worden nog altijd overschreden waardoor de afzet van communaal slib in de landbouw niet is toegestaan. Deze normen zijn afgeleid op basis van een voorzorgsprincipe, i.e. het voorkómen van accumulatie van zware metalen in landbouwgronden. Op basis van wetenschappelijke inzichten is echter bekend dat totaalgehalten aan zware metalen niet per se een goede indicatie geven van eventuele milieurisico's. In milieurisicobeoordelingen wordt zodoende meer en meer aandacht gegeven aan de mate van reactiviteit en biobeschikbaarheid van zware metalen onder de beoogde toepassing.

Daarnaast bestaan er voor koper en zink, de voor slib meest knellende zware metalen, grote verschillen in normen tussen EU-lidstaten en voor diverse meststoffen. Zo is ten tijde van dit rapport voorzien dat koper en zink in de toekomstige meststoffenverordeningen niet meer gereguleerd zullen worden, omdat deze metalen beschouwd worden als micronutriënten in plaats van contaminanten. Deze nieuwe wet is onderdeel van het pakket aan maatregelen dat de Europese Commissie doorvoert om de transitie naar een circulaire economie te faciliteren. De nieuwe meststoffenverordening is niet van toepassing op zuiveringsslib (zuiveringsslib is geen meststof), maar toont wel aan dat de beeldvorming rondom meststoffen uit afvalproducten verandert en de acceptatie van dergelijke producten toeneemt. 
In deze studie wordt een verkenning uitgevoerd naar de mogelijkheden om zuiveringsslib in de toekomst te verwerken tot (grondstoffen voor) meststoffen en om deze producten in de landbouw af te zetten. Hiervoor is aandacht besteed aan de mogelijkheden om zuiveringsslib te scheiden in een fosfaat-verarmde organische stof en een minerale fosfaatmeststof. Tevens is een milieurisicobeoordeling uitgevoerd waarbij de belasting van landbouwgronden met zware metalen bij het gebruik van slib(producten) als meststof is doorgerekend. Op basis van de marktvraag naar meststoffen, de mogelijkheden om te sturen op de samenstelling van slibproducten en de uitkomsten van de milieurisico-beoordeling, is aangegeven wat de kansen en knelpunten zijn voor de afzet van slibproducten in de landbouw.

\subsection{Doelstelling en onderzoeksvragen}

Het project heeft als doel om nieuwe afzetroutes te formuleren waarbij zuiveringsslib op een duurzame wijze wordt verwerkt tot meststoffen en bodemverbeteraars zodat waardevolle nutriënten en organische stof worden hergebruikt.

Om de perspectieven voor deze nieuwe afzetroutes in kaart te brengen, zijn de volgende onderzoeksvragen geformuleerd:

- Welke ontwikkelingen zijn er gaande op het gebied van wetgeving voor zuiveringsslib en meststoffen? (Hoofdstuk 2)

- Wat is de landbouwkundige waarde van zuiveringsslib en slibproducten? (Hoofdstuk 3)

- Is het haalbaar om zuiveringsslib te scheiden in een minerale fosfaatmeststof en een fosfaatverarmde organische meststof of bodemverbeteraar? (Hoofdstuk 4)

- Wat zijn de milieukundige gevolgen van de belasting van landbouwbodems met zware metalen bij het gebruik van zuiveringsslib of fosfaat-verarmde slibproducten? (Hoofdstuk 5)

- Synthese en conclusies (Hoofdstuk 6) 


\section{$2 \quad$ Regelgeving bij landbouwkundig gebruik van zuiveringsslib}

\section{$2.1 \quad$ Inleiding}

Dit hoofdstuk geeft een kort overzicht van de wettelijke kaders en regelgeving voor het landbouwkundig gebruik van zuiveringsslib in EU-lidstaten en meer specifiek voor Nederland. Paragraaf 2.2 geeft daarnaast een overzicht van het gebruik van zuiveringsslib in andere EU-lidstaten. Verder wordt een doorkijk gegeven naar de toekomstige ontwikkelingen op het gebied van Europese wetgeving voor meststoffen (niet-zijnde slib) en ambities voor hergebruik van fosfaten (paragraaf 2.42.5). Deze ontwikkelingen worden gedreven door de transitie naar een circulaire economie.

\subsubsection{Europese richtlijn gebruik zuiveringsslib}

De Europese Commissie staat het gebruik van zuiveringsslib in de landbouw toe onder voorwaarden die zijn opgenomen in de Europese Richtlijn 86/278 - Bescherming van de bodem bij het gebruik van zuiveringsslib in de landbouw (EG, 1986). De richtlijn stelt regels aan het gebruik van zuiveringsslib via eisen aan zware metalen in de bodem, zware metalen in slib en maximale jaarlijkse hoeveelheden zware metalen die aan de bodem mogen worden toegevoegd. Daarnaast zijn er wachttermijnen gesteld voor het gebruik in akkerbouw, tuinbouw, fruitteelt en veehouderij (weidegang van graasdieren).

Richtlijn 86/278/EEG stelt de regels vast voor het gebruik door landbouwers van zuiveringsslib als meststof, zodat het slib het milieu en de menselijke gezondheid niet schaadt door het aantasten van de kwaliteit van de bodem of het oppervlakte- en grondwater. Daartoe bepaalt ze de maximaal toegestane waarden voor de concentratie in de bodem van zeven zware metalen $(\mathrm{Cd}, \mathrm{Cr} \mathrm{Cu}, \mathrm{Hg}, \mathrm{Ni}$, $\mathrm{Pb}, \mathrm{Zn}$ ) die giftig kunnen zijn voor planten en mensen. Ze verbiedt het gebruik van zuiveringsslib wanneer de concentratie van een of meer zware metalen in de bodem de grenswaarden overschrijdt. Over het algemeen moet slib een hygiëniserende behandeling ondergaan voordat het in de landbouw kan worden gebruikt. Een EU-land kan het gebruik van niet-behandeld slib evenwel onder bepaalde voorwaarden toestaan indien het in de grond wordt geïnjecteerd of ondergeploegd.

In bepaalde omstandigheden mag er helemaal geen slib worden gebruikt in de landbouw: (i) op weideland of velden voor de teelt van voedergewassen die worden begraasd door dieren, en gedurende een termijn van ten minste drie weken voordat voedergewassen worden geoogst; (ii) op groente- en fruitaanplant, met uitzondering van die van fruitbomen, gedurende de groeiperiode; en (iii) op bodems die bestemd zijn voor de teelt van groenten of vruchten die normaliter in rechtstreeks contact met de bodem staan en rauw worden geconsumeerd, gedurende een periode van tien maanden voorafgaand aan de oogst en tijdens de oogst zelf.

De nationale autoriteiten zijn verantwoordelijk om ervoor te zorgen dat het gebruik van slib door landbouwers de wettelijke grenswaarden niet overschrijdt. Daartoe moeten ze monsters nemen van het slib en de bodem waarop het wordt gebruikt en die analyseren en registers bijhouden van:

- de hoeveelheden geproduceerd en aan de landbouw geleverd slib;

- de samenstelling en eigenschappen van het slib;

- de behandelingsmethode;

- de ontvangers van het slib en de plaatsen waar het wordt gebruikt.

De Europese Commissie publiceert regelmatig een rapport over het gebruik van slib in de EUlandbouw, waarin ze de informatie samenbrengt die de verschillende landen over dit onderwerp hebben gerapporteerd. 


\subsubsection{Besluit Gebruik Meststoffen en Uitvoeringsbesluit Meststoffenwet}

Het gebruik van zuiveringsslib in de Nederlandse landbouw is geregeld in het Besluit Gebruik Meststoffen. Criteria voor de samenstelling zijn opgenomen in het Uitvoeringsbesluit Meststoffenwet.

\section{Besluit Gebruik Meststoffen}

De voorwaarden waaronder het gebruik van zuiveringsslib in de landbouw is toegestaan, zijn beschreven in artikel 1b van het Besluit Gebruik Meststoffen. De doseringsvoorschriften bedragen twee ton droge stof per hectare per jaar op bouwland en één ton droge stof per hectare per jaar op grasland. Het is ook toegestaan om eens per twee jaar een dubbele dosering toe te passen. Verder mag zuiveringsslib alleen als meststof worden gebruikt nadat het een behandeling heeft ondergaan, zodat het onder normale omstandigheden bij blootstelling aan de lucht niet meer spontaan tot rotting overgaat, terwijl door de behandeling - ten gevolge waarvan diverse soorten micro-organismen afsterven - tevens de hygiënische kwaliteit ervan wordt verbeterd. Ook zijn er aanvullende voorwaarden opgenomen over de periode tussen bemesting en teelt van groente, fruit en voedergewassen om besmetting van deze producten met pathogenen te voorkomen. Tijdens perioden van beweiding mag geen zuiveringsslib worden uitgereden op grasland.

Het gebruik van zuiveringsslib in de landbouw is beperkt tot landbouwgronden die de toetsingsnormen voor zware metalen in de bodem niet overschrijden. Deze toetsingsnormen zijn opgenomen in Bijlage III van het Besluit Gebruik Meststoffen en worden berekend aan de hand van het organische stof- en lutumgehalte in de bodem (Tabel 2.1). De EU schrijft een bereik voor in toetsingswaarden voor (Richtlijn 86/278/EEG) en lidstaten zijn gemachtigd om scherpere normen te hanteren. Nederland heeft daar destijds voor gekozen.

In Tabel 2.2 zijn de toetsingswaarden voor zware metalen in de bodem berekend voor de zes meest voorkomende bodemtypen in Nederland (op basis van het gemiddelde gehalte aan organische stof en lutum per bodemtype). Nederland hanteert aanzienlijk lagere toetsingsnormen voor zware metalen in de bodem dan het voorgeschreven bereik zoals in de EU Richtlijn staat aangegeven. Vergelijking van de toetsingsnormen en de mediane gehalten aan zware metalen in de bodem (per bodemtype) laat zien dat de mediane samenstelling van Nederlandse gronden voldoet aan de toetsingsnorm. Bij een overschrijding is het gebruik van zuiveringsslib niet toegestaan.

Tabel 2.1 Toetsingswaarden voor de bodem bij het gebruik van zuiveringsslib (Wet Bodembescherming, Besluit Gebruik Meststoffen) ${ }^{1}$.

\begin{tabular}{ll} 
Element & Toetsingswaarde \\
$\mathrm{Cd}($ Cadmium) & ten hoogste $0,4+0,007(\mathrm{~L}+3 \mathrm{H}) \mathrm{mg} / \mathrm{kg} \mathrm{ds}$ \\
\hline $\mathrm{Cr}$ (Chroom) & ten hoogste $50+2 \mathrm{~L} \mathrm{mg} / \mathrm{kg} \mathrm{ds}$ \\
\hline $\mathrm{Cu}$ (Koper) & ten hoogste $15+0,6(\mathrm{~L}+\mathrm{H}) \mathrm{mg} / \mathrm{kg} \mathrm{ds}$ \\
\hline $\mathrm{Hg}($ Kwik) & ten hoogste $0,2+0,0017(2 \mathrm{~L}+\mathrm{H}) \mathrm{mg} / \mathrm{kg} \mathrm{ds}$ \\
\hline $\mathrm{Ni}($ Nikkel) & ten hoogste $10+\mathrm{L} \mathrm{mg} / \mathrm{kg} \mathrm{ds}$ \\
\hline $\mathrm{Pb}($ Lood) & ten hoogste $50+\mathrm{L}+\mathrm{H} \mathrm{mg} / \mathrm{kg} \mathrm{ds}$ \\
\hline $\mathrm{Zn}$ (Zink) & ten hoogste $50+1,5(2 \mathrm{~L}+\mathrm{H}) \mathrm{mg} / \mathrm{kg} \mathrm{ds}$ \\
\hline $\mathrm{As}$ (Arseen) & ten hoogste $15+0,4(\mathrm{~L}+\mathrm{H}) \mathrm{mg} / \mathrm{kg} \mathrm{ds}$ \\
\hline $\mathrm{L}=$ Lutumgehalte $(\%), \mathrm{H}=$ organische stofgehalte $(\%)$.
\end{tabular}


Tabel 2.2 Bodemspecifieke toetsingswaarden voor de bodem bij het gebruik van zuiveringsslib per grondsoort (Wet Bodembescherming, Besluit Gebruik Meststoffen) en mediane waarde voor zware metalen in de bodem.

\begin{tabular}{|c|c|c|c|c|c|c|c|c|c|c|}
\hline \multirow{2}{*}{ Grondsoort } & Cd & $\mathrm{Cr}$ & $\mathrm{Cu}$ & $\mathrm{Hg}$ & Ni & $\mathrm{Pb}$ & $\mathrm{Zn}$ & As & Lutum & O.S. \\
\hline & \multicolumn{8}{|c|}{ - } & $\%$ & $\%$ \\
\hline \multicolumn{11}{|c|}{ Grenswaarden bodem - Sewage Sludge Directive 86/278/EEG } \\
\hline n.v.t & $1-3$ & - & $50-140$ & $1-1,5$ & $30-75$ & $50-300$ & $150-300$ & - & & \\
\hline \multicolumn{11}{|c|}{ Toetsingswaarden - Meststoffenwet ${ }^{1}$} \\
\hline Zand & 0,6 & 63 & 22 & 0,2 & 17 & 61 & 76 & 19 & 7 & 4,7 \\
\hline Zand - kalkrijk & 0,4 & 54 & 17 & 0,2 & 12 & 53 & 57 & 16 & 2 & 1,1 \\
\hline Mariene klei & 0,7 & 104 & 35 & 0,3 & 37 & 82 & 139 & 28 & 27 & 5,4 \\
\hline Fluviatiele klei & 0,7 & 104 & 35 & 0,3 & 37 & 84 & 141 & 29 & 27 & 7,1 \\
\hline Löss & 0,6 & 80 & 26 & 0,3 & 25 & 69 & 100 & 22 & 15 & 3,6 \\
\hline Veen & 1,0 & 82 & 40 & 0,3 & 26 & 91 & 135 & 31 & 16 & 25 \\
\hline \multicolumn{11}{|c|}{ Mediane samenstelling - Nederland ${ }^{2}$} \\
\hline Zand & 0,2 & 21 & 7 & 0,04 & 1,6 & 17 & 19 & 3 & 7 & 4,7 \\
\hline Zand - kalkrijk & 0,2 & 20 & 7 & 0,04 & 1,6 & 17 & 19 & 3 & 2 & 1,1 \\
\hline Mariene klei & 0,3 & 72 & 15 & 0,07 & 24 & 30 & 77 & 15 & 27 & 5,4 \\
\hline Fluviatiele klei & 0,5 & 75 & 29 & 0,06 & 32 & 46 & 121 & 15 & 27 & 7,1 \\
\hline Löss & 0,8 & 77 & 13 & 0,07 & 18 & 35 & 97 & 10 & 15 & 3,6 \\
\hline Veen & 0,6 & 44 & 16 & 0,16 & 17 & 62 & 67 & 11 & 16 & 25 \\
\hline \multicolumn{11}{|c|}{$\begin{array}{l}1 \text { Bodemspecifieke toetsingswaarden berekend o.b.v. de toetsingswaarden (Tabel 2.1) en het gemiddelde organische stof- en lutumgehalte per } \\
\text { bodemtype in Nederlandse gronden. }\end{array}$} \\
\hline \multicolumn{11}{|c|}{$\begin{array}{l}2 \text { Mediane waarde voor zware metalen in de bovengrond van Nederlandse bodems uitgesplitst naar bodemtype. Bron: De geochemische atlas } \\
\text { van Nederland (Mol et al. 2010). }\end{array}$} \\
\hline
\end{tabular}

\section{Uitvoeringsbesluit Meststoffenwet}

Het Uitvoeringsbesluit Meststoffenwet stelt voorwaarden aan de vrije verhandeling, gebruiksnormen, vervoer en administratieve verplichtingen bij het gebruik van meststoffen in de landbouw. Voor zuiveringsslib wordt de voorwaarde gesteld dat pathogenen afdoende moeten zijn gedood.

Zuiveringsslib wordt geacht ten minste 50 gewichtsprocenten organische stof van de droge stof te bevatten of een pH-neutraliserende waarde van 25 (o.b.v. droge stof) te bevatten. Zuiveringsslib wordt geacht de maximale waarden voor zware metalen in slib niet te overschrijden. Verder is het niet toegestaan om zuiveringsslib onderling of met andere meststoffen te mengen (Uitvoeringsregeling Meststoffenwet).

De maximale gehalten aan zware metalen in zuiveringsslib, zoals opgenomen in Bijlage II van het Uitvoeringsbesluit Meststoffenwet, zijn opgenomen in Tabel 2.3. Een vergelijking met de gemiddelde samenstelling van zuiveringsslib laat zien dat de normen voor koper en zink fors worden overschreden. Voor meststoffen zijn eveneens normen voor organische microverontreinigingen opgenomen (Bijlage III, UBM). Deze zijn niet van toepassing op zuiveringsslib.

Een advies voor normen aan zware metalen in zuiveringsslib werd ontwikkeld vanaf 1980 door de Unie van Waterschappen (UvW, 1980; 1985) en later door de Technische Commissie Bodembescherming (TCB, 1991). Met de invoering van de Europese Verordening (86/278/EEG) ontstond de noodzaak om feitelijke normen op te stellen op basis van beschikbare adviezen, hetgeen resulteerde in het Besluit kwaliteit en gebruik overige organische meststoffen (BOOM) dat geldig werd in januari 1993. De normen voor de gehalten en het doseringsvoorschriften zijn gebaseerd op een balans tussen de aanvoer van zware metalen door slib en de afvoer door gewassen (i.e. voorzorgsprincipe). Bij het ontwikkelen van deze normen was duidelijk dat de normen zouden leiden tot uitsluiting van slib in de landbouw. De normen voor gehalten en doseringsvoorschrift uit het BOOM-besluit zijn later, met enkele aanpassingen voor waarde-gevende bestanddelen in slib en compost, overgenomen in het huidige Uitvoeringsbesluit Meststoffenwet en Wet Bodembescherming. 
Tabel 2.3 Maximale warden voor zware metalen in zuiveringsslib per $\mathrm{kg}$ droge stof zoals opgenomen in het Uitvoeringsbesluit Meststoffenwet (UBM) en gemiddelde samenstelling van Nederlands zuiveringsslib ${ }^{1}$.

\begin{tabular}{|c|c|c|}
\hline Parameter & Norm UBM & $\begin{array}{c}\text { Gemiddelde samenstelling communaal } \\
\text { zuiveringsslib }\end{array}$ \\
\hline $\mathrm{Cd}(\mathrm{mg} / \mathrm{kg})$ & 1,25 & 1.2 \\
\hline $\mathrm{Cu}(\mathrm{mg} / \mathrm{kg})$ & 75 & 409 \\
\hline $\mathrm{Hg}(\mathrm{mg} / \mathrm{kg})$ & 0,75 & 0.70 \\
\hline $\mathrm{Pb}(\mathrm{mg} / \mathrm{kg})$ & 100 & 107 \\
\hline $\mathrm{Zn}(\mathrm{mg} / \mathrm{kg})$ & 300 & 978 \\
\hline As $(\mathrm{mg} / \mathrm{kg})$ & 15 & 11 \\
\hline Doseringslimit (ton droge stof/ha/jaar) & $\begin{array}{l}\text { bouwland: } 2 \\
\text { grasland: } 1\end{array}$ & \\
\hline
\end{tabular}

\subsubsection{Andere EU-lidstaten}

Binnen het wettelijk kader van de Sewage Sludge Directive is het voor lidstaten toegestaan om de normen voor gehalten aan zware metalen in zuiveringsslib aan te scherpen of aanvullende criteria te introduceren. De verschillen in toetsingsnormen tussen diverse EU-lidstaten en de achtergronden van de ontwikkeling van deze toetsingsnormen zijn uitgebreid beschreven in eerdere literatuur (Ehlert et al. 2013, Milieu Ltd, 2008, European Communities, 2001). Tabel 2.4 toont een overzicht van toetsingsnormen voor gehalten aan zware metalen in een beperkt aantal EU-lidstaten. Tussen EUlidstaten zijn zeer grote verschillen in normen voor zware metalen in zuiveringsslib voor landbouwkundig gebruik. Ierland, Frankrijk en de Zuid-Europese landen (Italië, Spanje, Portugal, Griekenland) hebben normen die vergelijkbaar zijn met de normen in de Sewage Sludge Directive. In noordelijke landen worden over het algemeen lagere normen gehanteerd. Nederland hanteert de laagste normen, gevolgd door Vlaanderen, Zweden, Denemarken en Finland. Een aantal EU-lidstaten, waaronder Frankrijk, Italië, Luxemburg en Polen, stelt aanvullende criteria voor de concentraties aan pathogenen in slib. In andere landen wordt getracht de biologische kwaliteit te controleren door voorwaarden te stellen aan de minimale behandeling die slib moet ondergaan zonder dat er expliciete normen zijn voor pathogenen. Een aantal landen, waaronder Denemarken, Frankrijk, Duitsland en Zweden, heeft aanvullende normen voor organische verontreinigingen. Voor meer informatie over normen voor pathogenen en organische verontreinigingen in zuiveringsslib in EU-lidstaten wordt verwezen naar literatuur (Milieu Ltd, 2008). 
Tabel 2.4 Maximaal toegestane gehalten aan zware metalen in zuiveringsslib voor landbouwkundig gebruik in EU lidstaten in $\mathrm{mg} / \mathrm{kg}$ d.s (Milieu Ltd et al, 2008).

\begin{tabular}{|c|c|c|c|c|c|c|c|c|}
\hline Land & Cd & $\mathrm{Cr}$ & $\mathrm{Cu}$ & $\mathrm{Hg}$ & Ni & $\mathrm{Pb}$ & $\mathrm{Zn}$ & As \\
\hline Sewage Sludge & $20-40$ & - & $1000-1750$ & $16-25$ & $300-400$ & $750-1200$ & $2500-4000$ & - \\
\hline \multicolumn{9}{|c|}{ Directive-86/278/EEC } \\
\hline Duitsland & 2 & 80 & 600 & 1.4 & 60 & 100 & 1500 & - \\
\hline Engeland $^{2}$ & $20-40$ & - & $1000-1750$ & $16-25$ & $300-400$ & $750-1200$ & $2500-4000$ & - \\
\hline België-Vlaanderen & 6 & 250 & 375 & 5 & 50 & 300 & 900 & 150 \\
\hline België-Wallonie & 10 & 500 & 600 & 10 & 100 & 500 & 2000 & - \\
\hline Frankrijk & 20 & 1000 & 1000 & 10 & 200 & 800 & 3000 & - \\
\hline Zweden & 2 & 100 & 600 & 2.5 & 50 & 100 & 800 & - \\
\hline Spanje $^{3}$ & $20-40$ & $1000-1750$ & $1000-1750$ & $16-25$ & $300-400$ & $750-1200$ & $2500-4000$ & \\
\hline Finland & 1.5 & 300 & 600 & 1 & 100 & 100 & 1500 & \\
\hline Slib-NL ${ }^{4}$ & 1.2 & 41 & 409 & 0.7 & 28 & 107 & 978 & 11 \\
\hline
\end{tabular}

1 In een aantal landen gelden aanvullende criteria voor pathogenen en/of organische verontreinigingen.

2 Geen aanscherping van gehalten, maar wel aanscherping van totale vracht aan zware metalen.

3 Laagste waarden voor bodems met $\mathrm{pH}<7.0$, hoogste waarden voor bodems met $\mathrm{pH}>7.0$.

4 Gemiddelde samenstelling van zuiveringsslib in Nederland (CBS, data 2013).

\subsection{Landbouwkundig gebruik van zuiveringsslib in Europese lidstaten}

In 2012 werd 50\% van het zuiveringsslib in Europa gebruikt in de landbouw en nog eens 10\% voor de productie van compost, in de landschapsbouw of verwerkt tot een andere vorm van hergebruik (Eurostat, data 2012). Tussen Europese lidstaten zijn er zeer grote verschillen in de wijze van slibverwerking en afzet (Figuur 2.1). Enerzijds zijn er EU-lidstaten waar het landbouwkundig gebruik van zuiveringsslib zeer gangbaar is (o.a. Engeland, Spanje, Frankrijk, Zweden), anderzijds zijn er ook landen - waaronder Nederland, Zwitserland en Malta en België - waar zuiveringsslib (vrijwel) niet in de landbouw wordt gebruikt.

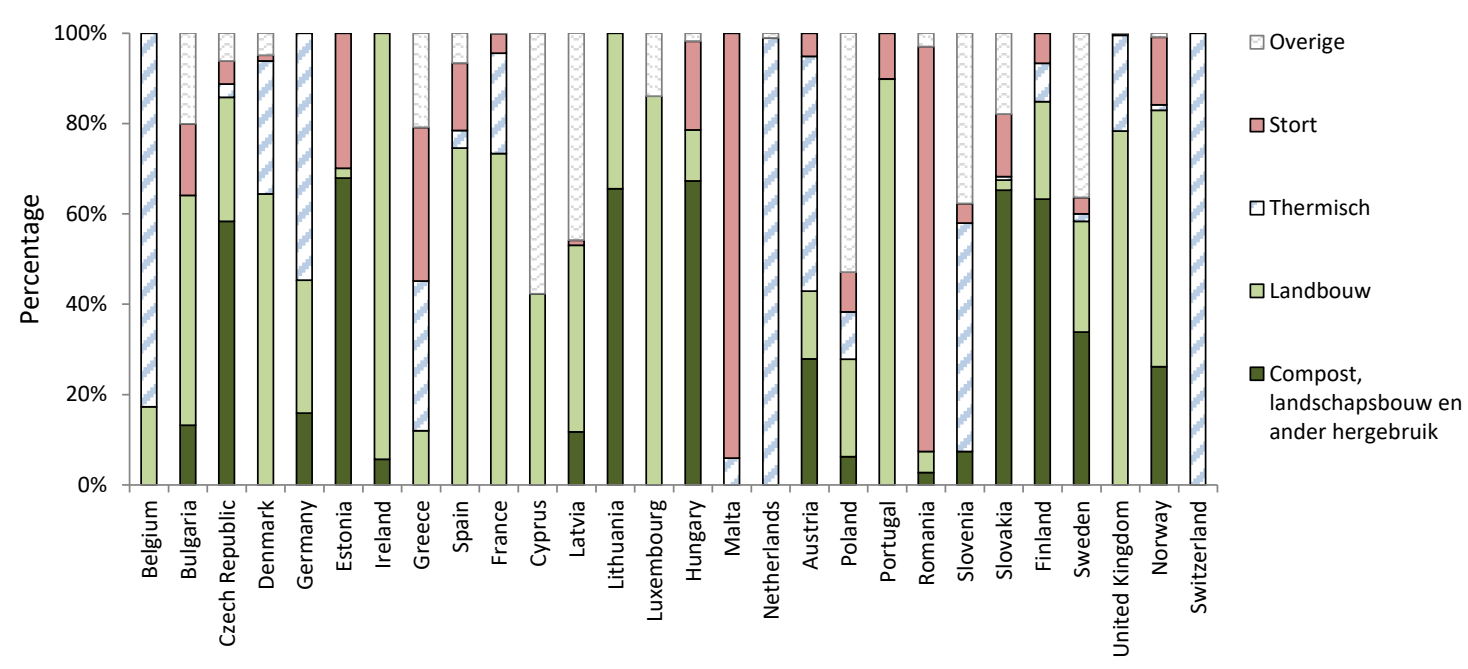

Figuur 2.1 Afzet van communaal zuiveringsslib in EU-lidstaten, Noorwegen en Zweden naar landbouw, compost en thermische verwerkingsinstallaties (Data: Eurostat voor het jaar 2012). 
De maatschappelijke weerstand tegen het gebruik van slib in de landbouw is ontstaan in de jaren tachtig. Deze discussies werden ingegeven door twijfel over de voedselveiligheid en incidenten met het gebruik van zuiveringsslib in de landbouw (Europese Commissie, 2001a). Daarnaast ontstond er in gebieden met intensieve veehouderij een overschot aan dierlijke mest waardoor de vraag naar zuiveringsslib als meststof afnam. Dit is een van de redenen voor het verschillend verlopen van de discussie over landbouwkundig gebruik van slib in verschillende EU-landen. In Nederland en Vlaanderen is de discussie gestopt na het besluit om slib niet meer in de landbouw te gebruiken. In andere landen, waaronder Zweden, Denemarken en Engeland, is de discussie afgenomen na invoering van striktere voorwaarden voor het gebruik van slib in de landbouw. In Zuid-Europese landen is er weinig debat geweest. Er zijn grote verschillen in de wijze waarop EU-lidstaten hebben gereageerd op de maatschappelijke discussies rondom het gebruik van zuiveringsslib. Dit wordt hieronder voor een aantal landen kort toegelicht.

\section{Duitsland}

In Duitsland wordt jaarlijks 1,8 miljoen ton (droge stof) zuiveringsslib geproduceerd waarvan 55\% thermisch wordt verwerkt en $45 \%$ wordt afgezet in de landbouw. Afzet in de landbouw vindt grotendeels plaats in de vorm van slib (64\%) en verder als slibcompost (36\%) (Eurostat, 2012). Tussen deelstaten zijn er grote verschillen in slib-afzetroutes, wat mede wordt veroorzaakt door het feit dat de voorwaarden voor gebruik van slib in landbouw per deelstaat kunnen verschillen.

In Duitsland staat het gebruik van zuiveringsslib in de landbouw sinds de jaren negentig ter discussie. Deze discussie spitst zich zowel toe op metalen alsook op onduidelijke verontreinigingen en antibioticaresistentie. Mede door het slechte imago van zuiveringsslib is de afzet van zuiveringsslib naar de landbouw in de afgelopen decennia teruggelopen naar 45\%. Anno 2015 heeft de Duitse overheid een voorstel geformuleerd om met ingang van 2025 de afzet van zuiveringsslib naar de landbouw te beëindigen (AbfKlärV, 2015) en de terugwinning van fosfaat uit slib of verbrandingsassen verplicht te stellen. Aanleiding hiervoor is de wens om fosfaat terug te winnen om zo het gebruik en de afhankelijkheid van fosfaatmijnen terug te dringen.

\section{Engeland}

In Engeland wordt circa $80 \%$ van het zuiveringsslib afgezet in de landbouw. Engeland hanteert de maximaal toegestane normen voor zware metalen (Sewage Sludge Directive). Sinds de negentig staat het gebruik van zuiveringsslib in de landbouw ter discussie. Deze discussie werd voornamelijk gedreven vanuit retailers die zorgen hadden over de voedselveiligheid bij het gebruik van zuiveringsslib als meststof. Deze discussie heeft ertoe geleid dat er in 1989 een vrijwillige overeenkomst is ingevoerd tussen UK Water en het British Retail Consortium. Deze afspraken zijn vastgelegd in de Safe Sludge Matrix (ADAS, 2001) en vormt een aanvulling op de eerder ingevoerde Code of practice for agriculture use of sewage sludge. In beide overeenkomsten zijn afspraken gemaakt over de behandeling die zuiveringsslib moet ondergaan en over het gebruik van zuiveringsslib voor het telen van groenten en gewassen. Deze afspraken zijn er met name op gericht om verspreiding van pathogenen via slib te voorkomen. Niet-behandeld slib mag volgens de overeenkomst niet meer worden toegepast in de landbouw. Conventioneel behandeld slib dat een behandeling heeft ondergaan waarbij gehalten aan pathogenen met $99 \%$ is afgenomen (vergisting, composteren, stabilisatie met kalk) mag worden toegepast in de akkerbouw voor productie van graan en veevoer en op grasland. Enhanced treated sludge, dat een 'advanced treatment' heeft ondergaan waarbij $99.9999 \%$ van de pathogenen is afgedood, mag in alle sectoren gebruikt worden, waaronder voor de teelt van groenten. In de overeenkomst zijn geen aanvullende criteria voor zware metalen of organische contaminanten opgenomen.

\section{Denemarken}

In Denemarken is de discussie rondom landbouwkundig gebruik van zuiveringsslib gestopt na de invoering van strengere normen voor zware metalen en aanvullende normen voor een aantal organische microverontreinigingen (PAH, LAS, DEHP, NPE). Denemarken hanteert vrij ruime normen voor koper $(1000 \mathrm{mg} / \mathrm{kg})$ en zink $(4000 \mathrm{mg} / \mathrm{kg})$, maar zeer strikte normen voor de overige zware metalen. Hiermee hanteert Denemarken, na Nederland, de striktste normen voor zware metalen in zuiveringsslib binnen de EU. De algemene perceptie is dat deze criteria de kwaliteit van zuiveringsslib voldoende garanderen en de verwachting is dat de afzet naar de landbouw (60\% van de slibproductie) stabiel blijft (European Commission, 2001a). 


\section{Zweden}

Zweden heeft de doelstelling om in 2015 minimaal 60\% van het fosfaat uit afvalwater te hergebruiken in de landbouw en ziet het gebruik van zuiveringsslib in de landbouw als een van de efficiëntste wijzen van hergebruik van fosfaat (SEPA, 2005). Daarom heeft de overheid het landbouwkundig gebruik van zuiveringsslib actief gepromoot. De afzet van zuiveringsslib naar de landbouw is de afgelopen tien jaar toegenomen van $8 \%$ (2006) naar 24\% (2012). Daarnaast wordt 32\% van het slib afgezet in de categorie compost, landschapsbouw en overig hergebruik (Eurostat).

Het zeer lage gebruik van slib in de landbouw in het verleden was het gevolg van een zeer slecht imago van slib door een incident met brandvertragers en angst voor verspreiding van organische contaminanten. Door invoering van een certificeringssysteem, ReVaq, is het imago van zuiveringsslib verbeterd en het gebruik van slib in de landbouw gestegen. Het doel van de ReVaq (ReVaq, 2015) is om de kwaliteit van zuiveringsslib te verbeteren door een brongerichte aanpak van verontreinigen. Daarnaast spelen transparantie, openheid en traceerbaarheid een belangrijke rol in de ReVaqcertificering. Zo hebben stakeholders inzicht in kwaliteits- en procesgegevens. De kwaliteit van het slibproduct wordt systematisch gemonitord en het product is traceerbaar. Gecertificeerde waterschappen committeren zich aan deze doelen, wat bijvoorbeeld inhoudt dat ze actie ondernemen om (industriële) bronnen van verontreinigen op te sporen en te verminderen. In 2014 was ongeveer de helft van de RWZI's in Zweden voorzien van deze certificering (SEPA, 2014). Daarnaast vindt onderzoek plaats naar mogelijke milieueffecten van het gebruik van zuiveringsslib in de landbouw. Met deze aanpak tracht de overheid een veilig en duurzaam gebruik van zuiveringsslib in de landbouw te stimuleren.

\subsection{Europa's ambitie voor het sluiten van de fosfaatkringloop}

\section{Europese Commissie}

Het belang van een duurzaam gebruik van fosfaat in Europa werd door de Europese Commissie voor het eerst erkend in 2011 in 'The Roadmap to a Resource Efficient Europe' (COM(2011)-257).

Daaropvolgend werd door de EC een consultatie uitgeschreven over een duurzaam gebruik van fosfaat (COM(2013)-517). Uit de consultatie blijkt dat het sluiten van de P-kringloop wenselijk en haalbaar is. De belangrijkste drijfveren voor het sluiten van de fosfaatkringloop zijn het garanderen van toekomstige beschikbaarheid van fosfaat en het terugdringen van Europa's afhankelijkheid van externe (niet-hernieuwbare) fosfaatmijnen in politiek onstabiele regio's. Hergebruik van fosfaat uit afvalstromen wordt tevens gezien als een mogelijkheid om verdere belasting van landbouwbodems met cadmium te voorkomen, waarbij de aanwezigheid van andere contaminanten in herwonnen fosfaten wel een aandachtspunt is. Verder kwam uit de consultatie naar voren dat hergebruik van fosfaat vraagt om het creëren van geschikte marktcondities. Naar aanleiding van de consultatie heeft de Europese Commissie in 2014 besloten om fosfaat op de lijst van 'Critical Raw Materials' te plaatsen (COM(2014)-297). Op dit moment tracht de Europese Commissie de ontwikkeling van de circulaire economie te stimuleren door de marktcondities te verbeteren voor meststoffen die op dit moment een afval-status hebben. Hiervoor is een pakket aan maatregelen gelanceerd (Circular Economy Package, $\operatorname{COM}(2015)$-614) waaronder de nieuwe EU-Meststoffenverordening, die de handel in meststoffen uit o.a. biowaste eenvoudiger moet maken.

\section{Fosfaat-stromen in Europa}

Figuur 2.2 toont de fosfaatstromen in Europa die zijn berekend op basis van beschikbare datasets uit 2005 voor de afzonderlijke lidstaten (Van Dijk et al. 2015). Hieruit blijkt dat Europa jaarlijks 1399 kton fosfor importeert in de vorm van (hoofdzakelijk minerale) meststoffen. Jaarlijks gaat 1217 kton fosfor definitief verloren door onder andere verliezen vanuit huishoudens (54\%), slachtafval (18\%) en voedingsmiddelenindustrie (10\%). Fosfaat uit zuiveringsslib van communale waterzuiveringen is verantwoordelijk voor 20\% (230 kton) van het totale fosforverlies in Europa. In 2005 ging 60\% van het fosfaat uit communaal afvalwater verloren door o.a. het gebruik van P-rijke verbrandingsassen in asfalt. De overige $40 \%$ werd hergebruikt in de landbouw. De totale hoeveelheid fosfaat in communaal zuiveringsslib (230 kton) is voldoende om 16\% van Europa's import aan fosfaatmeststoffen te dekken (1000 kton, data Eurostat 2011). Zuiveringsslib vormt daarmee een grote bron van fosfaat, die 
bovendien relatief eenvoudig bruikbaar of herwinbaar is in vergelijking met andere meer diffuse verliesposten van fosfaat. Naar verwachting zal zuiveringsslib zodoende een belangrijke rol gaan spelen in het realiseren van Europa's ambities om fosfaat hergebruik te stimuleren.

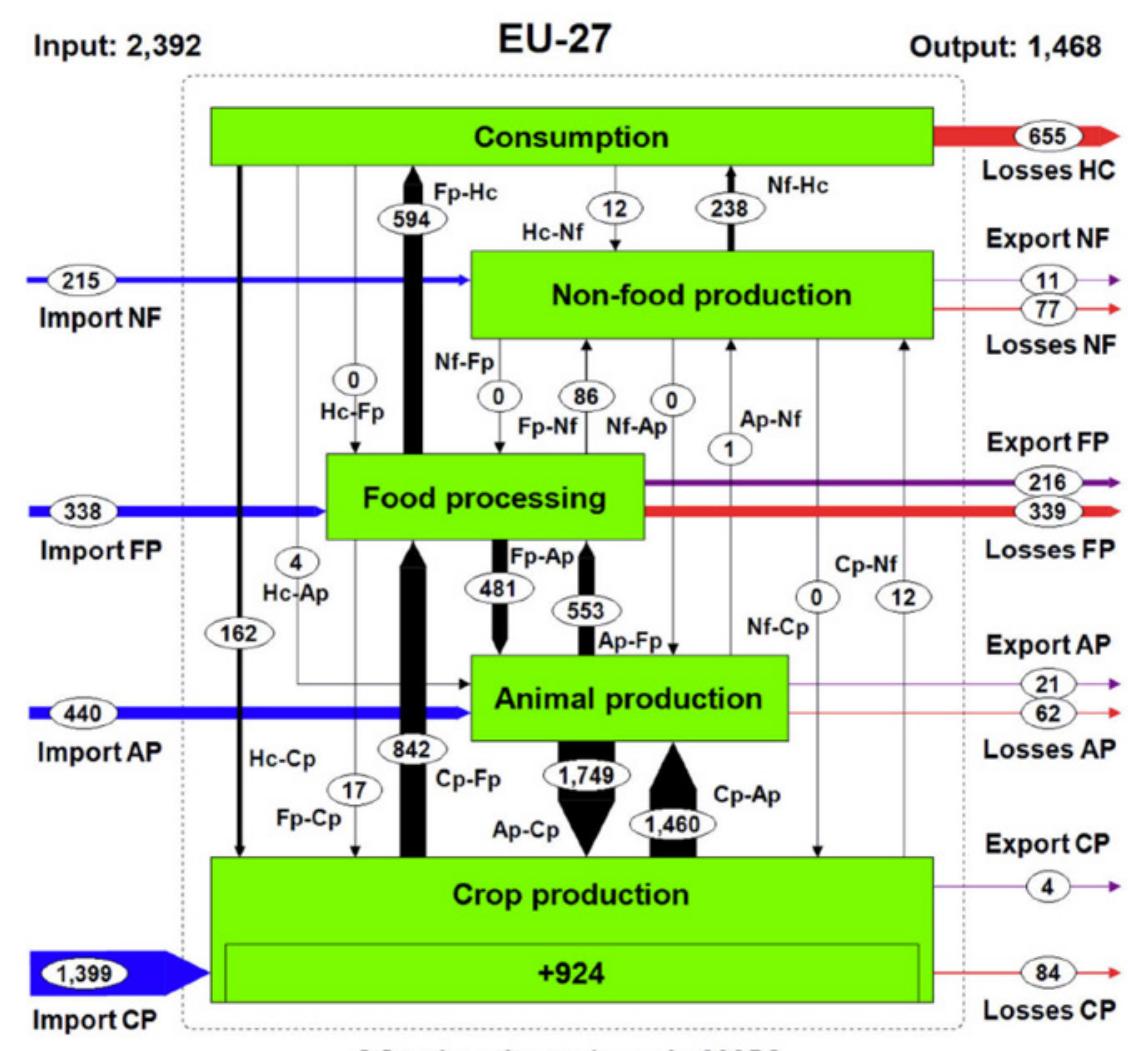

[ Gg phosphorus / year in 2005]

Figuur 2.2 Fosfaatstromen in Europa overgenomen van Van Dijk et al. (2015). Verliezen vanuit household consumption (losses HC) zijn voor 35\% te verklaren door verliezen door het niethergebruiken van fosfaat uit communaal zuiveringsslib.

\section{Maatregelen door EU-lidstaten}

Een aantal EU-lidstaten heeft zelf al stappen ondernomen om hergebruik en terugwinning van fosfaat te verplichten of te stimuleren. In Nederland zijn herwonnen fosfaten sinds 2014 als aparte categorie opgenomen in het Uitvoeringsbesluit Meststoffenwet (UBM, 2016) waardoor de handel in en het landbouwkundig gebruik van herwonnen fosfaten uit o.a. communaal afvalwater onder voorwaarden wordt toegestaan.

Zwitserland is het eerste land dat fosfaat terugwinning uit afvalwater en slachtafval verplicht stelt (Zwitserland, 2016). De verplichting is ingegaan in 2016 met een overgangstermijn van tien jaar. De landbouwkundige aanwending van zuiveringsslib is in Zwitserland sinds 2006 verboden en zuiveringsslib wordt sindsdien uitsluitend thermisch verwerkt. Het terugwinnen van fosfaat vindt dan ook plaats door terugwinning uit verbrandingsassen.

Duitsland is de tweede EU-lidstaat die de terugwinning van fosfaat uit zuiveringsslib verplicht stelt. Naar verwachting treedt deze wet in 2018 in werking met een overgangstijd van 10 jaar (AbfKlärV, 2015). Met deze wet wordt de afzet van zuiveringsslib naar de landbouw verboden (met uitzondering van kleine RWZI's) en wordt het terugwinnen van fosfaat uit slib verplicht gesteld. Er geldt een minimale recovery van $50 \%$ bij terugwinning van fosfaat uit slib op de RWZI een minimale recovery van $80 \%$ bij terugwinning uit verbrandingsassen. Aanleiding tot dit besluit is de decennialange discussie over milieurisico's bij landbouwkundig gebruik van zuiveringsslib en de ambitie de afhankelijkheid van externe fosfaatmijnen te verminderen. 
Zweden heeft de ambitie om nutriënten uit zuiveringsslib optimaal te benutten. Zweden heeft daarvoor de doelstelling geformuleerd om minimaal $50 \%$ van het fosfaat uit communaal afvalwater in de landbouw inclusief bosbouw te hergebruiken (SEPA, 2005). In tegenstelling tot Zwitserland en Duitsland wordt in de directe landbouwkundig aanwending van zuiveringsslib in Zweden wel gezien als een vorm van nuttig gebruik van zuiveringsslib. De Zweedse overheid promoot en stimuleert het gebruik van zuiveringsslib in de landbouw actief. Daarnaast is een kwaliteitskeurmerk voor RWZI's geïntroduceerd (REVAQ) om de kwaliteit en traceerbaarheid van zuiveringsslib te garanderen. Deze maatregelen hebben ertoe geleid dat het landbouwkundig gebruik van zuiveringsslib in Zweden in de laatste tien jaar sterk is toegenomen.

\subsection{Nieuwe Europese regelgeving voor meststoffen}

Een nieuwe ontwikkeling is dat op 17 maart 2016 de Europese Commissie een pakket maatregelen heeft aangekondigd die een transitie teweegbrengt van een lineaire economie naar een circulaire economie. Een onderdeel daarvan is een nieuwe meststoffenverordening, waardoor hernieuwbare hulpbronnen hergebruikt kunnen worden. Afvalstoffen die aan de bepalingen van deze nieuwe verordening voldoen, verliezen daardoor hun afvalstatus en kunnen als meststof met CE-markering vrij worden verhandeld. Voorheen bestond alleen voor anorganische meststoffen ('kunstmest') een mogelijkheid tot het verkrijgen van een CE-markering. In de toekomst kunnen ook organische meststoffen, bodemverbeteraars en biostumultoren (humuszuren e.d.) onder voorwaarden van de EUMeststoffenverordening vrij in Europa verhandeld worden. Zuiveringsslib wordt echter expliciet uitgesloten als meststof. Op Europees niveau hebben zuiveringsslib en producten daaruit (slibcompost, struviet, biochar e.d.) een afvalstatus, waardoor deze zijn uitgesloten om vrij verhandeld te kunnen worden als meststof die het label 'EG-meststof' voert. Nationaal kunnen deze bemestingsproducten wel in het vrije handelsverkeer worden gebracht.

Zuiveringsslib en producten uit slib zijn vooralsnog uitgesloten als meststof. Echter, in opdracht van de Europese Commissie voert het Joint Research Centre op dit moment een studie (in werkgroep verband (STRUBIAS) uit naar mogelijke End of Waste-criteria voor producten uit slib, zijnde struviet, biochar of verbrandingsassen. In het huidige ontwerp voor deze studie zijn verbrandingsassen, biochar en struviet (van o.a. zuiveringsslib) in beeld (Europese Commissie, 2016a). Het is onduidelijk of hydrochar (i.e. het product na hydrothermale carbonisatie) eveneens onder de definitie van biochar valt. Of Europees beleidsmatige afstemming leidt tot een opname van een van deze categorieën, wordt pas na 2018 duidelijk na inwerkingtreding van de nieuwe Europese meststoffenverordening. Eind 2018 wordt bekend welke criteria aanbevolen worden waarna beleidsafweging en formuleren van bestandsdeelcategorieën voor struviet, biochar en/of assen volgt en aanpassing van de verordening mogelijk wordt. Zuiveringsslib en slibcompost zijn daarentegen nu nog explicit uitgesloten als meststof en vormen nog geen onderdeel van studies voor het afleiden van einde-afvalstatuscriteria.

Tabel 2.5 Ontwerpnormen voor organische meststoffen en bodemverbeteraars in het ontwerpvoorstel voor de nieuwe EU-Meststoffenverordening ${ }^{1}$, inclusief voorstel voor wijziging ${ }^{2}$.

\begin{tabular}{|c|c|c|}
\hline \multicolumn{2}{|r|}{ Parameter } & $\begin{array}{l}\text { Ontwerpnorm } \\
\text { (mg/kg) }\end{array}$ \\
\hline & $\mathrm{Cd}$ & 1.5 \\
\hline & $\mathrm{Hg}$ & 1 \\
\hline & $\mathrm{Ni}$ & 50 \\
\hline & $\mathrm{Zn}$ & $(1500)^{2}$ \\
\hline & E.coli of Enterococcaceae & $<1000 \mathrm{kve} / \mathrm{gram}$ product \\
\hline & Salmonella. & Afwezig in 25 gram bemestingsproduct \\
\hline \multicolumn{3}{|c|}{$\begin{array}{l}1 \text { COM(2016)157, zuiveringsslib en slibcompost zijn expliciet uitgesloten als meststof. Het JRC voert een studie uit naar EoW criteria voor } \\
\text { producten (biochar, struviet, verbrandingassen) uit o.a. zuiveringsslib (versie } 17 \text { maart 2016). }\end{array}$} \\
\hline \multicolumn{3}{|c|}{$\begin{array}{l}2 \text { In het voorstel van } 17 \text { maart } 2017 \text { zijn geen normen voorzien voor koper en zink. Echter, dit staat nog ter discussie en er zijn vanuit lidstaten } \\
\text { voorstellen gedaan om koper en zink gehalten in meststoffen alsnog te reguleren met een norm van respectievelijk } 600 \text { en } 1500 \mathrm{mg} / \mathrm{kg} \text {. }\end{array}$} \\
\hline
\end{tabular}


De Europese Commissie heeft op 17 maart 2016 een ontwerpvoorstel voor de nieuwe meststoffenverordening gepubliceerd (COM (2016)-157), waarin onder meer maximaal toelaatbare gehalten aan contaminanten en pathogenen zijn opgenomen. Tabel 2.5 toont de ontwerpnormen voor zware metalen en pathogenen in organische meststoffen en bodemverbeteraars. De criteria voor maximaal toelaatbare gehalten aan contaminanten zijn zeer ruim, evenals als de samenstellingseisen voor de producten. Voor cadmium, nikkel, lood en kwik zijn wel normen opgesteld, evenals voor salmonella en $E$ coli of Enterococcaceae. Ten tijde van het schrijven van dit rapport zijn de normen al enigszins gewijzigd. Er zijn voorstellen gedaan voor het opnemen van normen voor koper en zink met een norm van respectievelijk 600 en $1500 \mathrm{mg} / \mathrm{kg}$. Deze, en andere voorgestelde wijzigingen, worden nu door de lidstaten bestudeerd.

\section{$2.5 \quad$ Conclusies}

- Tussen EU-lidstaten zijn er zeer grote verschillen in de gehanteerde normen voor zware metalen in zuiveringsslib. Van alle EU-lidstaten hanteert Nederland de striktste normen voor zware metalen in zuiveringsslib bij landbouwkundige toepassing.

- Gemiddeld word $60 \%$ van het in de EU geproduceerde slib gebruikt in de landbouw, compost of bosbouw (data 2012). In enkele lidstaten (Nederland, Zwitserland en Malta en België) wordt (vrijwel) geen slib in de landbouw toegepast. Duitsland is voornemens om de landbouwkundige toepassing van zuiveringsslib vanaf 2018 te verbieden. In Zweden wordt het landbouwkundig gebruik van slib juist gepromoot en gezien als de effectiefste methode voor hergebruik van nutriënten uit slib.

- Tussen EU-lidstaten zijn er zeer grote verschillen in de mate waarin slib in de landbouw wordt afgezet en in de mate van maatschappelijke weerstand tegen het gebruik van zuiveringsslib in de landbouw. De introductie van een betrouwbaar kwaliteitssysteem met aanvullende criteria (pathogenen) en controle aan de bron wordt veelal gezien als succesvolle maatregel om de kwaliteit te waarborgen en het 'wegmengen' van verontreinigingen te voorkomen.

- De Europese Commissie heeft de ambitie om Europa's afhankelijkheid van externe fosfaatbronnen terug te dringen. Terugwinning van fosfaat uit communaal afvalwater speelt een belangrijke rol bij het realiseren van deze ambities vanwege de grote omvang van deze stroom (20\% van het totale $\mathrm{P}$ verlies in de EU) en de goede mogelijkheden tot fosfaat-terugwinning. Verplichte fosfaatterugwinning uit zuiveringsslib is vooralsnog niet voorzien. Zwitserland en Duitsland hebben op nationaal niveau een verplichting tot fosfaatterugwinning uit zuiveringsslib ingevoerd.

- Met de invoering van de nieuwe meststoffenverordening stimuleert de Europese Commissie het gebruik van producten met een afvalstatus als meststof. Voor deze meststoffen worden zeer ruime normen voor zware metalen gehanteerd. Zuiveringsslib is echter expliciet uitgesloten als meststof. Of producten uit zuiveringsslib (herwonnen fosfaten, biochar, assen) onder voorwaarden opgenomen als EG-meststof verhandeld mogen worden, wordt in 2018 duidelijk. Aanpassing van Europese regelgeving zal pas na 2018 kunnen plaatsvinden. 


\section{Landbouwkundige waarde van slib}

\section{$3.1 \quad$ Inleiding}

Nederlandse waterschappen produceren jaarlijks 1269 kton zuiveringsslib uit communaal afvalwater met daarin 11 kton fosfor $(P)$ en 18 kton stikstof (N) (Tabel 3.1). De afzetmogelijkheden voor slib in de landbouw hangen samen met de mogelijkheden om slib te verwerken tot een organische meststof of bodemverbeteraar die qua fysisch-chemische samenstelling voldoet aan de vraag van de markt. Organische meststoffen vormen primair een bron van nutriënten. Organische bodemverbeteraars kenmerken zich door een laag nutriëntengehalte en vormen primair een bron van organische stof. De Nederlandse agrarische sector kampt met een overschot aan nutriënten waardoor dierlijke mest en organische meststoffen met geld toe moeten worden afgezet. De aanwezige nutriënten $(N, P)$ in slib en slibproducten moeten zodoende concurreren met de afzet van nutriëntrijke dierlijke mest. Het gehalte aan nutriënten is daarmee bepalend voor de positionering en afzetmogelijkheden van slib en slibproducten. In dit hoofdstuk worden de perspectieven voor de afzet van slib in de Nederlandse landbouw beoordeeld. Afzet naar andere sectoren, waaronder de potgrondindustrie en wegenbouw, is buiten beschouwing gelaten, omdat reeds uit eerder onderzoek is gebleken dat hier geen perspectieven liggen (IJzerman et al. 2014).

\subsection{Productie en samenstelling slib}

De landbouwkundige waarde van zuiveringsslib wordt hoofdzakelijk bepaald door de gehalten aan fosfaat, stikstof en organische stof en de verhoudingen tussen deze waarde-gevende bestanddelen. Zuiveringsslib kenmerkt zich, ten opzichte van dierlijke mest, door een hoog fosfaatgehalte (Tabel 3.2). Fosfor is primair een waarde-gevend bestanddeel; echter, door het overschot aan P in de Nederlandse landbouw is de economische waarde van een organische fosfaatmeststof negatief. Stikstof en organische stof zijn waarde-verhogende eigenschappen. Kalium- en magnesiumgehalten zijn vrij laag en dragen zodoende niet substantieel bij aan de economische waarde van slib als meststof. Het ijzergehalte varieert sterk tussen locaties. Bij een hoog ijzergehalte zal het fosfaat in het slib minder beschikbaar zijn voor plantopname, wat nadelig is bij toepassing van slib als meststof, omdat de totale fosfaat-gift door wetgeving wordt beperkt.

Tabel 3.1 Totale productie van communaal zuiveringsslib in Nederland (CBS, 2014).

\begin{tabular}{lcc} 
Parameter & $\begin{array}{c}\text { Productie } \\
\text { (kton/jaar) }\end{array}$ \\
Slib & 1269 \\
\hline Droge stof & 315 & 11 \\
\hline Fosfor $(P)$ & 25 \\
\hline Fosfaat $\left(\mathrm{P}_{2} \mathrm{O}_{5}\right)$ & 18 & 18 \\
\hline Stikstof $(\mathrm{N})$ & 25 \\
\hline
\end{tabular}

Tabel 3.2 Gemiddelde samenstelling van slibkoek en biogranulaat.

\begin{tabular}{|c|c|c|c|c|c|c|c|c|c|c|}
\hline Product & $\begin{array}{l}\text { D.S. } \\
(\%)\end{array}$ & $\begin{array}{l}\text { O.S. } \\
\text { (\% d.s.) }\end{array}$ & $\mathbf{P}$ & $\mathrm{P}_{2} \mathrm{O}_{5}$ & N-tot & $\begin{array}{l}\mathrm{K}_{2} \mathrm{O} \\
-\mathrm{g} / \mathrm{k}\end{array}$ & Mg & Fe & $\begin{array}{l}\text { pH } \\
(-)\end{array}$ & $\begin{array}{l}\mathrm{Ec} \\
\mathrm{ms} / \mathrm{cm}\end{array}$ \\
\hline Slib - data CBS $^{1}$ & 25 & 68 & 34 & 78 & 56 & - & - & - & - & - \\
\hline Biogranulaat $^{3}$ & 62 & 51 & 35 & 80 & 37 & 7,0 & 9,4 & 45 & 7,7 & 9,3 \\
\hline
\end{tabular}

1 Gemiddelde samenstelling slib bij afzet in Nederland, data 2014 (CBS).

2 Gemiddelde samenstelling ontwaterd slib (gemiddelde van zes slibmonsters).

3 Gecomposteerd slib, product van GMB BioEnergie, locatie Zutphen. 


\section{Biogranulaat}

GMB-BioEnergie verwerkt jaarlijks 260 kton slib afkomstig van zeven waterschappen tot biogranulaat door middel van tunnelcompostering (in Zutphen en Tiel). Ontwaterd slib, met een drogestofgehalte van $\pm 25 \%$, wordt hierbij gecomposteerd tot een eindproduct met $65 \%$ droge stof. De gemiddelde verblijftijd bedraagt 70 dagen en de temperatuur loopt tijdens het composteren op tot 65 à $70{ }^{\circ} \mathrm{C}$. De samenstelling van het biogranulaat wijkt op een aantal punten af van de samenstelling van slib. Tijdens het composteringsproces vindt vervluchtiging van ammoniak plaats waardoor het $\mathrm{N}$-gehalte van het biogranulaat $(37 \mathrm{~g} / \mathrm{kg}$ ) lager is dan van slib. De vrijkomende ammoniak wordt door GMB teruggewonnen in de vorm van ammoniumsulfaat, dat als grondstof voor meststof wordt afgezet. Verder daalt het organische stofgehalte van 68 tot $51 \%$ doordat afbreekbare organische componenten worden afgebroken. De resterende organische fractie is biologisch stabiel en zal dus bijdragen aan de opbouw van organische stof in de bodem. De EC waarde van biogranulaat $(9,3 \mathrm{mS} / \mathrm{cm})$ is aanzienlijk hoger dan die van GFT-compost (2,2 mS/cm, BVOR, 2016). Hoge zoutconcentraties zijn vooral problematisch bij toepassing in potgrond en dergelijke. Bij toepassing in de landbouw vormt een hoog zoutgehalte echter geen beperking, mits het tijdstip van bemesting juist wordt gekozen.

\subsection{Markt voor meststoffen en bodemverbeteraars}

\subsubsection{Gebruiksnormen}

De afzetmogelijkheden voor meststoffen worden thans sterk bepaald door de gebruiksnormen voor fosfaat en, in mindere mate, door gebruiksnormen voor stikstof. De gebruiksnormen geven de maximale hoeveelheden stikstof en fosfaat aan die gebruikt mogen worden voor de bemesting van gewassen. Alle meststoffen tellen mee bij het bepalen van de plaatsingsruimte van fosfaat op een bedrijf.

Er gelden drie soorten gebruiksnormen voor resp. fosfaat, totaal stikstof en stikstof uit dierlijke mest:

1. Fosfaatgebruiksnorm: De hoogte van de fosfaatbemesting is in Nederland door regelgeving beperkt om het risico op belasting van het oppervlaktewater met fosfaat te verlagen. Sinds 2015 geldt dat de fosfaatbemesting gelijk is gesteld aan de fosfaatafvoer (evenwichtsbemesting). Dit geldt voor de fosfaattoestand "neutraal". Bij een hoge toestand is de gebruiksnorm lager teneinde in de bodem opgebouwde fosfaatvoorraden af te bouwen en daarmee het risico op fosfaatuitspoeling te verlagen; bij een lage toestand is deze hoger teneinde suboptimale bemesting van landbouwgewassen te voorkomen (Tabel 3.3). De fosfaatgebruiksnorm is in de regel de beperkende factor bij de dosering van dierlijke mest.

2. Stikstofgebruiksnorm: De totale hoeveelheid stikstof die per hectare per jaar gebruikt mag worden. Van dierlijke mest en andere organische meststoffen telt daarbij alleen de werkzame stikstof mee. De stikstofgebruiksnorm is afhankelijk van het gewas dat geteeld wordt en de grondsoort.

3. Gebruiksnorm voor dierlijke mest: De hoeveelheid stikstof uit dierlijke mest die per hectare per jaar gebruikt mag worden. De gebruiksnorm is 170 kilo stikstof per hectare, maar als aan verschillende voorwaarden wordt voldaan, mag een bedrijf op grasland voor graasdierenmest een norm van 230 of 250 kilo stikstof per hectare gebruiken afhankelijk van de regio (derogatie). Stikstof betreft het totaalgehalte. De belangrijkste voorwaarden zijn dat het bedrijf bestaat uit minimaal $80 \%$ grasland en dat er bodemanalyses uitgevoerd zijn.

Tabel 3.3 Maximaal toegestane fosfaatgiften in $\mathrm{kg} \mathrm{P}_{2} \mathrm{O}_{5}$ op bouwland in 2015-2017 (RVO.nl, 2016).

\begin{tabular}{|c|c|c|}
\hline Fosfaattoestand bodem & $\begin{array}{c}\text { Bouwland } \\
\text { (kg } \mathrm{P}_{2} \mathrm{O}_{5} / \mathrm{ha} \text { ) }\end{array}$ & 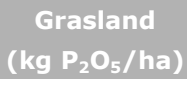 \\
\hline Laag & 75 & 100 \\
\hline Hoog & 50 & 80 \\
\hline
\end{tabular}




\subsubsection{Concurrentie dierlijke mest}

In 2015 produceerde de Nederlandse landbouw sector 75 kton P waarmee de plaatsingsruimte van 60 kton met 25\% (15 kton) werd overschreden. Door het overschot aan nutriënten is het gebruik van minerale fosfaatmeststof sterk teruggedrongen. In 2014 werd nog 4 kton $P$ in de vorm van fosfaatkunstmest gebruikt (Figuur 3.1), vooral bij de aardappel, snijmaïs en vollegrondsgroenten. Binnen Nederland zijn er grote regionale verschillen in de mestdruk (Figuur 3.2). Noord-Brabant, Gelderland en Overijssel kampen met een overschot aan dierlijke mest, terwijl er in Zeeland, Groningen en Flevoland mogelijkheden zijn om extra mest van buiten de provincie te plaatsen.

Door het overschot aan fosfor op de Nederlandse markt is een situatie ontstaan waarbij akkerbouwers geld toe krijgen wanneer ze fosfaat-houdende dierlijke mest 'aankopen'. Rundermest heeft een gunstige samenstelling en kan zodoende tegen betaling worden afgezet in de akkerbouw. Varkensmest wordt veelal in mestverwerkingsinstallaties verwerkt waarna de fosfaathoudende mestverwerkingsproducten na hygiënisatie worden geëxporteerd naar Duitsland, Frankrijk en OostEuropese landen. Kippenmest wordt grotendeels thermisch verwerkt.

De totale hoeveelheid fosfaat in de vorm van zuiveringsslib (11 kton $\mathrm{P}$ ) is voldoende om ruim $18 \%$ van de plaatsingsruimte op Nederlandse landbouwgronden (60 kton P) te vervullen. Bij grootschalige afzet van slib of slibproducten naar de landbouw is het $\mathrm{P}$-aanbod vanuit de afvalwatersector daarmee aanzienlijk t.o.v. de plaatsingsruimte waardoor concurrentie met de afzet van dierlijke mest ontstaat.

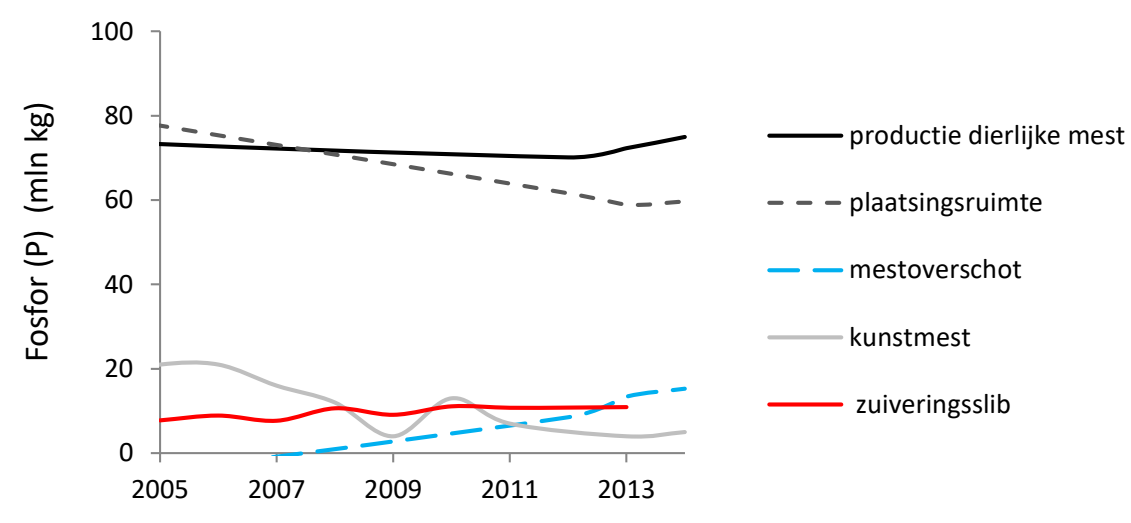

Figuur 3.1 Jaarlijkse P-productie in de vorm van dierlijke mest, P-plaatsingsruimte in de Nederlandse landbouw, het P-overschot in de vorm van dierlijke mest en de P-productie in de vorm van zuiveringsslib (Data: CBS, 2014). 


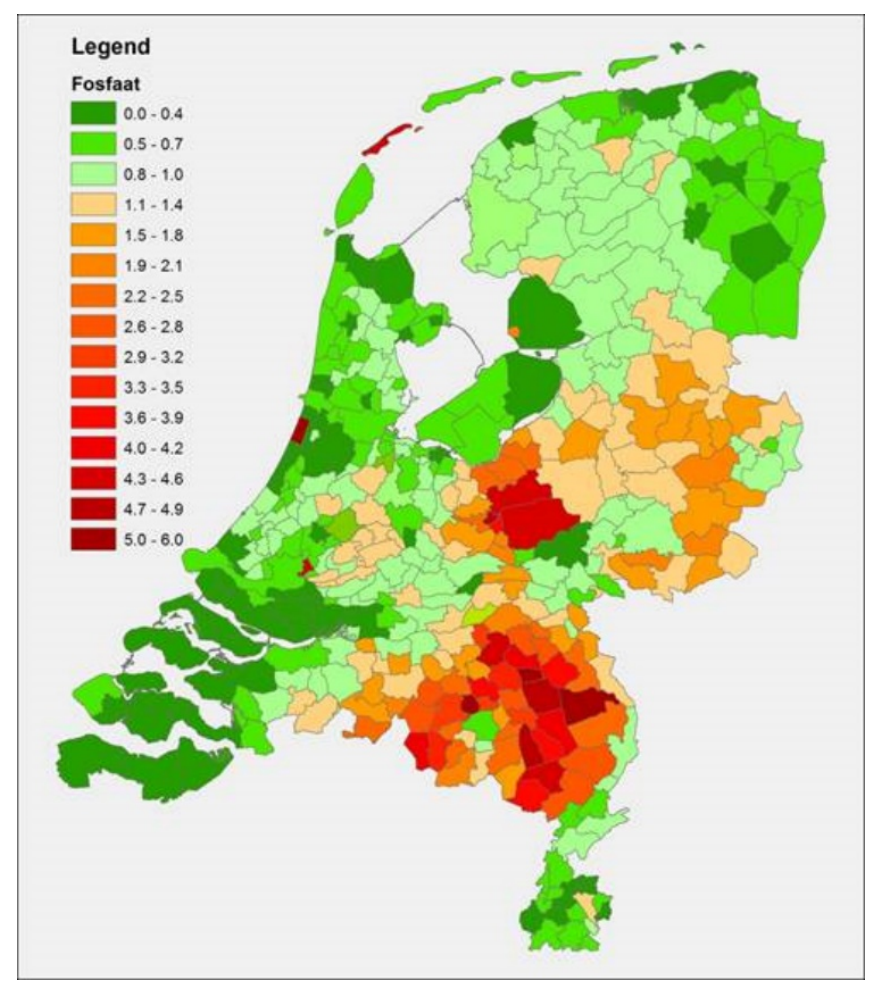

Figuur 3.2 De druk op de mestmarkt per gemeente in 2012. De P-productie in de agrarische sector gedeeld door de P-gebruiksruimte (De Koeijer et al. 2017).

\subsubsection{Organische bodemverbeteraars}

Bodemverbeteraars, veelal bestaande uit GFT- of groencompost, zijn producten die primair zorgen voor de aanvoer van organische stof en in mindere mate voor de aanvoer van nutriënten. In de akkerbouw en in de bollenteelt is er behoefte aan bodemverbeteraars die bijdragen aan het behoud van de organische stof in de bodem. Een bodemverbeteraar moet daarom een hoog gehalte aan effectieve organische stof hebben, gedefinieerd als organische stof die na een jaar nog in de bodem aanwezig is en dus bijdraagt aan de organische stofvoorraad in de bodem.

Om voldoende organische stof aan te kunnen voeren binnen de fosfaatgebruiksnormen, moet het gehalte aan $\mathrm{P}$ in het product voldoende laag zijn. Compost profiteert hierbij van een fosfaatvrije voet, waardoor het fosfaatgehalte voor $50 \%$ (tot $3,5 \mathrm{~g} \mathrm{P}_{2} \mathrm{O}_{5} / \mathrm{kg}$ ) is vrijgesteld voor de fosfaatgebruiksnorm. Compost geniet deze uitzonderingspositie, omdat compost voor circa $60 \%$ uit minerale delen bestaat afkomstig van grond. Grond bevat fosfaat en het recirculeren van grond zorgt netto gezien niet voor een toename in het fosfaatgehalte van grond. Zodoende is beredeneerd door het ministerie van VROM met belanghebbend bedrijfsleven (composteerders) dat het fosfaatgehalte in compost gecorrigeerd moet worden voor de 'basisvracht' van fosfaat die met grond wordt aangevoerd (Ehlert, 2005). In Nederland wordt jaarlijks circa 2 miljoen ton compost geproduceerd (GFT-compost en groencompost). De landbouw (akkerbouw, vollegrond) is de grootste afnemer van compost en verantwoordelijk voor $60 \%$ van de afname van het totale volume aan compost (BVOR, 2015). Compost wordt voor een groot deel afgezet in akkerbouwgebieden in Noord-Brabant, Gelderland en Zuid-Holland. Kwalitatief goede bodemverbeteraars kunnen met een positieve waarde van circa $€ 9$ tot $€ 18$ per ton worden afgezet (Wit, 2013).

\subsubsection{Export van gecomposteerd slib}

Evenals voor dierlijke mest kan export van verwerkt zuiveringsslib naar landen met een behoefte aan nutriënten en een acceptatie van zuiveringsslib als meststof een manier zijn om slib terug te brengen naar de landbouw. Enkele jaren geleden werd de afzet van zuiveringsslib naar Duitsland nog als mogelijkheid beschouwd (IJzerman et al. 2014), maar met het komende verbod op het landbouwkundig gebruik van zuiveringsslib is het perspectief voor deze route komen te vervallen. Op dit moment wordt 
export naar Frankrijk als meest perspectiefvolle route gezien vanwege de vraag naar fosfaatmeststoffen, de relatief soepele normen voor zware metalen en de acceptatie van het gebruik van slib in de landbouw (voornamelijk wijnteelt). Uiteraard dient het product wel aan de (strenge) criteria voor microbiologische kwaliteit en traceerbaarheid te voldoen conform de eisen van het ontvangende land. Echter, deze afzetroute wordt belemmerd door de afvalstatus van zuiveringsslib, waardoor de export zowel juridisch als administratief zeer complex is en alleen interessant is wanneer grote volumes afgezet kunnen worden. GMB-BioEnergie heeft deze afzetroute uitgebreid verkend en is voornemens om zijn gecomposteerde slib in de toekomst als meststof af te zetten in Frankrijk.

\subsubsection{Herwonnen fosfaatmeststoffen}

\section{Minerale fosfaat meststof}

Herwonnen fosfaten zijn sinds 2014 als aparte categorie opgenomen in het Uitvoeringsbesluit Meststoffenwet waarmee de afvalstatus is opgeheven en herwonnen fosfaten als product in Nederland vrij als meststof kan worden verhandeld. Echter, in de Nederlandse landbouw is de vraag naar minerale fosfaatmeststoffen zeer beperkt als gevolg van het fosfaataanbod van dierlijke meststoffen. In een recente marktverkenning (Evers et al. 2016) is geschat dat de marktomvang voor gekorreld struviet uit afvalwater maximaal 6400 tot 8300 ton struviet per jaar bedraagt, wat overeenkomt met circa 0.7 kton P. De potentiële marktomvang is daarmee zeer klein ten opzichte van de totale hoeveelheid $P$ in zuiveringsslib (11 kton). Op dit moment is de productie aan herwonnen fosfaatmeststoffen uit afvalwater dusdanig laag dat export niet interessant is. Indien het aanbod in de toekomst toeneemt, kan export een haalbare afzetroute vormen. De mogelijkheden tot export kunnen vereenvoudigen wanneer herwonnen fosfaten uit communaal afvalwater worden opgenomen in de toekomstige EU-Meststoffenverordening (par. 2.4).

\section{Grondstof}

Herwonnen fosfaten kunnen door ICL Fertilizers (Amsterdam) gebruikt worden als alternatief voor ruwe fosfaaterts in de productie van hoogwaardige fosfaatmeststof. Opwerking via deze route heeft als voordeel dat het eindproduct een constante en gegarandeerde kwaliteit heeft en dat het product via bestaande afzetkanalen afgezet en geëxporteerd kan worden. Het productieproces van ICL Fertilizers is afgestemd op de verwerking van ruwe fosfaatgrondstoffen (calciumfosfaten) en daardoor niet geschikt voor de opwerking van ijzerhoudende fosfaatgrondstoffen.

\subsection{Positionering van slib als meststof of bodemverbeteraar}

Tabel 3.4 toont de samenstelling van zuiveringsslib, gecomposteerd slib (biogranulaat), dierlijke mest en compost. De samenstelling van slib en slibproducten bepaalt of het product gepositioneerd dient te worden als meststof of bodemverbeteraar. Het fosfaatgehalte van zuiveringsslib is, op basis van droge stof, circa 4 maal hoger dan in runderdrijfmest en 1,5 maal hoger dan in varkensmest. Het stikstofgehalte in zuiveringsslib is lager dan in dierlijke mest. Bij de huidige samenstelling moet zuiveringsslib gepositioneerd worden als een organische fosfaatmeststof.

In landbouwkundig opzicht zijn de verhoudingen tussen de waarde-gevende bestanddelen van belang. Een product met een hoog gehalte aan organische stof en stikstof per kg fosfaat is goed te plaatsen in de akkerbouw. Dit komt omdat de aanvoer van organische stof en stikstof met dierlijke mest (of slib) onder de huidige wetgeving beperkt wordt door de fosfaatgebruiksnormen. Compost kenmerkt zich door een hoge organische stofaanvoer per kg fosfaat ten opzichte van mest en slib (Tabel 3.4). Rundermest onderscheidt zich positief van varkensmest door de hogere aanvoer van organische stof en stikstof per kilogram fosfaat. Bij bemesting met zuiveringsslib is de aanvoer van organische stof en stikstof lager dan bij bemesting met dierlijke mest. Dit maakt dat het gebruik van dierlijke mest landbouwkundig gezien aantrekkelijker is dan zuiveringsslib. Dit geldt echter specifiek voor de Nederlandse situatie waarin de fosfaatdosering door wetgeving beperkt wordt. In andere EU-lidstaten waar de fosfaatbemesting niet wordt beperkt, wordt het hoge fosfaatgehalte van zuiveringsslib als gunstig ervaren. 
Tabel 3.4 Landbouwkundige samenstelling van zuiveringsslib, gecomposteerd slib (biogranulaat), GFT- en groencompost en dierlijke mest.

\begin{tabular}{|c|c|c|c|c|c|c|c|}
\hline Slib/Meststof & $\begin{array}{l}\text { D.S. } \\
(\%)\end{array}$ & $\begin{array}{c}0.5 . \\
\text { (\% d.s) }\end{array}$ & P & $\begin{array}{l}\mathrm{P}_{2} \mathrm{O}_{5} \\
(\mathrm{~g} / \mathrm{kg} \text { d.s. })\end{array}$ & N-tot & $\begin{array}{c}\text { OS-aanvoer } \\
\left(\mathrm{kg} \mathrm{OS} / \mathrm{kg} \mathrm{P}_{2} \mathrm{O}_{5}\right)\end{array}$ & $\begin{array}{c}\mathrm{N} \text {-aanvoer } \\
\left(\mathbf{k g ~ N} / \mathbf{k g ~} \mathrm{P}_{2} \mathrm{O}_{5}\right)\end{array}$ \\
\hline Slib $^{1}$ & 24 & 68 & 34 & 78 & 56 & 8.7 & 0.7 \\
\hline Groen compost $^{3}$ & 63 & 28 & 2.0 & $4.6(2.3)$ & 8 & 116 & 3.6 \\
\hline GFT compost ${ }^{3}$ & 67 & 34 & 2.9 & $6.6(3.3)$ & 12 & 102 & 3.6 \\
\hline Rundveedrijfmest $^{4}$ & 7 & 77 & 7.6 & 17 & 50 & 44 & 2.9 \\
\hline \multicolumn{8}{|c|}{ Hypothetische slib producten 5} \\
\hline Slibkoek - 50\% P & 24 & 68 & 17 & 39 & 56 & 18 & 1.4 \\
\hline Slibkoek - 25\% P & 24 & 68 & 8.5 & 20 & 56 & 35 & 2.9 \\
\hline \multicolumn{8}{|c|}{2 Gecomposteerd zuiveringsslib, locatie Zutphen, GMB BioEnergie, 2014.} \\
\hline \multicolumn{8}{|c|}{$\begin{array}{l}3 \text { Gemiddelde samenstelling in } 2014 \text { (BVOR, 2015). Tussen haakjes het forfaitaire } \mathrm{P}_{2} \mathrm{O}_{5} \text { gehalte. De OS-aanvoer en N-aanvoer zijn berekend } \\
\text { o.b.v. het forfaitaire } \mathrm{P}_{2} \mathrm{O}_{5} \text { gehalte. }\end{array}$} \\
\hline \multicolumn{8}{|c|}{4 Mediane samenstelling mest (Romkens en Rietra, 2012). } \\
\hline \multicolumn{8}{|c|}{5 Slib cq. biogranulaat met 50 en $25 \%$ van het initiële fosfaatgehalte. } \\
\hline
\end{tabular}

Door het fosfaatgehalte van slib te verlagen, kunnen de afzetmogelijkheden voor slib worden verruimd. Om te kunnen concurreren met de afzet van dierlijke mest is het gunstig om het fosfaatgehalte dusdanig te verlagen dat de organische stofaanvoer hoger is dan bij gebruik van dierlijke mest. In Tabel 3.4 is de samenstelling berekend van slibproducten met een verlaagd fosfaatgehalte.

- Wanneer het fosfaatgehalte van zuiveringsslib met circa 50\% wordt verlaagd, komt de samenstelling $(\mathrm{P}, \mathrm{N}, \mathrm{O} . \mathrm{S}$.$) van zuiveringsslib overeen met die van varkensmest.$

- Wanneer het fosfaatgehalte van zuiveringsslib met 75 à $80 \%$ wordt verlaagd, komt de samenstelling $(\mathrm{P}, \mathrm{N}, \mathrm{O} . \mathrm{S}$.) overeen met rundermest.

- Wanneer het fosfaatgehalte met meer dan $85 \%$ wordt verlaagd, komt de samenstelling overeen met compost.

Het verwijderen van 50 tot 75\% van het fosfaat uit zuiveringsslib is technisch haalbaar (Hoofdstuk 4). Echter, het verwijderen van meer dan $85 \%$ van het fosfaat om biogranulaat af te kunnen zetten als bodemverbeteraar lijkt technisch niet haalbaar. Daarbij is het zeer onwaarschijnlijk dat fosfaatverarmde biogranulaat in aanmerking zal komen voor een fosfaatvrije voet waardoor het product niet kan concurreren met de afzet van compost. Afzet van fosfaat-verarmd biogranulaat als bodemverbeteraar biedt daardoor geen perspectief. Biogranulaat leent zich vanwege het hoge drogestofgehalte en vergaande mate van hygiënisatie wel voor export naar landen met een vraag naar organische fosfaatmeststoffen. In landen zoals Frankrijk, waar in tegenstelling tot Nederland geen beperking is op de dosering van fosfaat op landbouwgronden, zijn organische meststoffen met een hoog fosfaatgehalte juist in trek. Export van slib behoort tot de mogelijkheden, maar gaat door de afvalstatus van het product gepaard met zware administratieve lasten voor zowel exporterende als importerende landen, waardoor deze vorm van slibafzet complex is.

In bovenstaande discussie worden de afzetmogelijkheden van slib mede beoordeeld op basis van de organische stofaanvoer. Dit kan de indruk wekken dat vergisting en compostering een negatief effect hebben op de landbouwkundige waarde van slib als meststof door afbraak van organische stof. Dit is echter niet het geval, omdat de effectieve organische stof behouden blijft. 


\subsubsection{Economische waarde van slib bij afzet in de landbouw}

Door de grote druk op de mestmarkt is er een tekort ontstaan voor plaatsingsruimte voor organische, fosfaatrijke meststoffen. Dierlijke mest wordt daardoor met geld toe afgezet (Tabel 3.5). De afzetkosten voor varkensmest bedroegen in 2015 gemiddeld 17 euro per ton mest. Hiervan is ongeveer 4-10 euro/ton voor transportkosten en mestanalyses en 7-13 euro vergoeding voor de afnemende partij (akkerbouwer of mestverwerker) (De Koeijer et al. 2017). De afzetkosten voor rundermest bedragen ongeveer 11 euro per ton en zijn lager dan de afzetkosten voor varkensmest vanwege het lagere fosfaatgehalte van rundermest.

Tabel 3.5 Afzetkosten incl. distributiekosten voor dierlijke mest 2015.

\begin{tabular}{|c|c|c|c|c|}
\hline & $\begin{array}{c}\text { Droge stof } \\
(\%)\end{array}$ & $\begin{array}{c}\mathrm{P}_{2} \mathrm{O}_{5} \\
(\mathrm{~g} / \mathrm{kg} \mathrm{d.s.})\end{array}$ & $\begin{array}{c}\mathrm{P}_{2} \mathrm{O}_{5} \\
(\mathrm{~g} / \mathrm{kg} \text { product) }\end{array}$ & $\begin{array}{l}\text { Afzetkosten }{ }^{1} \\
\text { C/ton product }\end{array}$ \\
\hline Varkensmest & 8 & 50 & 4 & $€ 17,-$ \\
\hline
\end{tabular}

Zuiveringsslib heeft landbouwkundig gezien geen voordelen boven dierlijke mest. Akkerbouwers zullen daarom de voorkeur hebben voor dierlijke mest (beter imago, bekendheid met samenstelling en werking etc.) waardoor waterschappen extra geld moeten toeleggen om zuiveringsslib in de landbouw af te kunnen zetten. Daarom wordt aangenomen dat de afzetkosten voor slib $25 \%$ hoger zijn dan de afzetkosten voor dierlijke mest (bij een gelijke samenstelling). Dit percentage is wellicht te laag en zal sterk samenhangen met het imago van zuiveringsslib en van de bereidheid van agrariërs en retailerorganisaties om zuiveringsslib als meststof te gebruiken. Verder is aangenomen dat het slib binnen een straal van $100 \mathrm{~km}$ kan worden afgezet zodat de transportkosten gelijk zijn aan de transportkosten voor dierlijke mest (Tabel 3.5). Daarnaast is aangenomen dat het slib wordt afgezet in de vorm van een verpompbaar product met circa 8-10\% droge stof zodat het product op dezelfde wijze op het land gebracht kan worden als dierlijke mest. Dit kan tevens een besparing opleveren op de kosten voor ontwatering, mits het product in de nabije regio kan worden afgezet.

Op basis van bovenstaande aannames zijn de volgende afzetkosten voor slib en fosfaat-verarmd slib geschat:

- Zuiveringsslib bevat circa $60 \%$ meer fosfaat dan varkensmest. Om te kunnen concurreren met de afzet van varkensmest zullen de afzetkosten evenredig met het fosfaatgehalte toenemen én wordt aangenomen dat $25 \%$ extra betaald wordt vanwege het imago van slib. De afzetkosten worden daarom geschat op $€ 33$ per ton slurry (8\% d.s.) incl. transportkosten of $€ 413$ per ton droge stof.

- Na 50\% fosfaatverwijdering komt de samenstelling van zuiveringsslib overeen met die van varkensmest. De afzetkosten (bij $8 \%$ droge stof) worden geschat op $125 \%$ van de afzetkosten voor varkensmest. Dit komt overeen met $€ 21$ per ton slurry incl. transportkosten of $€ 265$ per ton droge stof.

- $\mathrm{Na} 75 \%$ fosfaatverwijdering komt de samenstelling van zuiveringsslib overeen met die van rundermest. De afzetkosten worden geschat op $125 \%$ van de afzetkosten voor rundermest. Dit komt overeen met $€ 14$ per ton slib incl. transportkosten of $€ 172$ per ton droge stof.

Bij het vergelijken van de geschatte afzetkosten naar de landbouw met het huidige poorttarief voor de thermische verwerking van slibkoek moet rekening gehouden worden met de verschillen in drogestofgehalte. Bij de afzet van slib naar de landbouw is uitgegaan van afzet bij circa $8-10 \%$ droge stof (verpompbaar), terwijl slib voor afzet naar een slib-eindverwerker wordt ontwaterd tot circa $25 \%$ droge stof. De inschatting van het economisch perspectief voor afzet van slib naar de landbouw is onzeker, omdat zowel de slibmarkt als mestmarkt op dit moment volop in beweging is. De afzetkosten voor slibeindverwerking zijn op dit moment zeer laag, terwijl de afzetkosten voor dierlijke mest de laatste jaren juist zijn gestegen. Het is niet mogelijk om een toekomstvoorspelling te doen en het perspectief is nu op basis van de huidige afzetprijzen beoordeeld. 


\subsection{Conclusies}

- De totale slibproductie bevat voldoende fosfaat om $18 \%$ van de totale fosfaatgebruiksruimte in Nederland op te vullen.

- Bij de afzet van zuiveringsslib naar de landbouw moet slib concurreren met de afzet van dierlijke mest. Vanwege het fosfaatoverschot in de agrarische sector wordt dierlijke mest met geld toe afgezet. Het hoge fosfaatgehalte van slib t.o.v. dierlijke mest, en de daardoor lage aanvoer van stikstof en organische stof per eenheid fosfaat, is hierbij nadelig.

- Door het fosfaatgehalte van zuiveringsslib te verlagen, neemt de mate van verdringing van dierlijke mest af. Wanneer het fosfaatgehalte met $75 \%$ wordt verlaagd, ontstaat een meststof die qua samenstelling overeenkomt met runderdrijfmest wat met bijbetaling aan de afnemer goed geplaatst kan worden in de landbouw.

- De afzet van (gecomposteerd) slib als bodemverbeteraar (i.e. vervanger van compost) vereist dat het fosfaatgehalte met circa $85 \%$ wordt verlaagd en dat het product - evenals compost - in aanmerking komt voor een fosfaatvrije voet. Deze route wordt niet haalbaar geacht.

- Het economisch voordeel van de afzet van fosfaat-verarmd slib naar de landbouw hangt sterk samen met de kosten voor fosfaatverwijdering en de mogelijke besparing op slibontwatering. 


\section{$4 \quad$ Verwijdering en terugwinning van fosfaat}

\subsection{Inleiding}

Zuiveringsslib kenmerkt zich door een hoog fosfaatgehalte waardoor slib bij afzet naar de landbouw moet concurreren met de afzet van fosfaat uit dierlijke mest. De afzetmogelijkheden voor slib kunnen verruimd worden door slib te scheiden in een minerale fosfaat meststof en een fosfaat-verarmde organische bodemverbeteraar. Hiervoor is het wenselijk om het fosfaatgehalte met circa $75 \%$ te verlagen (Hoofdstuk 3).

Er zijn diverse technologieën beschikbaar waarmee fosfaat kan worden teruggewonnen uit ingedikt slib (o.a. Airprex technologie) of uit het water dat vrijkomt bij de ontwatering van slib (rejectiewater, o.a. Pearl, Phospaq). Met deze terugwinningstechnieken, die uitsluitend kunnen worden toegepast op RWZI's met een biologische defosfatering, kan circa 10 tot $45 \%$ van de fosfaatvracht in het influent van de RWZI worden teruggewonnen (Lodder et al. 2011). Omdat deze technieken alleen het orthofosfaat uit de waterfase terugwinnen, kunnen deze niet ingezet worden om het fosfaatgehalte van het ontwaterde slib vergaand te verlagen. Hiervoor is een aanvullende stap nodig waarbij fosfaat actief uit het slib geëxtraheerd wordt.

Voor de vergaande verwijdering en terugwinning van fosfaat uit zuiveringsslib of vergelijkbare matrices (dierlijke mest) wordt veelal gebruikgemaakt van een twee-staps aanpak waarbij fosfaat door aanzuren in oplossing wordt gebracht en vervolgens na scheiding wordt teruggewonnen uit het rejectiewater door dosering van base (Figuur 4.1). Voor zuiveringsslib zijn onder andere het Gifhornen Stuttgart-proces ontwikkeld waarbij fosfaat door dosering van zwavelzuur in oplossing wordt gebracht. Om co-precipitatie van ijzer en zware metalen met struviet te voorkomen, worden deze metalen gebonden door dosering van natriumsulfide (Gifhorn proces) of citroenzuur (Stuttgart proces) (Montag et al. 2015). Als alternatief voor aanzuren met zwavelzuur kan de pH verlaagd worden door onder koolstofdioxide onder hoge druk (10 bar) in het slib te injecteren (Budenheim proces, Nättorp, 2013). Toepassingen van deze technologieën beperken zich vooralsnog tot pilotschaal of demonstratieschaal. Voor digestaat van dierlijke mest is een vergelijkbaar concept ontwikkeld waarbij fosfaat met zwavelzuur uit de dikke mestfractie wordt geëxtraheerd en vervolgens door toediening van kalkmelk wordt teruggewonnen in de vorm van calciumfosfaatslib (Schoumans et al. 2014). Deze technologie wordt in 2018 opgeschaald tot een grootschalige demonstratie-pilot als onderdeel van de Groene Minerale Centrale voor de verwerking van varkensmest. In dit hoofdstuk is getest of een vergelijkbare aanpak perspectief biedt voor toepassing op zuiveringsslib.

Een andere ontwikkeling is om de extractie van fosfaat te combineren met slibeindverwerking d.m.v. hydrothermale behandeling van zuiveringsslib. Bij hydrothermale behandeling wordt slib bij hoge temperatuur en onder hoge druk behandeld waarbij veranderingen optreden in de eigenschappen van de organische stof. Afhankelijk van de temperatuur en verblijftijd wordt gesproken van Torwash ( $\approx 170-190^{\circ} \mathrm{C}, 10-30$ minuten) of hydrothermale carbonisatie (HTC, $\approx 200-240^{\circ} \mathrm{C}$, uren). Torwash en HTC worden beide toegepast als techniek voor slibeindverwerking vanwege de gunstige effecten op slibontwatering. Het eindproduct na ontwatering, de hydrochar, heeft een hoogcalorische waarde die vergelijkbaar is met bruinkool en kan zodoende afgezet worden als brandstof (Berge et al. 2011). Bij hydrothermale behandeling van biomassa (i.e. lignine-houdend materiaal) wordt een zeer sterke verzuring waargenomen, waardoor fosfaat in oplossing gaat (Hoekman et al. 2013; Reza et al. 2013). Dergelijke effecten van hydrothermale behandeling op de zuurgraad zijn echter niet waargenomen in studies met zuiveringsslib of dierlijke mest (Escala et al. 2012). Wel is aangetoond dat hydrothermale behandeling resulteert in omzetting van organisch fosfaat naar anorganisch fosfaat (Heilmann et al. 2014) waardoor het aandeel oplosbaar of extraheerbaar ortho-fosfaat mogelijk toeneemt. In dit project wordt beoordeeld of Torwash en HTC een effect hebben op de oplosbaarheid van fosfaat. 
Bij de afzet van slib of herwonnen fosfaat naar de landbouw kunnen zware metalen een knelpunt vormen. Het aanzuren van slib kan leiden tot het in oplossing gaan van zware metalen (Marchioretto et al. 2005). Wanneer de extractie van fosfaat gecombineerd kan worden met het opschonen van slib, kan een win-winsituatie ontstaan. Echter, het oplossen van zware metalen tijdens de fosfaatextractie kan eveneens consequenties hebben voor de kwaliteit van het herwonnen fosfaat. Zodoende is beoordeeld hoe de zware metalen zich na de fosfaatextractie verdelen over de slibfractie en het herwonnen fosfaat.

Dit hoofdstuk heeft als doel om de haalbaarheid van vergaande fosfaatverwijdering en terugwinning door middel van zuur- en basedosering te beoordelen. Hiervoor zijn labtesten uitgevoerd met slib van negen RWZI's die sterk verschillen in samenstelling (ijzer- en aluminiumdosering) en slibbehandeling (vergist, niet-vergist, ontwaterd). De labtesten in deze studie beperken zich tot de eerste stap, waarin fosfaat door aanzuren wordt geëxtraheerd omdat deze stap bepalend is voor de mate waarin fosfaat verwijderd kan worden. De tweede stap, waarin fosfaat door basedosering wordt teruggewonnen, vormde geen onderdeel van de labtesten.

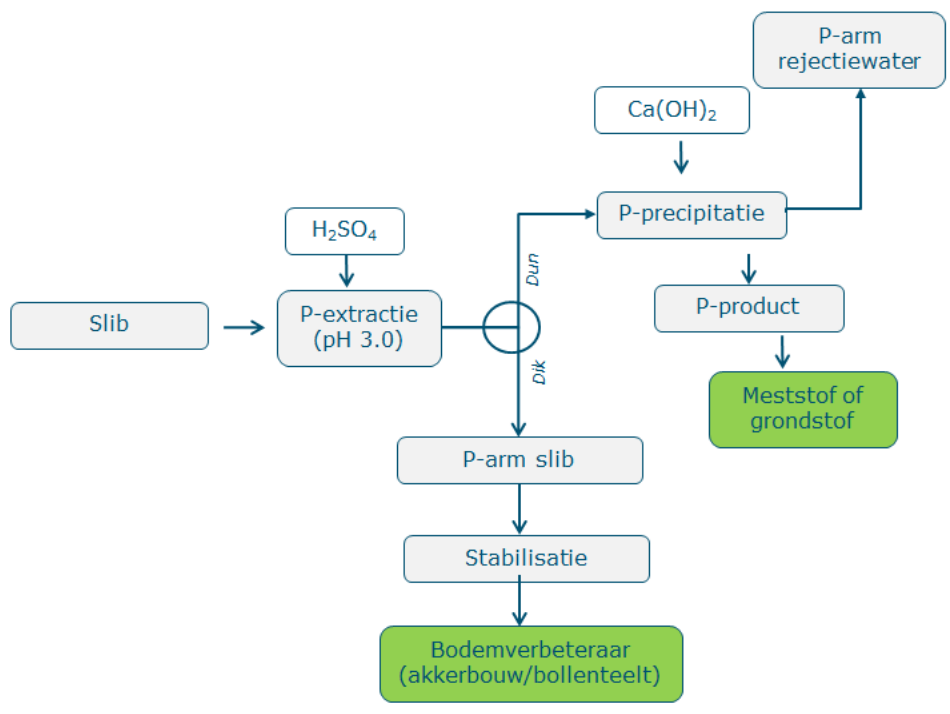

Figuur 4.3 Schematisch concept voor het scheiden van slib in een minerale P-meststof en een $P$-verarmde slibstroom door middel van zuur- en basedosering.

\subsection{Materiaal en methoden}

\subsubsection{Selectie van RWZI's en slibmonsters}

Er zijn negen RWZI's geselecteerd voor het nemen van slibmonsters (Tabel 4.1).

Op vijf locaties is slib bemonsterd in de vorm van ontwaterde slibkoek met circa $25 \%$ droge stof. Olburgen werd geselecteerd als RWZI met een volledige chemische defosfatering. RWZI Den Bosch, Nieuwgraaf en Etten zijn uitgerust met een biologische defosfatering en aanvullende ijzerdosering. Op de RWZI in Oijen worden, als aanvulling op de biologische defosfatering, aluminium en ijzer gedoseerd. RWZI Etten in Terborg ontvangt o.a. afvalwater van een papierfabriek en de RWZI Nieuwgraaf in Duiven ontvangt relatief veel industrieel afvalwater. Op drie locaties (Zutphen, AarleRixtel, Asten en Amsterdam) is slib bemonsterd in de vorm van ingedikt slib met circa 3,5\% droge stof. Dit betreft allemaal RWZI's met een goedwerkende BioP-installatie waar vrijwel geen aanvullende ijzerdosering wordt toegepast. Het slib van Zutphen is niet-vergist. Het slib van Aarle-Rixtel bestaat 
voor $80 \%$ uit niet-vergist slib van RWZI Aarle-Rixtel en voor $20 \%$ uit vergist slib van RWZI Asten. Het slib van RWZI Asten is bemonsterd na vergisting. Op RWZI Amsterdam is vergist slib bemonsterd voor- en na de struvietreactor (Airprex). Het slib bestaat in alle gevallen uit primair en secundair slib.

Tabel 4.6 Beschrijving van de bemonsterde locaties.

\begin{tabular}{|c|c|c|c|c|}
\hline Naam & Type materiaal & Defosfateringsmethode & Vergist & Opmerkingen \\
\hline Oijen & slibkoek & BioP + aanvullend chemisch $(\mathrm{Al}, \mathrm{Fe})$ & Nee & \\
\hline Olburgen & slibkoek & Chemisch (Fe) & $\mathrm{Ja}$ & \\
\hline Nieuwgraaf & slibkoek & BioP + aanvullend chemisch (Fe) & $\mathrm{Ja}$ & \\
\hline Aarle-Rixtel & Ingedikt slib & Volledig BioP & Nee & \\
\hline Asten & Ingedikt slib & Volledig BioP & Ja & \\
\hline Amsterdam-1 & Ingedikt slib & Volledig BioP & Ja & Voor struvietreactor \\
\hline Amsterdam-2 & Ingedikt slib & Volledig BioP & $\mathrm{Ja}$ & Na struvietreactor \\
\hline
\end{tabular}

\subsubsection{Karakterisering slib}

Op de slibmonsters zijn de volgende analyses uitgevoerd:

- Droge stof (bij $105^{\circ} \mathrm{C}$ )

- Organische stof (gloeiverlies bij $550^{\circ} \mathrm{C}$ )

- Totaal organisch koolstof (TC analyzer)

- Totaal $\mathrm{N}$ (destructie op vers slib)

- Totaal P, Ca, Mg, Fe, Al, S en zware metalen (Aqua Regia-destructie op gedroogd slib)

- Orthofosfaat in de waterfase (na centrifugeren, 40x verdunning en filtratie over 0,45 $\mu \mathrm{m}$ )

- Anorganisch en organisch P (extractie van fosfaat met zwavelzuur voor en na oxidatie van de organische stof bij $550^{\circ} \mathrm{C}$ )

- Polyfosfaat (hydrolyse van polyfosfaat door verhitting gevolgd door extractie met zwavelzuur en analyse van de orthofosfaat-concentratie)

In Bijlage 1 is een gedetailleerde beschrijving van de gebruikte analyses opgenomen.

\subsubsection{Extracties met zwavelzuur}

Het slib is gekoeld bewaard bij $4{ }^{\circ} \mathrm{C}$ tot de uitvoering van de labtesten. Omdat het extraheren en afscheiden van fosfaat uit slib alleen mogelijk is bij goed roerbare monsters, zijn de slibmonsters waar nodig met water verdund. De ontwaterde slibkoek is hiervoor met water verdund tot een roerbare slurry met drogestofgehalte van 10\%. Voor RWZI Zutphen is de extractie uitgevoerd op het ingedikte slib zoals aangeleverd (3,7 \% d.s.). Het ingedikte slib van Aarle-Rixtel, Asten en Waternet is verdund tot $2 \%$ droge stof. Het slib is onderworpen aan een zuurtitratie waarbij het zuurbufferend vermogen en concentraties van fosfaat, kationen en zware metalen zijn bepaald. De slurries $(500 \mathrm{~mL})$ zijn stapsgewijs getitreerd met een $1 \mathrm{M} \mathrm{H}_{2} \mathrm{SO}_{4}$-oplossing onder voortdurend roeren met een magneetroerder. Bij aanvang van de titratie en na aanzuren tot $\mathrm{pH} 6,5,4$ en 3 is een submonster genomen dat na $20 x$ verdunnen, centrifugeren en filtreren is geanalyseerd op orthoP, $\mathrm{P}$-totaal en kationen ( $\mathrm{Ca}, \mathrm{Mg}, \mathrm{Fe}, \mathrm{Al}, \mathrm{Cu}, \mathrm{Zn}$ ).

\subsubsection{Extracties met citroenzuur of natriumbicarbonaat}

Slib is verdund met water tot een roerbare slurry met $10 \%$ droge stof. Bij $100 \mathrm{~mL}$ slurry is vervolgens een hoeveelheid citroenzuur of natriumbicarbonaat gedoseerd overeenkomend met een dosering van 0,$45 ; 0,60 ; 0,75$ en $1,05 \mathrm{mmol}$ per $\mathrm{kg}$ droge stof. Na dosering is het slib in een afgesloten pot een uur geschud. Het supernatant is vervolgens $20 x$ verdund, gefiltreerd over 0,45 $\mu \mathrm{m}$ en geanalyseerd op orthoP, P-totaal en kationen ( $\mathrm{Ca}, \mathrm{Mg}, \mathrm{Fe}, \mathrm{Al}, \mathrm{Cu}, \mathrm{Zn})$. 


\subsubsection{Fosfaatterugwinning in combinatie met hydrothermale carbonisatie}

In een labopstelling is zuiveringsslib is onder hoge druk en bij hoge temperatuur verwerkt. De hydrothermale behandelingen zijn uitgevoerd door het Energie Centrum Nederland (ECN) te Petten. De testen zijn uitgevoerd op slibkoek van de RWZI's in Den Bosch, Oijen, Etten, Olburgen, Zutphen en Nieuwgraaf. De slibkoek is aangelengd met demiwater tot een slurry met $10 \%$ droge stof. Het slib van Zutphen is bemonsterd bij een drogestofgehalte van $3,7 \%$ en is derhalve niet verder aangelengd.

\section{Hydrothermale Carbonisatie}

Slib is gedurende 120 minuten verhit bij 200 graden ${ }^{\circ} \mathrm{C}$ en bij circa 20 bar. De test is uitgevoerd met autoclaven met een volume van $100 \mathrm{~mL}$. Per monster zijn drie autoclaven gebruikt zodat in totaal $300 \mathrm{~mL}$ slib behandeld is. Het opwarmen en afkoelen neemt enkele uren in beslag.

Torwash

Slib is gedurende 30 minuten verhit bij 180 graden ${ }^{\circ} \mathrm{C}$ in $100 \mathrm{~mL}$ autoclaven. Per locatie is twee maal $100 \mathrm{~mL}$ slib verhit. Het opwarmen en afkoelen neemt enkele uren in beslag.

$\mathrm{Na}$ hydrothermale behandeling is de verdeling van fosfaat over de vaste fase en vloeistof bepaald en zijn zuurtitraties uitgevoerd om te beoordelen of hydrothermale behandeling leidt tot een verandering in de mate van zuurbuffering en fosfaatoplosbaarheid. Het slib is met geconcentreerd zwavelzuur aangezuurd tot $\mathrm{pH} 4$ en pH 3 . Na aanzuren is het slib $20 x$ verdund en gecentrifugeerd ( $20 \mathrm{~min}$, $3500 \mathrm{rpm})$ waarna het supernatant is afgegoten en gefiltreerd $(0.45 \mu \mathrm{m})$. Het filtraat is geanalyseerd op orthoP, P-totaal, $\mathrm{Ca}, \mathrm{Mg}$, Fe, Al, Cu en $\mathrm{Zn}$.

\subsection{Resultaten}

\subsubsection{Samenstelling zuiveringsslib}

De samenstelling van de tien slibmonsters is gegeven Tabel 4.2. Het fosforgehalte varieert tussen de 22 en $37 \mathrm{~g} \mathrm{P}$ per kg drogestof, wat overeenkomt met 67 tot $113 \mathrm{~g} \mathrm{PO}_{4}$ per kg drogestof. Dit betekent dat zuiveringsslib voor 7 tot 11 massaprocent bestaat uit fosfaat. Het fosfaat gehalte is lager in ontwaterde slibkoek omdat circa 30\% van het fosfaat bij het ontwateren wordt verwijderd via het rejectiewater. Het organische stof gehalte varieert tussen de 62 en $77 \%$ en de $\mathrm{pH}$-waarde varieert tussen 5,8 en 7,7 .

De verschillen in ijzer- en aluminiumgehalten in slib tussen locaties zijn zeer groot. Op de RWZI in Olburgen en Den Bosch wordt ijzer gedoseerd, wat zich uit in hoge ijzergehalten in het slib $(45 \mathrm{~g} / \mathrm{kg}$ d.s). De hogere aluminiumgehalten in het slib van Oijen zijn gerelateerd aan de dosering van dit zout. De RWZI's van Zutphen en Aarle-Rixtel kenmerken zich juist door zeer lage ijzer- en aluminiumgehalten. Op deze RWZI's wordt geen aanvullende ijzerdosering toegepast. Echter, de relatief hoge ijzer- en aluminiumgehalten in slib van RWZI Asten en Amsterdam, waar eveneens geen aanvullende ijzerdosering wordt toegepast, geeft aan dat ook slib van RWZI's zonder aanvullende chemische defosfatering nog aanzienlijke hoeveelheden ijzer en aluminium kan bevatten. Het doseren van ijzer en aluminium leidt tot toename in de slibproductie. IJzer wordt gedoseerd in de vorm van ijzerzout $\left(\mathrm{FeCl}_{3}\right)$, maar wordt in de aanwezigheid van water omgezet tot ijzer-hydroxide (FeOOH. $1 / 2 \mathrm{H}_{2} \mathrm{O}, 105 \mathrm{gram} / \mathrm{mol}$ ). Bij een ijzergehalte van $45 \mathrm{~g} / \mathrm{kg}$ bestaat de slibmassa dus voor ruim 9 massaprocent uit Fe-hydroxide. De positieve effecten van Fe op de slibontwatering (Berkhof en Korving, 2016) moeten dan ook worden afgewogen tegen de productie van extra slibmassa door vorming van ijzer-hydroxide. 
Tabel 4.7 Samenstelling zuiveringssliba .

\begin{tabular}{|c|c|c|c|c|c|c|c|c|c|c|c|c|}
\hline RWZI & D.S. & 0.5 . & $\mathrm{pH}$ & $\mathbf{P}$ & $\mathrm{Fe}$ & Al & $\mathrm{Ca}$ & $\mathrm{Mg}$ & s & $\mathbf{K}$ & P-org & P-anorg \\
\hline & $(\%)$ & $(\%)$ & $(-)$ & \multicolumn{7}{|c|}{ (g/kg drogestof) } & $(\%)$ & $(\%)$ \\
\hline Den Bosch & 30 & 77 & 5,8 & 25 & 49 & 2.3 & 10 & 2.6 & 5.8 & 2.4 & $3 \%$ & $97 \%$ \\
\hline Etten & 23 & 73 & 7,8 & 30 & 22 & 5.6 & 22 & 6.9 & 13 & 3.6 & $1 \%$ & $99 \%$ \\
\hline Olburgen & 27 & 68 & 6,4 & 22 & 45 & 6.5 & 24 & 4.3 & 22 & 1.6 & $3 \%$ & $97 \%$ \\
\hline Aarle-Rixtel & 3.1 & 74 & 6,0 & 32 & 9 & 5 & 17 & 8.7 & 7.9 & 11.2 & n.b. & n.b. \\
\hline Asten & 4.3 & 62 & 7,7 & 37 & 13 & 18 & 23 & 7.4 & 11.1 & 13.9 & n.b. & n.b. \\
\hline Amsterdam-1 & 3.2 & 72 & 7,2 & 34 & 24 & 7 & 25 & 4.9 & 13.9 & 11.9 & n.b. & n.b. \\
\hline Amsterdam-2 & 3.6 & 72 & 7,4 & 35 & 22 & 6 & 22 & 18.4 & 12.3 & 12.3 & n.b. & n.b. \\
\hline
\end{tabular}

a D.s. = Drogestofgehalte (\% van versgewicht), O.S. = Organische stofgehalte bepaald via gloeiverlies o.b.v. droge stof, P-org = organisch-P als \% van P-totaal, P-anorg $=$ anorganisch $\mathrm{P}$ als $\%$ van $\mathrm{P}$-totaal, $\mathrm{n} . \mathrm{b} .=$ niet bepaald.

Bij RWZI's met een biologische defosfateringsstap wordt fosfaat door fosfaat-accumulerende bacteriën vastgelegd in de vorm van polyfosfaat. Polyfosfaat bestaat uit lange ketens van honderden tot enkele duizenden aaneengeschakelde orthoP moleculen (Kuroda et al. 2002). Het aandeel polyfosfaat in slib was in alle geanalyseerde slibmonsters echter onder de detectielimiet. Schijnbaar vindt er een snelle en volledige omzetting van polyfosfaat naar orthofosfaat plaats tijdens opslag van slib en/of tijdens analyse van orthofosfaat. Ook het aandeel organisch fosfaat is relatief laag. Na vergisting is fosfaat voor meer dan 94\% aanwezig in de vorm van anorganisch fosfaat.

Zuiveringsslib van RWZI's met een goedwerkende biologische defosfatering bevat meer magnesium dan slib van zuiveringen met een chemische defosfatering of een matig functionerende BioP-zuivering (Olburgen, Den Bosch, Oijen). Magnesium wordt, evenals kalium (K), opgenomen door fosfaataccumulerende bacteriën om de lading van polyfosfaat te compenseren. Polyfosfaat heeft een negatieve lading van 1 equivalent per mol P. Calcium kan, in tegenstelling tot magnesium en kalium, niet door fosfaat-accumulerende bacteriën als tegen-ion worden opgenomen (Barat et al. 2005). Het niet-vergiste slib van RWZI Aarle-Rixtel kenmerkt zich door zeer lage ijzer- en aluminiumgehalten. Daarentegen kenmerkt het slib van RWZI-Asten zich juist door duidelijk hogere ijzer- en aluminiumgehalten in het slib. In Amsterdam is zuiveringsslib bemonsterd voor- en na de struvietreactor. Na de struvietreactor heeft het slib een zeer hoog magnesiumgehalte door dosering van magnesium. Het fosfaatgehalte in het slib voor en na de struvietreactor is vergelijkbaar. Ten tijde van de monstername was de struvietreactor net weer in gebruik genomen, waardoor de struvietverwijdering nog niet voldoende op gang was.

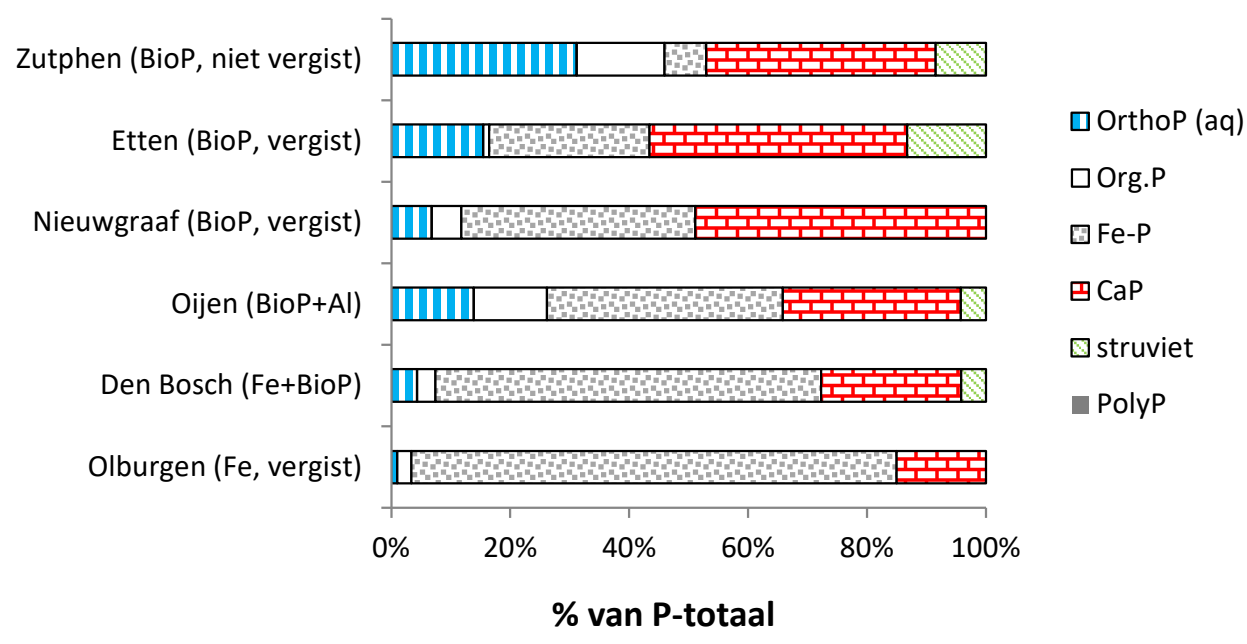

Figuur 4.4 Verdeling van fosfaat over orthoP, organisch $P$ en de verschillende minerale $P$ vormen in ingedikt slib (Zutphen) en slibkoek (Etten, Nieuwgraaf, Oijen, Den Bosch en Olburgen). OrthoP = orthofosfaat in de waterfase, OrgP = organisch fosfaat, Fe-P = fosfaat gebonden aan ijzer- en aluminium, CaP = calciumfosfaat. 
Op basis van de samenstelling is een schatting gemaakt (zie toelichting in Bijlage 1) van de verdeling van fosfaat over de verschillende organische en minerale vormen (Figuur 4.2). Fosfaat is grotendeels aanwezig in de vorm van anorganisch fosfaat (88-97\%). Afhankelijk van de samenstelling van het slib is het anorganisch fosfaat gebonden door adsorptie/precipitatie met ijzer, aluminium, calcium of magnesium. In ijzerrijk slib (Den Bosch en Olburgen) is 60 tot $80 \%$ van het fosfaat in slibkoek gebonden aan ijzer. In ijzerarm slib is fosfaat voor circa $40-50 \%$ aanwezig in de vorm van calciumfosfaat mineralen. Calciumfosfaat mineralen worden waarschijnlijk gevormd na hydrolyse van polyfosfaat onder anoxische omstandigheden. Het aandeel fosfaat wat wordt vastgelegd in de vorm van struviet wordt geschat op minder dan $15 \%$.

\subsubsection{Zuurbufferend vermogen van zuiveringsslib}

De mate van zuurbuffering van zuiveringsslib van de diverse locaties is weergegeven in Figuur 4.3 voor slibkoek en ingedikt slib. Voor ingedikt slib is het zuurbufferend vermogen hoger in vergist dan in niet-vergist slib door de vorming van bicarbonaat tijdens vergisten. In het ontwaterde slib is de zuurbuffering van vergist en niet-vergist slib vergelijkbaar, omdat het bicarbonaat door ontwateren grotendeels uit het slib wordt verwijderd. Ammonium draagt vrijwel niet bij aan het zuurbufferend vermogen omdat de $\mathrm{pH}$ van het slib onder de $\mathrm{pH}$ van het $\mathrm{NH}_{4}{ }^{+} / \mathrm{NH}_{3}$ evenwicht ligt ( $\mathrm{pH}$ 8.5). Wanneer het slib niet is vergist, heeft ontwateren vrijwel geen effect op het zuurbufferend vermogen.
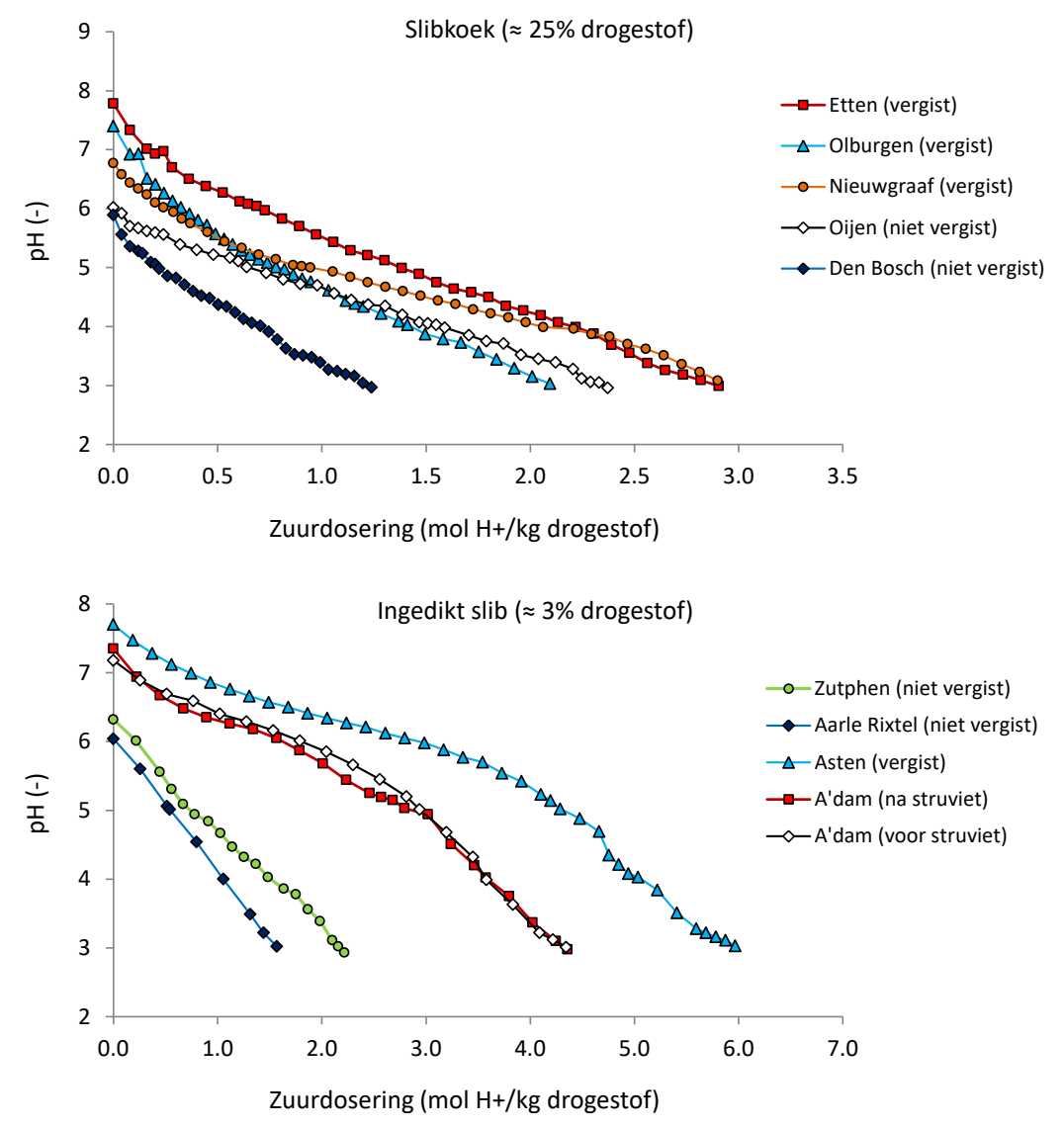

Figuur 4.5 De $\mathrm{pH}$ als functie van de zuurdosering bij het aanzuren van ontwaterde slibkoek ( $25 \%$ drogestof) of ingedikt slib ( $\approx 3 \%$ droge stof) met geconcentreerd zwavelzuur. 


\subsubsection{Extractie van fosfaat uit ontwaterde slibkoek}

In deze paragraaf worden de resultaten van de zuurextracties op ontwaterde slibkoek besproken. De resultaten van de zuur-extracties op ingedikt slib worden besproken in par. 4.3.4.

Figuur 4.4 toont het effect van de $\mathrm{pH}$ op het percentage fosfaat in de waterfase voor slibkoek ten opzichte van het totale fosfaatgehalte in slib van vijf RWZI's. Bij de ontwaterde slibkoek is het aandeel fosfaat in de waterfase vóór aanzuren relatief laag (1-16\%). Wanneer de pH daalt, neemt het aandeel fosfaat in de waterfase toe. Met name tussen pH 5 en pH 3 wordt een sterkte toename in de orthoPconcentratie geconstateerd. Het fosfaat in de waterfase bestaat volledig uit ortho-fosfaat. De concentratie aan organisch fosfaat was verwaarloosbaar. Na aanzuren tot pH 3 bevindt 20 tot $72 \%$ van het totale fosfaat zich in oplossing. De relatie tussen herkomst en samenstelling van het slib en de extraheerbaarheid van fosfaat worden hieronder per RWZI besproken.

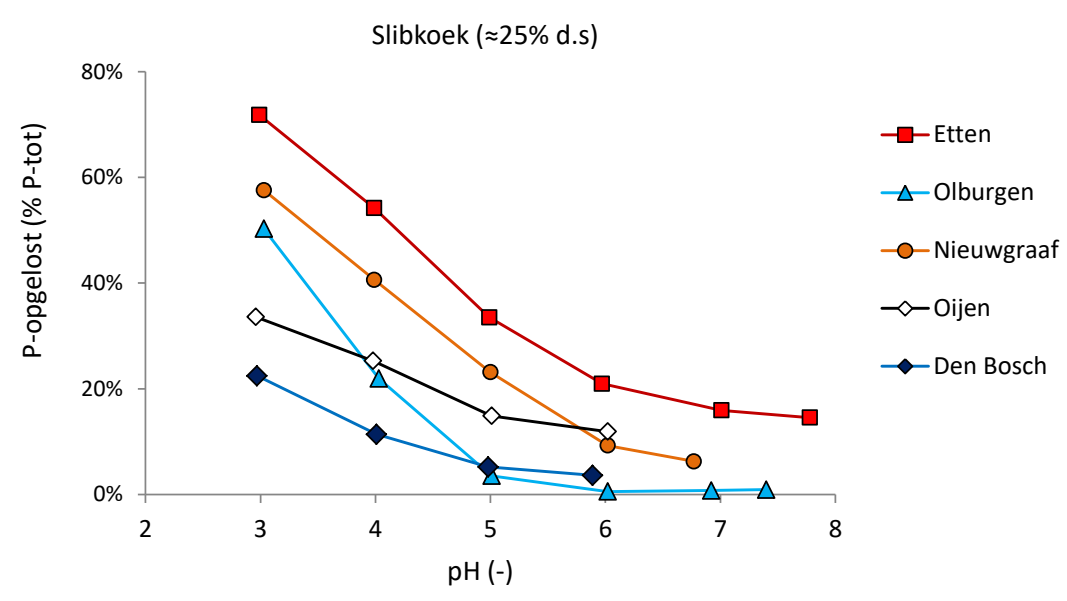

Figuur 4.6 Fosfaatconcentratie (orthoP) in de waterfase $(<0.45 \mu \mathrm{m}$ ) uitgedrukt als percentage van het totale fosfaatgehalte, na het aanzuren van ontwaterde slibkoek met zwavelzuur.

Figuur 4.5 toont de concentraties fosfaat en kationen ( $\mathrm{Fe}, \mathrm{Ca}, \mathrm{Mg}$ ) in de waterfase van het slib als percentage van de totale gehalten in slib. De concentraties in de waterfase zijn opgenomen in de figuur in Bijlage 2.

Voor RWZI Den Bosch (Fe-dosering, niet vergist) kan slechts $22 \%$ van het fosfaat opgelost worden door het slib aan te zuren tot $\mathrm{pH}$ 3. Deze zeer lage mate van fosfaatextractie is te wijten aan de binding van fosfaat aan ijzeroxiden. Circa $60 \%$ van het fosfaat is gebonden aan ijzeroxiden (Figuur 4.2). Het slib van Den Bosch is niet vergist waardoor Fe waarschijnlijk aanwezig is in de vorm van zeer slecht oplosbare Fe(III)-hydroxiden welke vrijwel niet oplossen bij pH 3.

Voor RWZI Oijen (Al-dosering, niet vergist) kan 34\% van het fosfaat worden geëxtraheerd bij pH 3. In Oijen wordt aluminium gedoseerd voor aanvullende fosfaatverwijdering en de binding van fosfaat aan aluminium verklaart de zeer lage oplosbaarheid van fosfaat. Aluminiumoxiden zijn zeer stabiel onder zure condities waardoor deze ook bij lage $\mathrm{pH}$ fosfaat kunnen binden. Slechts $6 \%$ van het totale aluminium wordt opgelost na aanzuren tot $\mathrm{pH}$ 3.0.

Voor RWZI Olburgen (Fe-dosering, vergist) kan 50\% van het fosfaat geëxtraheerd worden na aanzuren tot $\mathrm{pH}$ 3. Het gelijktijdig oplossen van fosfaat en ijzer in een 1:1 molverhouding wijst op het oplossen van $\mathrm{Fe}(\mathrm{II}) \mathrm{HPO}_{4}$ mineralen (Bijlage 2). Het slib van Olburgen kenmerkt zich, evenals het slib van Den Bosch, door een zeer hoog ijzergehalte. De hogere fosfaatoplosbaarheid is mogelijk te verklaren door het feit dat door vergisting het slecht oplosbare Fe(III) is gereduceerd tot het beter oplosbare Fe(II) waardoor de extractie op dit slib beter verloopt dan op het niet-vergiste slib van Den Bosch. 
Voor RWZI Etten en Nieuwgraaf (BioP, vergist) kan respectievelijk 58 en $72 \%$ van het totale fosfaat geëxtraheerd worden na aanzuren tot $\mathrm{pH}$ 3. Voor Etten wordt een hoger aandeel fosfaat geëxtraheerd dan voor Nieuwgraaf, wat overeenkomt met het lagere ijzergehalte in het slib van Etten. Het gelijktijdig in oplossing gaan van calcium en fosfaat in een mol-verhouding van circa $1: 1$ toont aan dat hier calciumfosfaat $\left(\mathrm{CaHPO}_{4}\right)$ mineralen worden opgelost (Bijlage 2). Calcium en magnesium zijn voor meer dan $90 \%$ in oplossing na aanzuren tot $\mathrm{pH} 3$, wat aangeeft dat calcium- en magnesiumfosfaatmineralen onder deze condities vrijwel volledig oplossen.
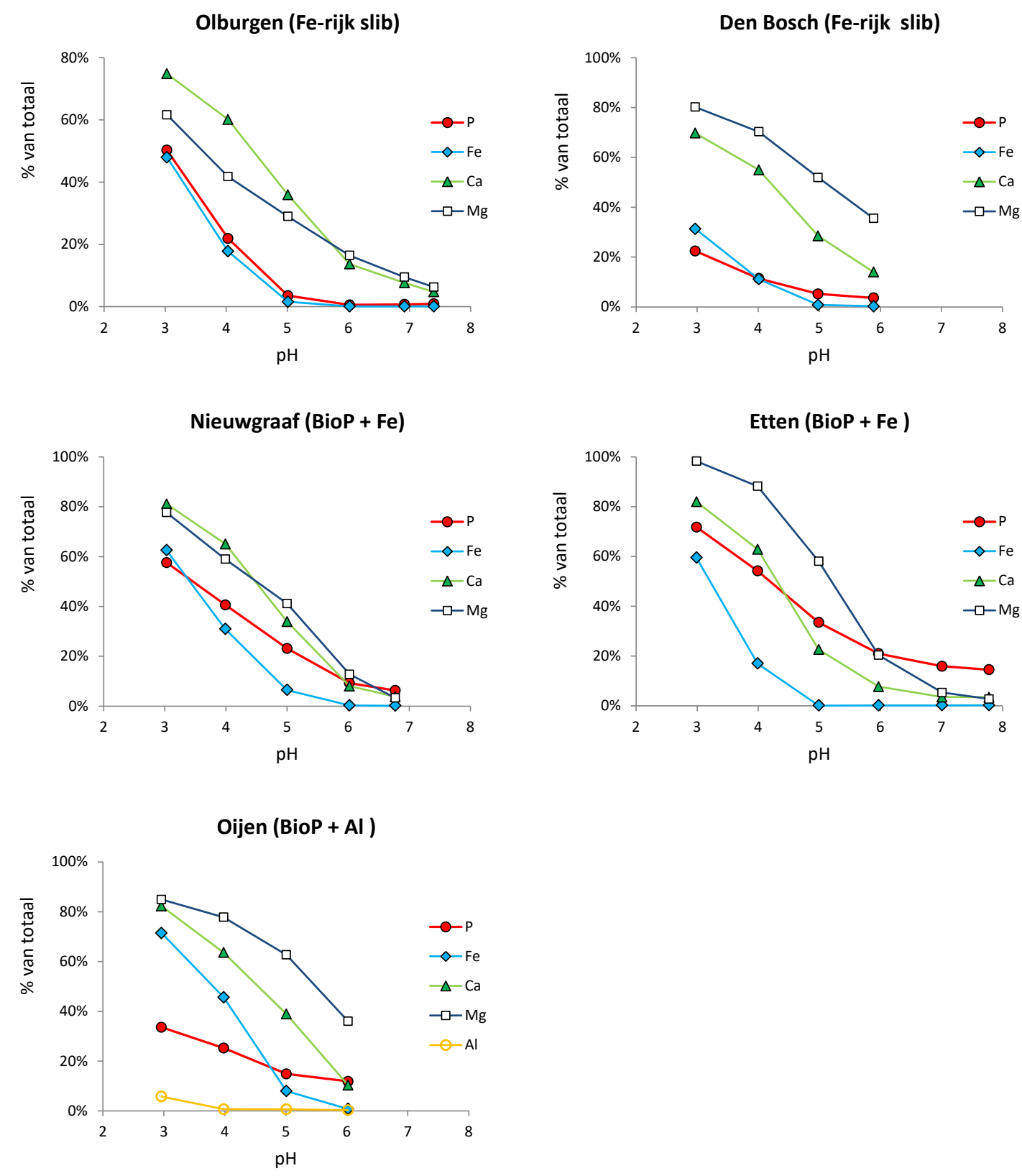

Figuur 4.7 Fosfaat (orthoP), ijzer, calcium en magnesium (mol/l) in de waterfase ( $<0.45 \mu \mathrm{m}$ ) van het slib als functie van de $\mathrm{pH}$ (na aanzuren met zwavelzuur) uitgedrukt als percentage van het totaalgehalte in het slib. 


\subsubsection{Extractie van fosfaat uit ingedikt slib}

Deze paragraaf beschrijft de resultaten van de zuurextracties op ingedikt slib met een drogestofgehalte van circa $3 \%$. Bij het ingedikte slib is, in tegenstelling tot slibkoek, een groot deel van het fosfaat reeds aanwezig in de waterfase voor het aanzuren. In het slib van RWZI Aarle-Rixtel is circa $65 \%$ van het fosfaat aanwezig in de waterfase zonder aanzuren. Voor locaties Zutphen, Asten en Amsterdam is dit circa $30 \%$. Echter, omdat ook het totale fosfaatgehalte hoger is in ingedikt slib dan in slibkoek, is een hogere terugwinningsrendement nodig om een vergelijkbare verlaging van het fosfaatgehalte in het slib te kunnen realiseren. $\mathrm{Na}$ het aanzuren van ingedikt slib tot $\mathrm{pH} 3$ bevindt 60 tot $82 \%$ van het totale fosfaat zich in de waterfase in de vorm van orthofosfaat.

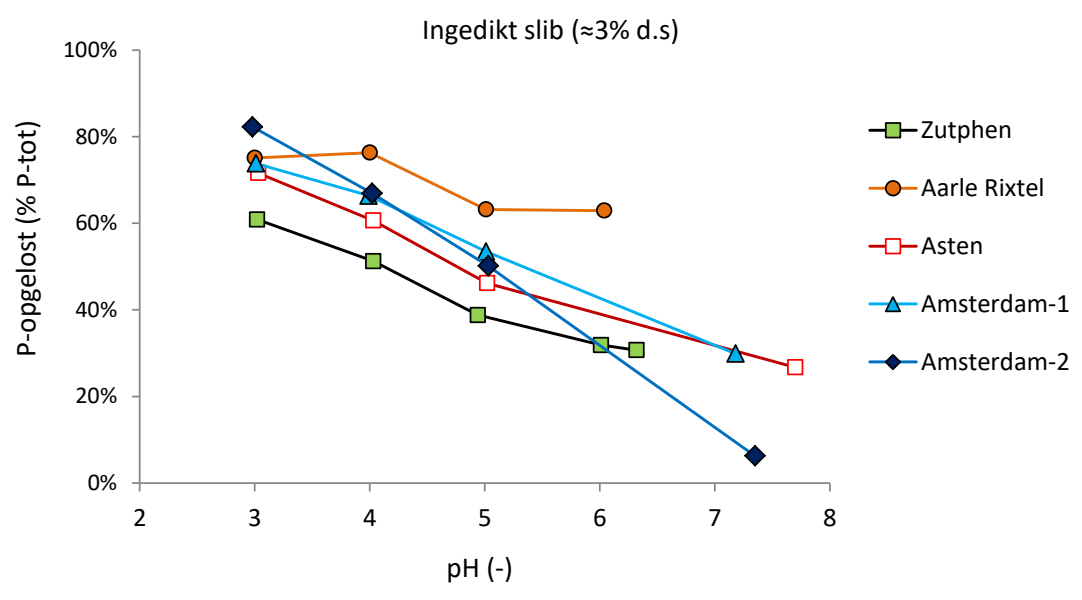

Figuur 4.8 Fosfaatconcentratie (orthoP) in de waterfase $(<0.45 \mu \mathrm{m}$ ) uitgedrukt als percentage van het totale fosfaatgehalte, na het aanzuren van ingedikt slib ( $\approx \%$ droge stof) met zwavelzuur.

Figuur 4.7 toont de concentraties fosfaat en kationen ( $\mathrm{Fe}, \mathrm{Ca}, \mathrm{Mg}$ ) in de waterfase van het slib na aanzuren met zwavelzuur. Voor slib van RWZI Zutphen wordt na aanzuren circa $60 \%$ van het fosfaat in oplossing gebracht als orthofosfaat. Dit relatief lage percentage is waarschijnlijk te wijten aan het hoge aandeel organisch fosfaat (18\%, Tabel 4.2$)$ in dit niet-vergiste slib. Calcium gaat voor $95 \%$ in oplossing, wat aangeeft dat het calciumgebonden fosfaat vrijwel volledig wordt geëxtraheerd.

Het slib van RWZI Aarle-Rixtel kenmerkt zich door een zeer hoge oplosbaarheid van fosfaat. Zonder aanzuren bevindt $65 \%$ van het fosfaat zich in oplossen en na aanzuren neemt dit percentage toe tot $75 \%$. Deze hoge percentages opgelost fosfaat kunnen verklaard worden door de zeer lage gehalten aan ijzer en calcium (Tabel 4.2) waardoor er weinig kationen beschikbaar zijn om fosfaat te binden.

Het slib van RWZI Asten heeft duidelijk een andere samenstelling dan het slib van Aarle-Rixtel, met hogere gehalten aan ijzer, aluminium en calcium waardoor meer fosfaat gebonden is. Het fosfaat laat zich evenwel goed oplossen na aanzuren met zwavelzuur (72\%). 

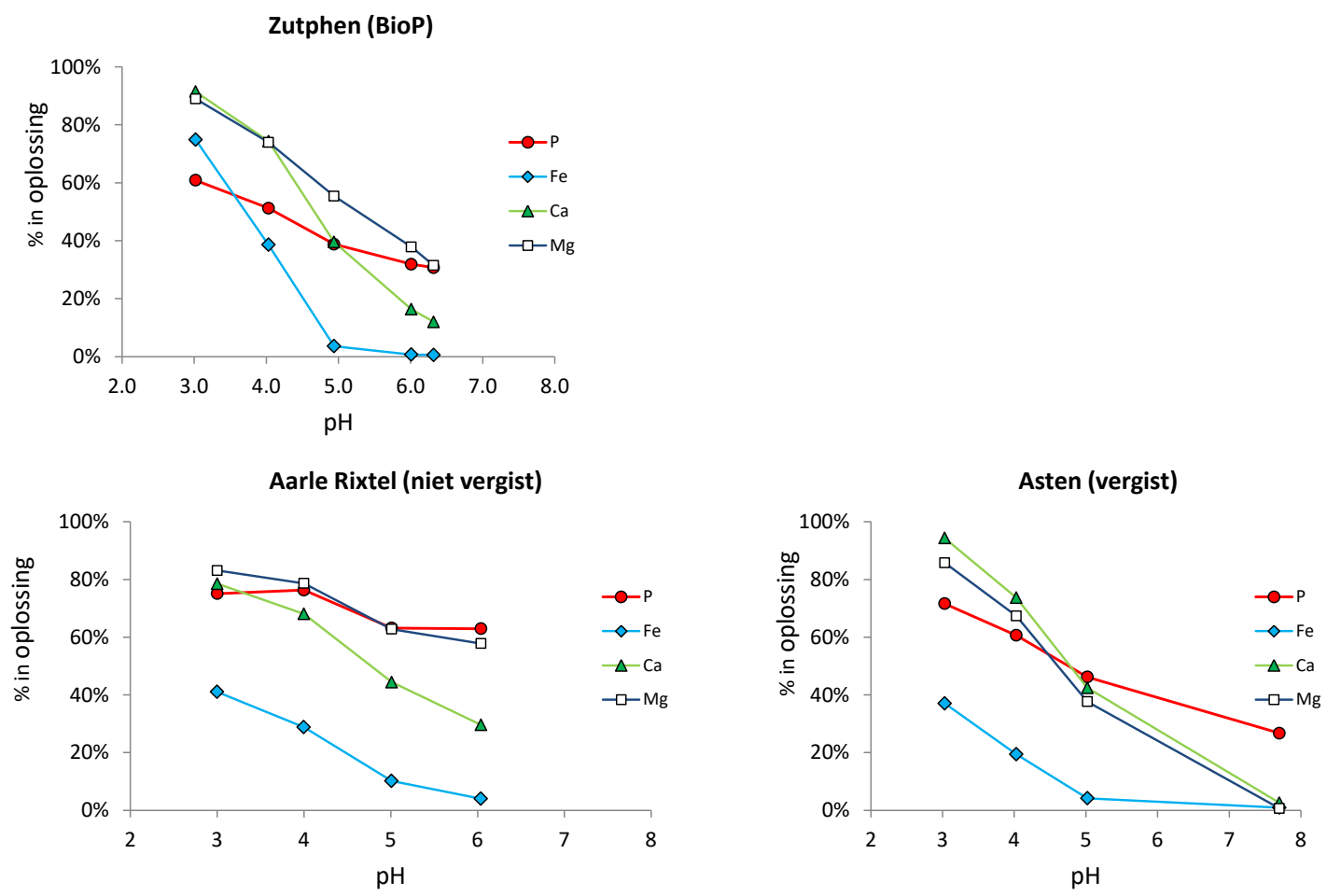

Figuur 4.9 Concentraties aan fosfaat (orthoP), ijzer, calcium en magnesium (mol/l) in de waterfase $(<0.45 \mu \mathrm{m}$ ) van het ingedikte slib als functie van de $\mathrm{pH}$ (na aanzuren met zwavelzuur) uitgedrukt als percentage van het totaalgehalte in slib.

Op RWZI Amsterdam is zuiveringsslib bemonsterd voor en na de struvietreactor. In het slibmonster genomen vóór de struvietreactor neemt het percentage fosfaat in de waterfase toe van 31\% (zonder aanzuren) tot $74 \%(\mathrm{pH} 3)$. Ná de struvietreactor kan circa $82 \%$ van het fosfaat opgelost worden door aanzuren tot $\mathrm{pH}$ 3. Het oplossen van magnesium toont aan dat inderdaad struvieten zijn gevormd die door aanzuren weer in oplossing worden gebracht. Het doseren van magnesium heeft dus geen negatief effect op de oplosbaarheid van het fosfaat in het zuiveringsslib dat niet in de vorm van struviet wordt afgescheiden. Het is dus mogelijk om het orthofosfaat te verwijderen in de struvietreactor en vervolgens het resterende fosfaat door middel van een zuur-baseprocedé terug te winnen.
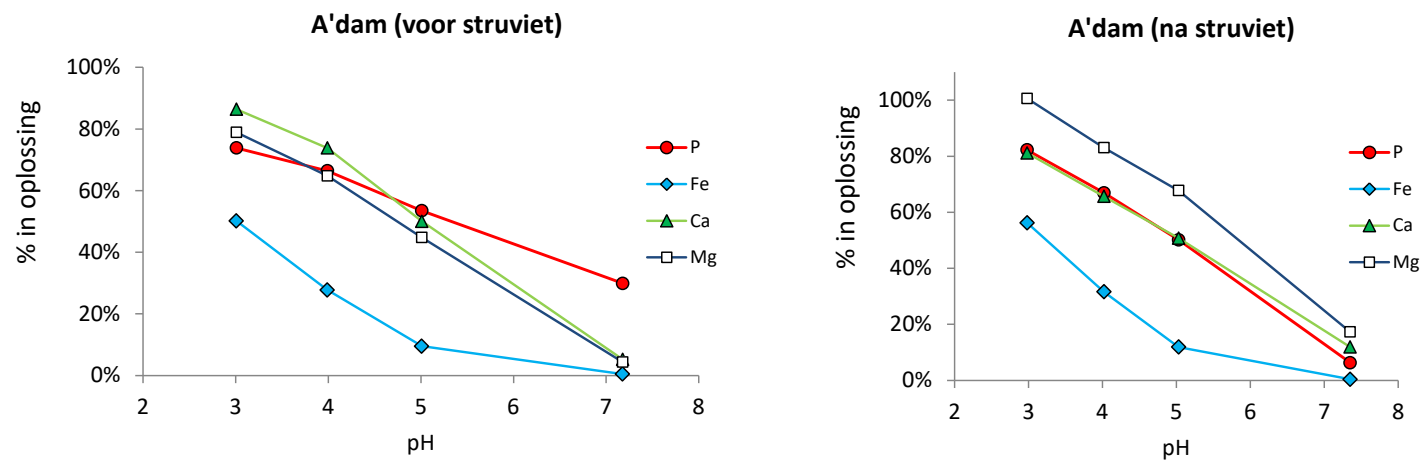

Figuur 4.10 Effect van pH op de concentratie (mol/l) aan fosfaat (orthoP), ijzer, calcium en magnesium in de waterfase $(<0.45 \mu \mathrm{m})$ van slib uitgedrukt als percentage van totaalgehalten, voor slib van RWZI Amsterdam voor (linker figuur) en na (rechter figuur) de struvietreactor. 


\subsubsection{Consequenties van ijzer- en aluminiumdoseringen op de RWZI}

Figuur 4.9 toont het percentage extraheerbaar fosfaat (na aanzuren tot $\mathrm{pH} 3$ ) als functie van de molaire Fe/P ratio van het slib. Voor ijzerarm slib (Fe/P $<0.4 \mathrm{~mol} / \mathrm{mol}$ ) kan 63 tot $72 \%$ van het fosfaat in oplossing gebracht worden door het slib aan te zuren tot $\mathrm{pH}$ 3. Dit percentage neemt af bij een toenemende $\mathrm{Fe} / \mathrm{P}$-ratio of, in het geval van aluminumdosering, $(\mathrm{Fe}+\mathrm{Al}) / \mathrm{P}$-ratio. Aluminium dat reeds aanwezig is in het influent van de RWZI heeft vrijwel geen effect op het vrijkomen van fosfaat. Dit blijkt uit het feit dat zeer hoge fosfaatextracties haalbaar zijn uit slib met aanzienlijke hoeveelheden aluminium afkomstig vanuit influent (o.a. Amsterdam). Dosering van ijzer- of aluminiumzouten heeft dus een negatief effect op de mogelijkheden om fosfaat uit slib te extraheren. De binding van fosfaat aan ijzer en aluminium is ook bij lage $\mathrm{pH}$ zeer stabiel. Het aanzuren van slib leidt alleen tot het oplossen van fosfaat wanneer de $\mathrm{pH}$ voldoende laag is om de Fe- of Al-hydroxide mineralen daadwerkelijk op te lossen. Zolang deze mineralen niet oplossen blijft fosfaat gebonden, omdat de adsorptiesterkte van fosfaat aan Fe- en Al-(hydr)oxiden juist toeneemt bij een afnemende $\mathrm{pH}$. Vergisten van slib verhoogt de oplosbaarheid van Fe waardoor de extractie gunstiger verloopt (zie RWZI Olburgen).

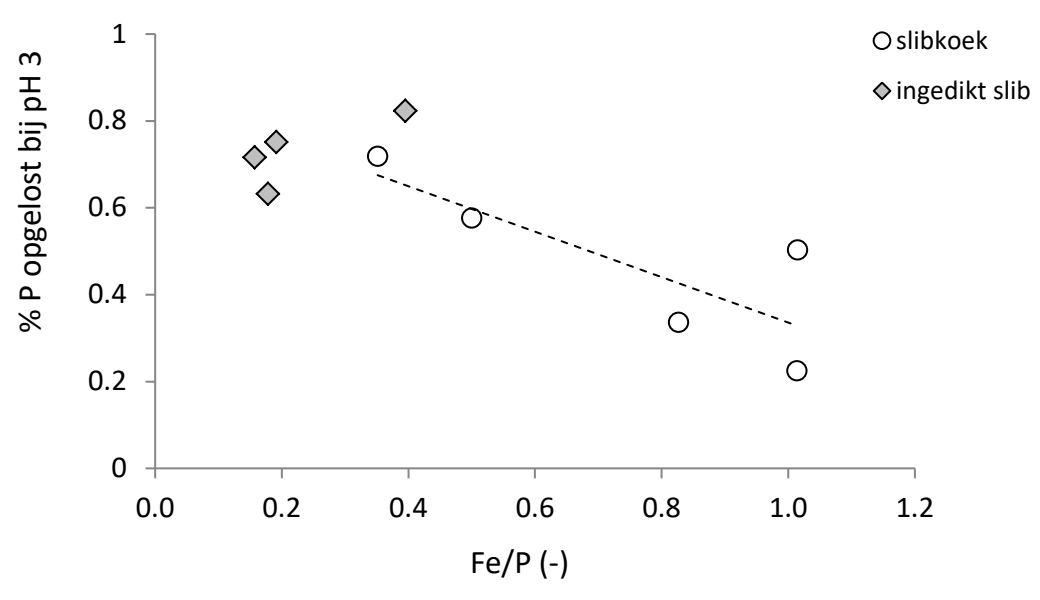

Figuur 4.11 Het percentage fosfaat (orthoP) in de waterfase ( $\%$ van totaal $P$ ) na aanzuren tot $p H$ 3 met zwavelzuur als functie van de Fe/P-ratio van de slibkoek of ingedikt slib (voor Oijen (Fe $+A l) / P$ ratio i.v.m. aluminiumdosering).

Bij de extractie van fosfaat uit ijzerhoudend slib wordt eveneens een deel van het ijzer geëxtraheerd. Dit ijzer zal met fosfaat neerslaan tijdens het terugwinnen van fosfaat met calcium of magnesium. Een hoog ijzergehalte in het herwonnen fosfaat beperkt de mogelijkheden tot het gebruik als meststof en verlaagt de afzetwaarde van het product. Als streefwaarde kan een Fe/P-ratio van $0.2 \mathrm{~mol} / \mathrm{mol}$ in het herwonnen fosfaat worden aangehouden. Figuur 4.10 toont de Fe/P-ratio's in de waterfase van slib van negen RWZI's na aanzuren tot $\mathrm{pH}$ 3. Deze verhouding is een goede indicator voor de Fe/P-ratio in het herwonnen fosfaat. De streefwaarde van $0.2 \mathrm{~mol} \mathrm{Fe} / \mathrm{mol} \mathrm{P}$ wordt alleen gehaald bij extractie op slib van RWZI's waar geen aanvullende ijzerdosering wordt toegepast. Op RWZI's waar wel ijzer wordt gedoseerd, zal de Fe/P-ratio in het herwonnen fosfaat hoger zijn dan 0.2. In dat geval kan het wenselijk zijn om de precipitatie van ijzer te voorkomen door ijzer te binden met citroenzuur of door ijzer te precipiteren met sulfide. 


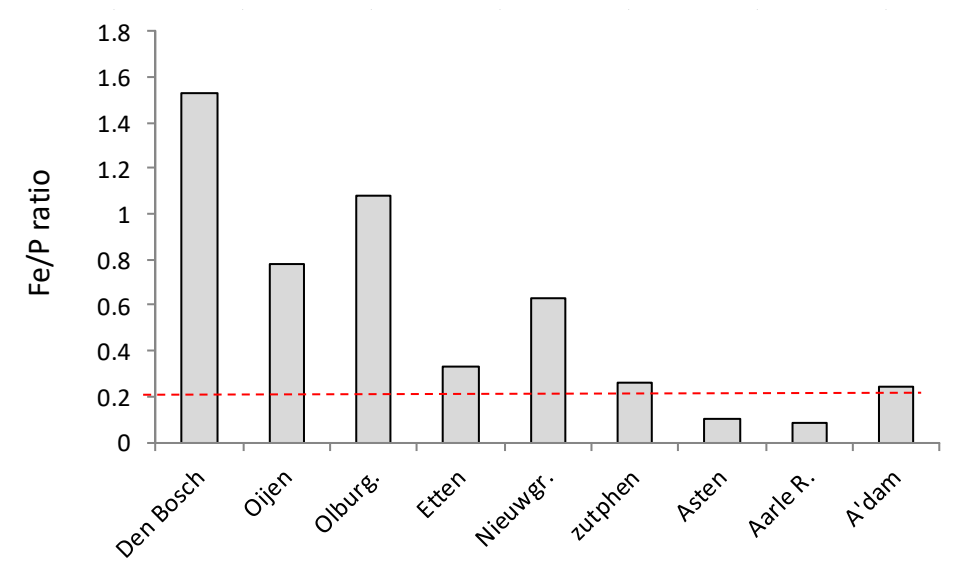

Figuur 4.12 Verhouding tussen ijzer en fosfaat (Fe/P, mol/mol) in de waterfase van zuiveringsslib na aanzuren met zwavelzuur tot $\mathrm{pH} 3$.

\subsubsection{Zuurdosering}

De resultaten van de zuurextracties zijn samegevat in Tabel 4.3. In deze paragraaf wordt de zuurdosering besproken in relatie tot de fosfaatopbrengst. Voor het aanzuren van ontwaterde slibkoek is 60 tot 145 liter zwavelzuur (96\%) per ton droge stof nodig. Dit komt overeen met 15 tot 36 liter zwavelzuur per ton slibkoek (bij 25\% droge stof). Bij de extractie op ingedikt slib is de zuurdosering, uitgedrukt per kilogram droge stof, vergelijkbaar (niet-vergist) of hoger (vergist) dan bij extractie op slibkoek. Na vergisten bevat de waterfase van het slib veel bicarbonaat. In dat geval heeft ontwateren een verlagend effect op het zuurbufferend vermogen. Door slib aan te zuren tot pH 3 kan $58-82 \%$ van het fosfaat in oplossing gebracht worden, mits de Fe/P-ratio lager is dan $0.5 \mathrm{~mol} / \mathrm{mol}$.

Bij de extractie van fosfaat uit slibkoek van RWZI's met biologische defosfatering bedraagt de zuurdosering 4,2-5,1 $\mathrm{mol} \mathrm{H} / \mathrm{mol} \mathrm{P}$. Bij extractie van fosfaat uit ingedikt slib is de molaire $\mathrm{H}^{+} / \mathrm{P}$-ratio laag bij extractie op niet-vergist slib $(2,0-3,2)$ en hoog bij extractie op vergist slib $(4,6-6,6)$. De hoge zuurdosering na vergisting is gerelateerd aan de vorming van bicarbonaat tijdens vergisting en kan zodoende verlaagd worden door het slib eerst verder in te dikken alvorens het slib aan te zuren. De zuurdosering per mol fosfaat zal dan aanzienlijk gunstiger uitvallen.

Ter vergelijking is ook de zuurdosering opgenomen bij extractie van fosfaat uit verbrandingsassen via het Ecophos-proces (phosphoric acid route) en bij extractie uit digestaat van varkensmest (Tabel 4.3). Bij de extractie van fosfaat uit ijzerarme verbrandingsassen bedraagt de zuurdosering 3,2 $\mathrm{mol} \mathrm{H}^{+}$per mol P (Jossa and Remy, 2015). Dit is vergelijkbaar met de zuurdosering voor zuiveringsslib van RWZI's zonder aanvullende ijzerdosering (2.0-4,6 mol/mol). Deze vergelijking laat zien dat de extractie van fosfaat in termen van zuurdosering dus kan concurreren met de extractie op verbrandingassen. De zuurdosering bij de extractie op digestaat van varkensmest is hoger dan voor ijzerarm slibkoek. Bij de extractie van fosfaat uit digestaat van varkensmest wordt de mest aangezuurd tot $\mathrm{pH} \mathrm{5,} \mathrm{omdat} \mathrm{dit} \mathrm{voldoende} \mathrm{is} \mathrm{om} \mathrm{alle} \mathrm{fosfaat} \mathrm{vrijwel} \mathrm{volledig} \mathrm{op} \mathrm{te} \mathrm{lossen} \mathrm{(geen} \mathrm{binding}$ aan ijzer of aluminium). De benodigde zuurdosering per kilogram droge stof is dan vergelijkbaar met slib. Echter, de zuurdosering per mol fosfaat is aanzienlijk hoger bij extractie op mest vanwege het lagere fosfaatgehalte van mest. Vanuit dit oogpunt is het duurzamer om fosfaten terug te winnen uit slib dan uit mest. 
Tabel 4.8 Slibsamenstelling, zuurdosering en orthoP in de waterfase na aanzuren bij extractie van fosfaat met zuur slibkoek, ingedikt slib, verbrandingsassen of dierlijke mest.

\begin{tabular}{|c|c|c|c|c|c|c|c|c|}
\hline \multirow[t]{2}{*}{ RWZI } & & \multirow[t]{2}{*}{ Vergist } & \multirow{2}{*}{$\begin{array}{l}\mathrm{Fe} / \mathrm{P} \\
(-)\end{array}$} & \multirow{2}{*}{$\begin{array}{l}\text { P-tot } \\
(\mathrm{g} / \mathrm{kg})\end{array}$} & \multicolumn{2}{|c|}{ Zuurdosering ${ }^{b}$} & \multirow{2}{*}{$\begin{array}{c}\text { P-opgelost }{ }^{a} \\
(\%)\end{array}$} & \multirow{2}{*}{$\begin{array}{c}\text { Mol } \mathrm{H}^{+} / \mathrm{mol} \mathrm{P}^{\mathrm{c}} \\
(-)\end{array}$} \\
\hline & & & & & (mol H+/kg ds) & (L/ton d.s) & & \\
\hline \multicolumn{9}{|c|}{ Slibkoek ( $\approx 25 \%$ droge stof) } \\
\hline Oijen $^{d}$ & $\mathrm{BioP}+\mathrm{Al}$ & Nee & $0,8^{e}$ & 23 & 2,3 & 115 & $34 \%$ & 8,6 \\
\hline Etten & $\mathrm{BioP}+\mathrm{Fe}$ & $\mathrm{Ja}$ & 0,4 & 30 & 2,9 & 145 & $72 \%$ & 4,2 \\
\hline Nieuwgraaf & $\mathrm{BioP}+\mathrm{Fe}$ & $\mathrm{Ja}$ & 0,5 & 31 & 2,9 & 145 & $58 \%$ & 5,1 \\
\hline \multicolumn{9}{|c|}{ Ingedikt slib ( $\approx 3 \%$ droge stof) } \\
\hline Zutphen & BioP & Nee & 0,20 & 34 & 2,2 & 110 & $61 \%$ & 3,2 \\
\hline Aarle-Rixtel & BioP & Nee & 0,15 & 32 & 1,6 & 80 & $75 \%$ & 2,0 \\
\hline \multicolumn{9}{|c|}{ Verbrandingsassen } \\
\hline Ecophos $^{f}$ & & & $<0.3$ & & & & $95 \%$ & 3,2 \\
\hline \multicolumn{9}{|c|}{ Dierlijke mest } \\
\hline Dikke fractie & vergiste vo & kensmest $^{g}$ & & 25 & 4,1 & 205 & $95 \%$ & 6,0 \\
\hline \multicolumn{9}{|c|}{ a OrthoP in de waterfase $(<0.45$ um) als percentage van P-totaal na aanzuren tot $\mathrm{pH} 3}$. \\
\hline \multicolumn{9}{|c|}{ b Zuurdosering per kilogram of ton droge stof. Zwavelzuur 96\% (10 $\left.\mathrm{M} \mathrm{H}_{2} \mathrm{SO}_{4}\right)$. } \\
\hline \multicolumn{9}{|c|}{ c $\mathrm{mol} \mathrm{H}^{+}$per mol fosfaat in oplossing na aanzuren. } \\
\hline \multicolumn{9}{|c|}{ d Voor Oijen $(\mathrm{Fe}+\mathrm{Al}) / \mathrm{P}$-ratio i.v.m. dosering van Al. } \\
\hline
\end{tabular}

\subsubsection{Extractie van zware metalen}

Bij het aanzuren van zuiveringsslib voor de extractie van fosfaat gaan zware metalen eveneens in oplossing. In deze paragraaf wordt besproken in welke mate zware metalen in oplossing gaan tijdens het extraheren van fosfaat met zwavelzuur en welke consequenties dit heeft voor de kwaliteit van het herwonnen fosfaat en de samenstelling van de resterende slibfractie.

Figuur 4.11 toont het percentage zware metalen in de waterfase na aanzuren van slib als functie van de $\mathrm{pH}$ voor slib van Den Bosch (niet-vergist) en Etten (vergist). Tabel 4.4 toont het percentage zware metalen dat in oplossing gaat na aanzuren van vergist en niet-vergist slib.

Binnen het geteste $\mathrm{pH}$-bereik leidt aanzuren van slib niet tot het in oplossing gaan van koper $(<0.1 \%)$. De zeer lage oplosbaarheid van koper wijst waarschijnlijk op de vastlegging van koper in de vorm van zeer stabiele kopersulfide(CuS)mineralen die gevormd worden onder anoxische en anaerobe condities. Voor zink leidt aanzuren van niet-vergist slib tot het in oplossing gaan van 16 tot $31 \%$ van de totale hoeveelheid zink in het slib. Echter, bij zuur-extractie na vergisting van slib neemt de oplosbaarheid van zink sterk af (2-8\%), waarschijnlijk eveneens door de vastlegging van $\mathrm{Zn}$ in de vorm van zeer stabiele zinksulfiden ( $\mathrm{ZnS}$ ). Voor nikkel leidt aanzuren tot het in oplossing gaan van 17-31\% van de totale hoeveelheid. Vergisting heeft geen effect op de oplosbaarheid van nikkel, doordat nikkelsulfiden zeer goed oplosbaar zijn. Aanzuren heeft ook nauwelijks effect op de oplosbaarheid van chroom $(<5 \%)$ en cadmium $(<0.1 \%)$.

Het extraheren van fosfaat uit zuiveringsslib draagt daarom bij aan het verlagen van zink- en nikkelgehalten in slib, maar heeft geen effect op de gehalten aan koper, chroom en lood in slib. De verlaging in zink na fosfaatextractie is echter niet voldoende om aan de norm voor zink te kunnen voldoen. Binnen het geteste pH-bereik biedt aanzuren dus geen perspectief om de gehalten aan zware metalen in slib in voldoende mate terug te dringen. 
Het (beperkt) in oplossing gaan van een aantal zware metalen tijdens de fosfaatextractie heeft ook consequenties voor de samenstelling van het herwonnen fosfaat. Naar verwachting zullen de geëxtraheerde zware metalen volledig worden opgenomen in het herwonnen fosfaatproduct. Daarom is de samenstelling van het herwonnen fosfaat geschat aan de hand van de gemeten concentraties aan zware metalen en fosfaat in de waterfase van het aangezuurde slib. In Tabel 4.5 wordt deze vergeleken met de norm voor zware metalen in herwonnen fosfaten zoals is opgenomen in het 'Uitvoeringsbesluit Meststoffenwet'. Hieruit blijkt dat er geen risico bestaat op het overschrijden van normen voor zware metalen in het herwonnen fosfaat.
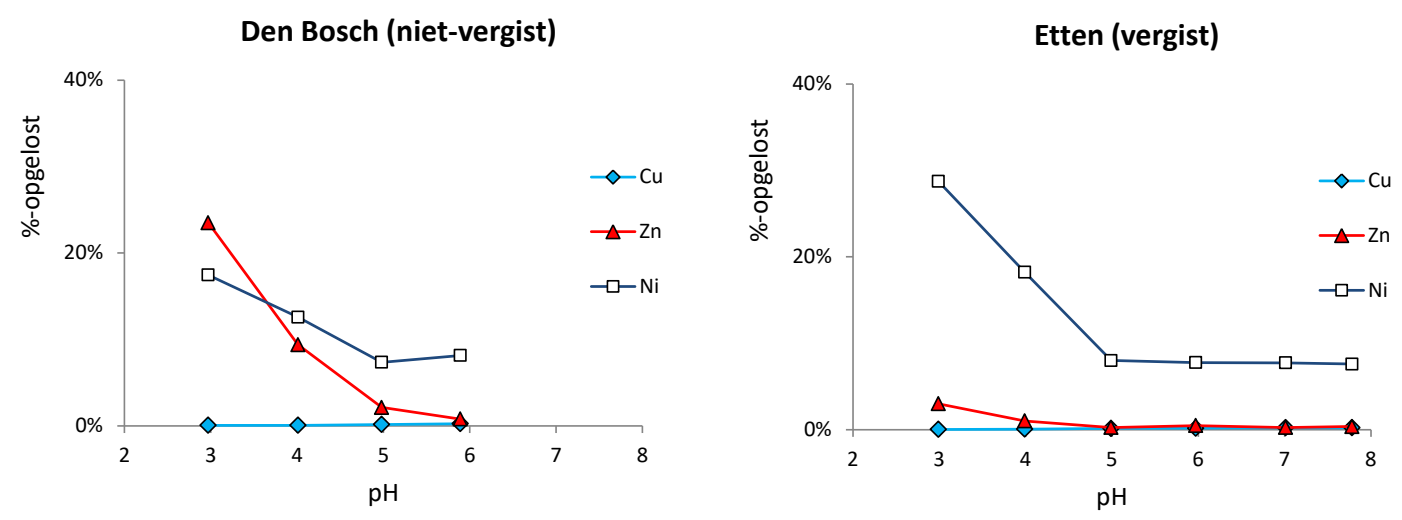

Figuur 4.13 Percentage koper, zink en in nikkel in oplossing na aanzuren met zwavelzuur voor vergist (Etten) en niet-vergist (Den Bosch) slib.

Tabel 4.9 Percentage zware metalen in oplossing na aanzuren van slib met zwavelzuur tot pH 3.0 voor vergist (Olburgen, Etten, Nieuwgraaf) en niet-vergist (Den Bosch, Zutphen, Oijen) slib ${ }^{1}$.

\begin{tabular}{lll} 
& $\begin{array}{l}\text { Niet-vergist slib } \\
(\% \text { totaal) }\end{array}$ & $\begin{array}{l}\text { Vergist slib } \\
(\% \text { totaal) }\end{array}$ \\
$\mathrm{Zn}$ & $16-31$ & $2-8$ \\
$\mathrm{Cu}$ & $<0.1$ & $<0.1$ \\
\hline $\mathrm{Ni}$ & 17 & $23-31$ \\
$\mathrm{Cr}$ & $2-5$ & $2-5$ \\
$\mathrm{Cd}$ & $<0.1$ & $<0.1$ \\
\hline
\end{tabular}

1 Nikkel en chroom zijn alleen bepaald in drie van zes locaties.

Tabel 4.10 Norm voor zware metalen in herwonnen fosfaten in mg per $\mathrm{kg}$ fosfaat (Uitvoeringsbes/uit Meststoffenwet) en schatting van de maximale gehalten in herwonnen fosfaat na zuur- en basedosering.

\begin{tabular}{lll} 
Element & Norm $(\mathrm{UBM})$ & $\begin{array}{l}\text { Herwonnen fosfaat (schatting) } \\
\mathrm{mg} / \mathrm{kg} \mathrm{P} \mathrm{O}_{5}\end{array}$ \\
$\mathrm{Cd}$ & 31.3 & $<0.3$ \\
\hline $\mathrm{Cr}$ & 1875 & $46-51$ \\
\hline $\mathrm{Cu}$ & 1875 & $5-36$ \\
\hline $\mathrm{Hg}$ & 18.8 & $\mathrm{n} . \mathrm{m} ;$ totaal $<$ norm \\
\hline $\mathrm{Ni}$ & 750 & $157-240$ \\
\hline $\mathrm{Pb}$ & 2500 & n.m; totaal<norm \\
\hline $\mathrm{Zn}$ & 7500 & $996-2554$ \\
\hline $\mathrm{As}$ & 375 & n.m; totaal<norm \\
\hline
\end{tabular}

a Chroom (Cr), nikkel (Ni), koper (Cu) en cadmium (Cd) zijn alleen bepaald in zuurextracten van slib van RWZI's Den Bosch, Etten en Olburgen. Kwik $(\mathrm{Hg})$, lood $(\mathrm{Pb})$ en arseen $(\mathrm{As})$ zijn niet bepaald in de zuurextracten. Voor deze zware metalen is getoetst uitgaande van een worstcasescenario waarbij deze metalen voor $100 \%$ in het herwonnen fosfaat terechtkomen. 


\subsubsection{Fosfaatextractie met citroenzuur of loog}

In deze paragraaf wordt een aantal alternatieven voor de extractie met zwavelzuur beschreven.

Zwavelzuur is een veelgebruikt zuur vanwege de lage kostprijs, maar het gebruik ervan zorgt voor een sulfaatrijke reststroom die door dosering van calcium of ijzer gezuiverd dient te worden. Als alternatief zijn extracties uitgevoerd met citroenzuur en loog.

\section{Extractie met citroenzuur}

Citroenzuur $\left(\mathrm{C}_{6} \mathrm{H}_{8} \mathrm{O}_{7}\right)$ is een mild zuur en een goede chelator voor $\mathrm{Ca}$, $\mathrm{Mg}$ en Fe. Citroenzuur is zeer goed biologisch afbreekbaar en een van de veiligste organische zuren om op industriële schaal mee te werken (Starmans and Melse, 2011). Het effect van citroenzuur op de extractie van fosfaat is getest op slib van RWZI Olburgen, Nieuwgraaf en Etten. Door de chelaat-vormende werking van het citroenzuur gaat fosfaat reeds bij een hogere $\mathrm{pH}$ in oplossing dan bij extractie met zwavelzuur (Figuur 4.13). Voor ijzerhoudend slib (Olburgen, Nieuwgraaf) kan met citroenzuur een hoger percentage fosfaat geëxtraheerd worden (74-75\%) dan met zwavelzuur (50-58\%). Voor het ijzerarme slib (Etten) wordt een vergelijkbaar percentage fosfaat geëxtraheerd met citroenzuur $(83 \%)$ en zwavelzuur (73\%).

Bij de extractie met citroenzuur worden naast fosfaat ook calcium, magnesium en ijzer in oplossing gebracht. Hoge ijzerconcentraties in de waterfase zijn ongewenst vanwege co-precipitatie van ijzer met het herwonnen fosfaat. Er zijn aanwijzingen dat deze co-precipitatie van Fe voorkomen wordt in de aanwezigheid van citroenzuur. Zo wordt in het Stuttgart-proces citroenzuur gedoseerd om Feprecipitatie tijdens struvietvorming te voorkomen (Jossa and Remy, 2015). Door de hoge extractieefficiëntie én het voorkomen van co-precipitatie van ijzer met fosfaat, kan het gebruik van citroenzuur zeer geschikt zijn voor terugwinning van fosfaat uit ijzerhoudend slib.

Om circa $75 \%$ van het fosfaat uit ijzerhoudend dan wel ijzerarm slib te extraheren, is een citroenzuurdosering nodig van $1050 \mathrm{mmol} / \mathrm{kg}$ droge stof of $220 \mathrm{gram}$ citroenzuur-dihydraat per kg droge stof. Bij het gebruik van commercieel beschikbaar citroenzuur ( $€ 900$,- per ton) resulteert dit in een kostenpost van circa $€ 50$,- per ton slibkoek. Voor een haalbare businesscase zou daarom gekeken moeten worden naar de mogelijkheden om te werken met combinaties van (goedkoop) zwavelzuur en citroenzuur, industriële reststromen met organische zuren ofwel het biologisch produceren van citroenzuur uit biomassa. 


\section{Olburgen}

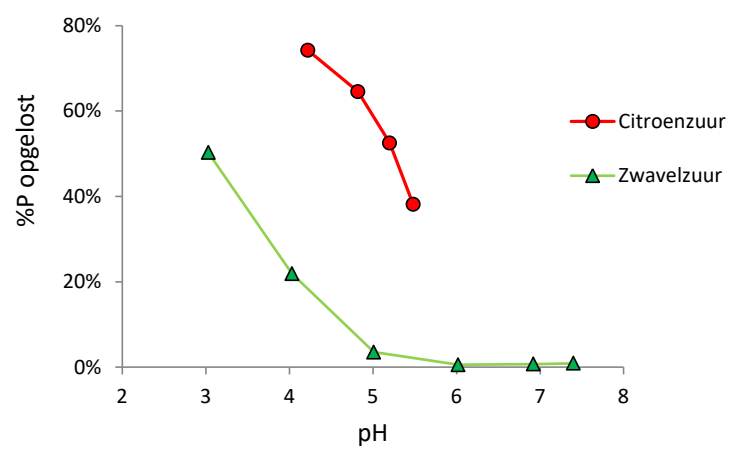

Nieuwgraaf

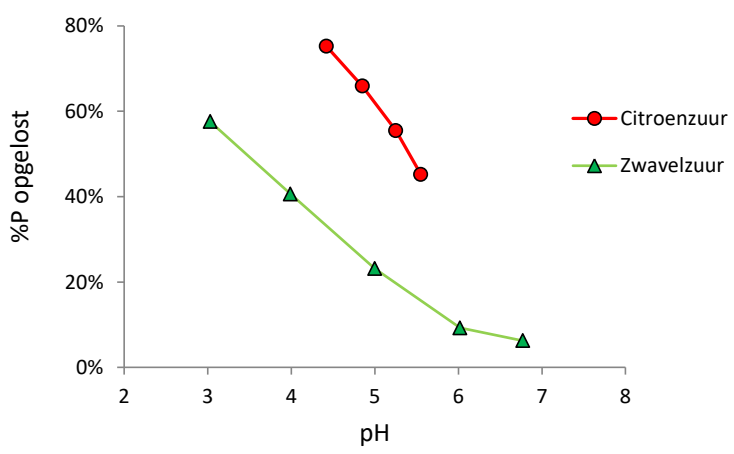

Etten

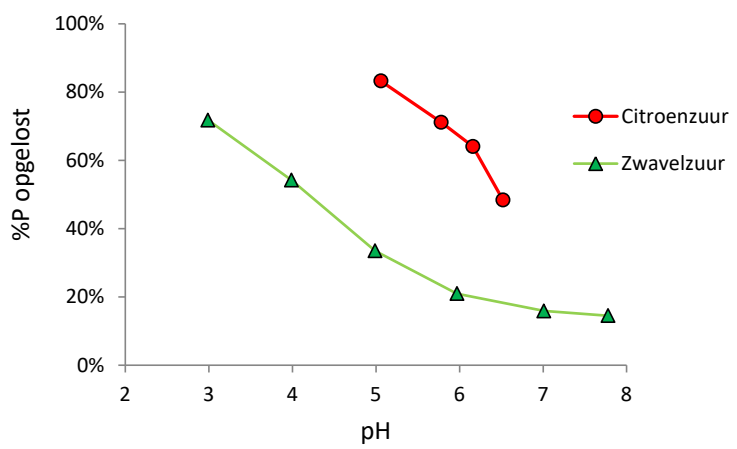

Olburgen

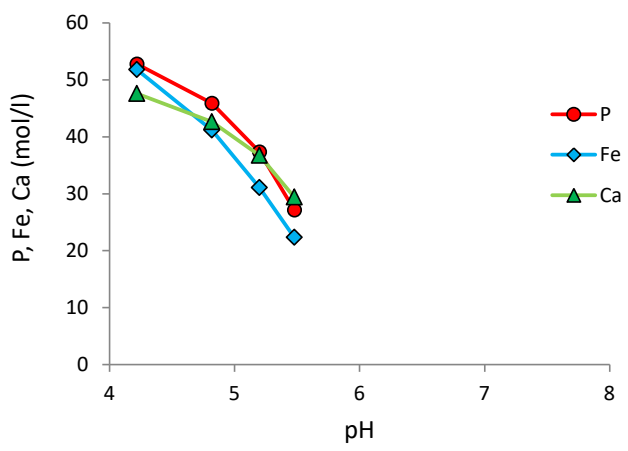

Nieuwgraaf

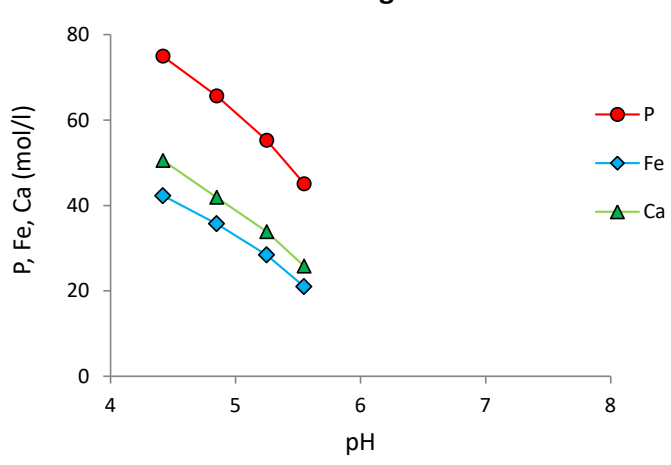

Etten

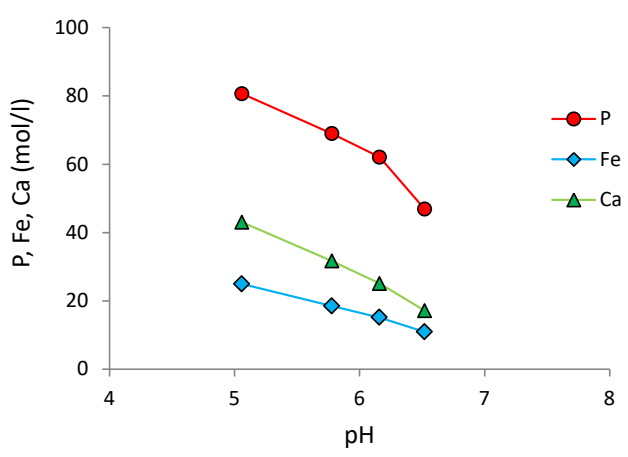

Figuur 4.14 Links: Percentage fosfaat in de waterfase van slib na aanzuren met zwavelzuur of citroenzuur. Rechts: Concentraties fosfaat, ijzer en calcium in de waterfase na dosering van citroenzuur. De laagste $\mathrm{pH}$-waarde komt overeen met een dosering van 220 gram citroenzuurdihydraat per $\mathrm{kg}$ droge stof.

\section{Extractie met loog}

$\mathrm{Er}$ is een extractie met loog $\left(\mathrm{Na}_{2} \mathrm{CO}_{3}\right)$ uitgevoerd om te testen of een pH-verhoging leidt tot het oplossen van calciumfosfaat (Figuur 4.14). Door de pH te verhogen, kan calcium in theorie worden vastgelegd in de vorm van calciumcarbonaat waardoor fosfaat in oplossing gaat. Echter, bij de geteste doseringen is slechts een lichte verhoging in de fosfaatconcentratie geconstateerd. Er is niet getest of een verdere $\mathrm{pH}$-verhoging leidt tot een hogere P-extractie, omdat dit zou leiden tot zeer hoge doseringen van soda (>250 gram $/ \mathrm{kg}$ d.s.). 


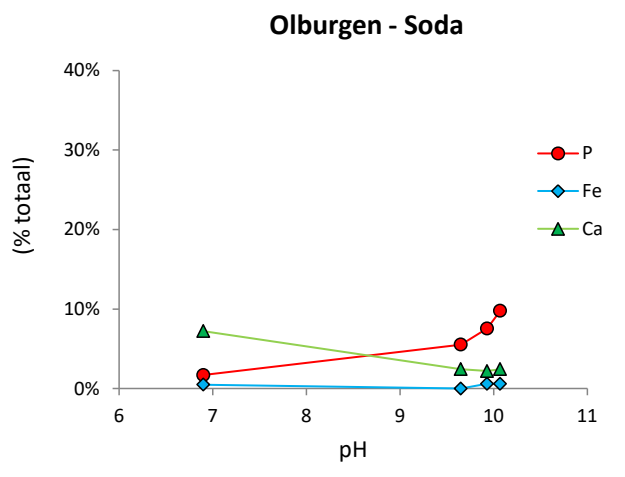

Figuur 4.15 Effect van $\mathrm{pH}$-verhoging door middel van $\mathrm{Na}_{2} \mathrm{CO}_{3}$-dosering op de $\mathrm{P}$-, Fe- en Caconcentratie in de waterfase van slibkoek (als \% van totaal).

\subsubsection{Effect van hydrothermale carbonisatie op fosfaatextractie}

Tabel 4.7 toont het percentage fosfaat in oplossing voor onbehandeld zuiveringsslib en slib na behandeling met Torwash- of hydrothermale carbonisatie. Hieruit blijkt dat er geen sprake is van een substantiële toename in de fosfaatconcentratie in de waterfase na Torwash- of hydrothermale carbonisatie. Voor zuiveringsslib met een initieel hoge $\mathrm{pH}(\mathrm{pH}>7,0)$ treedt een lichte verlaging op in de $\mathrm{pH}$-waarde na Torwash- en HTC-behandeling (resultaten niet opgenomen). Echter, van een sterk verzurend effect is geen sprake. Ook de mate van zuurbuffering, i.e. de hoeveelheid zuur dat gedoseerd dient te worden om het slib/hydrochar aan te zuren tot $\mathrm{pH}$, toont geen consequente afname na Torwash- of HTC-behandeling. Hydrothermale carbonisatie en Torwash leiden daarmee niet tot gunstigere condities voor extractie van fosfaat uit slib. Echter, de verbeterde ontwatering na hydrothermale behandeling kan een voordeel zijn, omdat er daardoor minder water en dus minder opgelost fosfaat achterblijft in de slibkoek na het afscheiden van de waterfase.

Tabel 4.11 Fosfaat in oplossing als percentage van het totale fosfaatgehalte en zuurbufferend vermogen ( $\mathrm{mol} \mathrm{\textrm {H } ^ { + }} \mathrm{kg}^{-1} \mathrm{ds}$ ) van zuiveringsslib en na Torwash- en HTC-behandeling ${ }^{a}$.

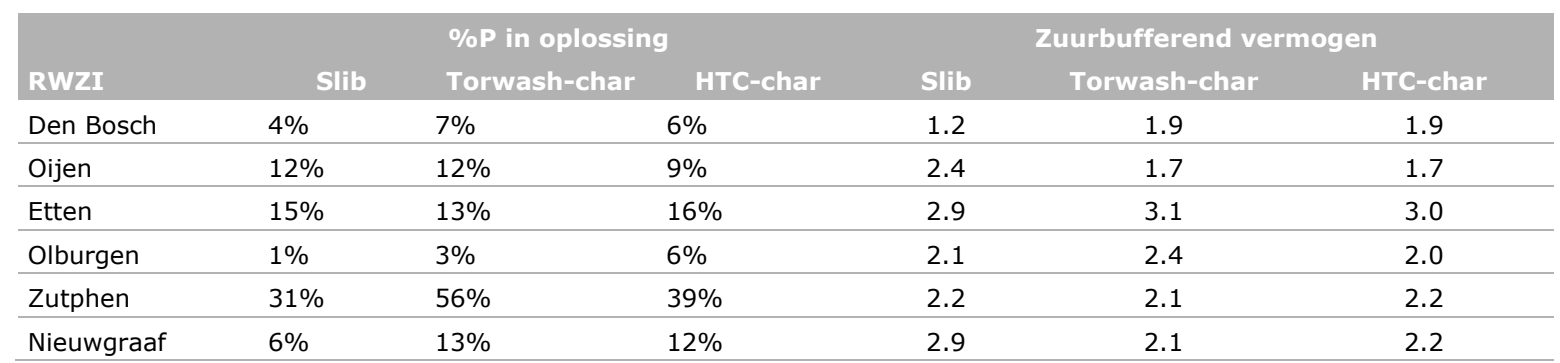

a Fosfaat in oplossing zonder aanzuren. Zuurbufferend vermogen is gedefinieerd als de hoeveelheid zuur, in mol $\mathrm{H}+/ \mathrm{kg}$ droge stof, die nodig is om slib of hydrochar aan te zuren tot $\mathrm{pH} 3,0$ bij gebruik van zwavelzuur.

\subsection{Perspectieven en kosten/baten}

Er zijn laboratoriumexperimenten uitgevoerd om de haalbaarheid van vergaande fosfaatextractie en terugwinning uit zuiveringsslib te kunnen beoordelen. Het doel was om het fosfaatgehalte met minimaal $75 \%$ te verlagen, zodat enerzijds een alternatief kan worden geboden voor de terugwinning van fosfaat uit verbrandingsassen en er anderzijds mogelijkheden ontstaan om fosfaat-verarmd slib in de landbouw af te zetten. In deze paragraaf worden de perspectieven en kosten/baten voor fosfaatextractie uit slib besproken. 
De experimenten, uitgevoerd op slib van negen RWZI's, laten zien dat het mogelijk is om circa 60$80 \%$ van het fosfaat uit zuiveringsslib in oplossing te brengen, mits de Fe/P-ratio in het slib lager is dan $0.4 \mathrm{~mol} / \mathrm{mol}$. Dit is haalbaar voor RWZI's waar fosfaat biologisch wordt verwijderd en geen of beperkt gebruik wordt gemaakt van aanvullende ijzerdosering. Bij een hoger ijzergehalte kan evenwel een substantieel deel van het fosfaat onttrokken worden, mits het slib eerst wordt vergist (omzetting $\mathrm{Fe}(\mathrm{III})$ naar Fe(II)) of wanneer citroenzuur wordt gedoseerd. Echter, perspectieven voor fosfaatextractie zijn gunstiger bij het gebruik van ijzerarm slib. Uit de Bedrijfsvergelijking zuiveringsbeheer blijkt dat 50\% van de RWZI's in Nederland geen metaalzouten gebruikt voor defosfatering en dat nog eens 10\% van de RWZI's minder dan $0.2 \mathrm{~mol} \mathrm{Fe} / \mathrm{mol}$ P doseert (Figuur 4.15). Op basis hiervan wordt geschat dat het slib van circa 50-60\% van de RWZI's aan de voorwaarden voor een lage Fe/P-ratio kan voldoen.

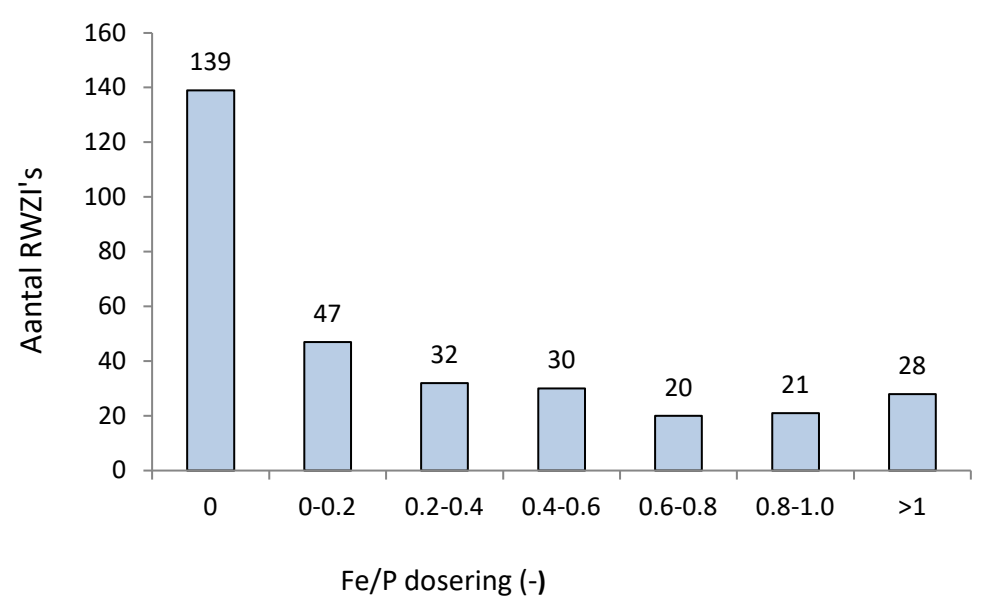

Figuur 4.16 Dosering van metaalzouten (ijzer of aluminium) op RWZI's (data Bedrijfsvergelijking Zuiveringsbeheer, 2015).

Figuur 4.16 toont een schematisch voorbeeld van een proces voor fosfaatextractie op vergist slib. Tabel 4.7 toont het verbruik van chemicaliën, opbrengst van producten en kosten voor chemicaliën. Hierbij is uitgegaan van extractie van fosfaat op vergist BioP-slib. Vergisting van slib heeft een klein positief effect op de mate waarin fosfaat geextraheerd kan worden, omdat vergisting leidt tot de omzetting van organisch naar anorganisch fosfaat. Door vergisting neemt het zuurbufferend vermogen van het slib toe door de productie van bicarbonaat. Door het slib te ontwateren, neemt het zuurbufferend vermogen af. Het ontwaterde slib wordt vervolgens aangelengd met water om extractie mogelijk te maken. Hiervoor kan bijvoorbeeld het rejectiewater gebruikt worden dat vrijkomt bij het indikken van slib voor vergisting. Dit water bevat reeds fosfaat en heeft naar verwachting een laag zuurbufferend vermogen.

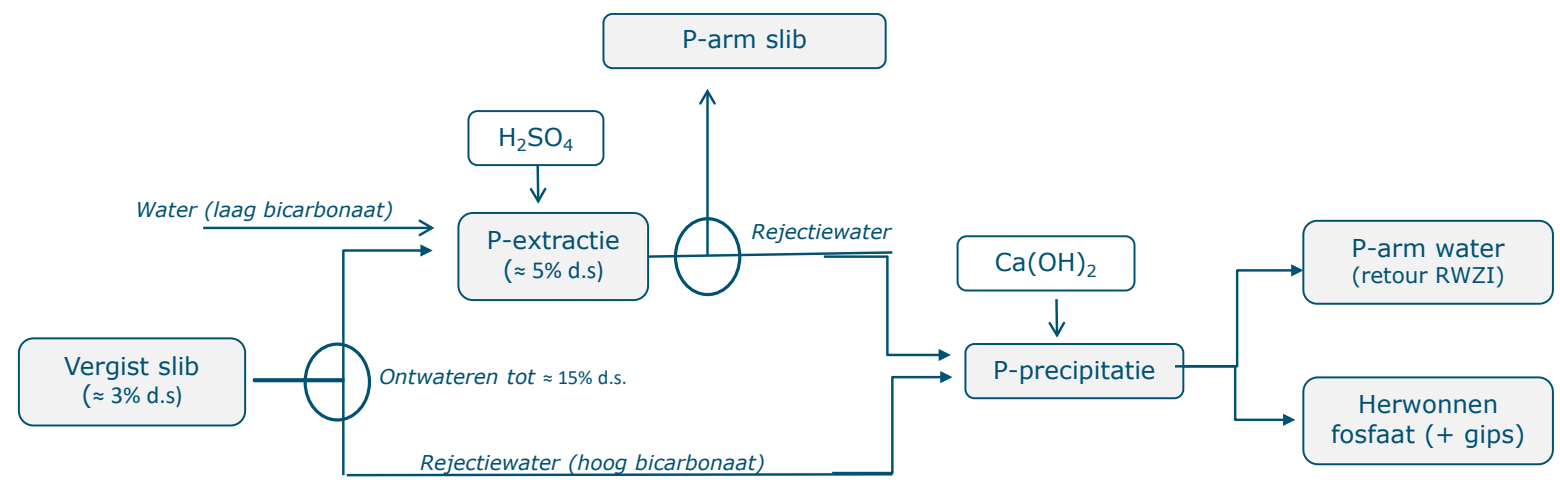

Figuur 4.17 Schema fosfaatextractie na vergisting. 
Voor het aanzuren van slib is een zuurdosering van $0.7 \mathrm{~mol} \mathrm{H^{+ }} / \mathrm{kg}$ slib nodig, wat overeenkomt met een dosering van $36 \mathrm{~L}$ zwavelzuur (96\%) per ton slibkoek. Hiermee kan tot $80 \%$ van het fosfaat in oplossing worden gebracht. Bij het scheiden (decanteren) van het aangezuurde slib zal circa $80 \%$ van het in oplossing gebrachte fosfaat worden afgescheiden in het rejectiewater. Het resterende deel blijft achter in de waterfase van de slibkoek. De vervolgstap, het terugwinnen van fosfaat uit de oplossing door dosering van kalkmelk, verloopt vrijwel volledig (Schoumans et al. 2017). Dit betekent dat netto circa $64 \%$ van het totale fosfaat $(80 \% * 80 \%)$ uit de slibkoek teruggewonnen kan worden. Voor het terugwinnen van fosfaat uit het rejectiewater moet calciumhydroxide (of magnesiumhydroxide) gedoseerd worden. De benodigde basedosering is niet experimenteel bepaald maar, op basis van gelijksoortige testen met dierlijke mest, kan geschat worden dat een basedosering van $0.5 \mathrm{~mol} \mathrm{OH}^{-} / \mathrm{kg}$ slibkoek ruim voldoende is. Dit komt overeen met een dosering van $17 \mathrm{~kg} \mathrm{Ca}(\mathrm{OH})_{2}(100 \%)$ per ton slibkoek. Bij gebruik van commercieel beschikbaar zwavelzuur en kalkmelk worden de kosten voor deze chemicaliën geschat op $€ 6$,- per ton slibkoek of $€ 24$,- per ton droge stof (Tabel 4.7).

Bij gebruik van zwavelzuur ontstaat een sulfaatrijke reststroom. Een deel van het sulfaat zal met het fosfaat precipiteren in de vorm bij gips. Een gips-houdende fosfaatmeststof kan worden afgezet naar de landbouw. Indien nodig kan het sulfaatgehalte verder verlaagd worden door de dosering van ijzerzout/ijzerslib. De kosten voor ijzerdosering zijn niet meegenomen in de kosten-batenanalyse. Er wordt aanbevolen om eveneens onderzoek te doen naar alternatieve methoden voor het aanzuren van slib waarbij een hoge sulfaatbelasting wordt voorkomen.

Een deel van de kosten kan worden terugverdiend vanuit de opbrengst van het herwonnen fosfaat. Per ton slibkoek kan circa 4,8 kg P (11 kg $\left.\mathrm{P}_{2} \mathrm{O}_{5}\right)$ worden teruggewonnen, wat overeenkomt met circa $50 \mathrm{~kg}$ calciumfosfaat- of struvietproduct uitgaande van $22 \% \mathrm{P}_{2} \mathrm{O}_{5}$. Voor struviet is recentelijk de economische marktwaarde geschat op $€ 55$,- per ton struviet (Evers et al. 2016). De geschatte realistische marktwaarde is daarmee aanzienlijk lager dan de theoretische waarde van het product op basis van huidige kunstmestprijzen ( $€$ 350,- per ton struviet, Evers et al. 2016). Echter, omdat de afzetmarkt voor herwonnen fosfaatmeststoffen binnen Nederland zeer beperkt is, is afzet als grondstof voor kunstmestproductie realistischer. Het product dient in dat geval als vervanger van fosfaaterts, wat een waarde kent van circa $€ 60$ per ton $\left(33 \% \mathrm{P}_{2} \mathrm{O}_{5}\right)$. Zodoende wordt de marktwaarde van het herwonnen fosfaat bij afzet als grondstof geschat op $€ 40$,- per ton bij 22\% $\mathrm{P}_{2} \mathrm{O}_{5}$ afgeleverd bij de gebruiker. De transportkosten bedragen circa $€ 10$,- euro per ton product. Struviet heeft veelal een zeer hoog drogestofgehalte (tot 98\%, Evers et al. 2016) waardoor struviet met een nettowinst van $€$ 30,- per ton kan worden afgezet. Voor de vorming van struviet wordt gebruikgemaakt van opstroomreactoren. Het is ook mogelijk om fosfaat terug te winnen met goedkopere lowtech-methoden (kalkmelkdosering en bezinking) waarbij een calciumfosfaatproduct ontstaat met een lager drogestofgehalte (Schoumans et al. 2017) waardoor de transportkosten toenemen. Voor deze eerste inschatting van de kosten/baten is aangenomen dat fosfaat wordt teruggewonnen in de vorm van een product met $50 \%$ droge stof, wat betekent dat er na aftrek van de transportkosten een kleine nettowinst overblijft van $€ 20$,- per ton droge stof.

Andere voordelen van vergaande fosfaatverwijdering zijn de afname in de slibmassa en de verbeterde ontwatering. Wanneer $65 \%$ van het totale fosfaat uit slib te verwijderen is, neemt het fosfaatgehalte op drogestofbasis af met $60 \mathrm{~g} \mathrm{PO}_{4} / \mathrm{kg}$. Oftewel het extraheren van fosfaat resulteert in $6 \%$ afname in de slibmassa. Bij een poorttarief van $€ 65$ per ton slibkoek levert dit een besparing op van $€ 3,90$ per ton slibkoek. Daarnaast kan verwacht worden dan het aanzuren van slib een positief effect heeft op de slibontwatering. Dit effect is beschreven in literatuur (Chen et al. 2001) en ook in de prakrijk wordt wel gebruikgemaakt van zuurdosering bij slecht ontwaterbaar slib. Dit betekent dat, naast de absolute afname in slibmassa, ook een voordeel is te behalen door besparing op kosten voor polymeer. Uit Tabel 4.7 blijkt dat de kosten voor chemicaliën grotendeels opwegen tegen de verwachte besparing op kosten voor slibafvoer, waardoor de nettokosten circa $€ 1$,- per ton slibkoek bedragen. Voordelen door besparing op polymeer en verdere operationele kosten en afschrijving van de installaties zijn niet meegenomen in deze analyse.

Door fosfaat reeds op de RWZI uit het slib terug te winnen, vervalt de noodzaak om slib te verwerken in een monoverbrandingsinstallatie teneinde fosfaatterugwinning mogelijk te maken. Als alternatief kan zuiveringsslib biologisch dan wel met restwarmte worden gedroogd en afgezet als biobrandstof. 
De afzet van slib als biobrandstof wordt aantrekkelijker na vergaande fosfaatverwijdering, omdat de hoeveelheid asresten substantieel afneemt. Bij onbehandeld slib (Tabel 4.2) bestaat de asfractie na volledige verbranding voor circa $11 \%$ uit fosfor $(P)$ en dus voor circa $48 \%$ uit fosfaathoudende mineralen (o.a. $\mathrm{CaHPO}_{4}$ ). Wanneer deze calciumfosfaten voor $65 \%$ worden verwijderd, neemt de hoeveelheid verbrandings-as af met ruim $30 \%$. Hierdoor zal de marktwaarde van gedroogd slib als biobrandstof toenemen.

Tabel 4.12 Indicatieve kosten en baten voor de extractie en terugwinning van fosfaat uit ijzerarm slib uitgedrukt per ton droge stof en per ton slibkoek (25\% droge stof) ${ }^{1}$.

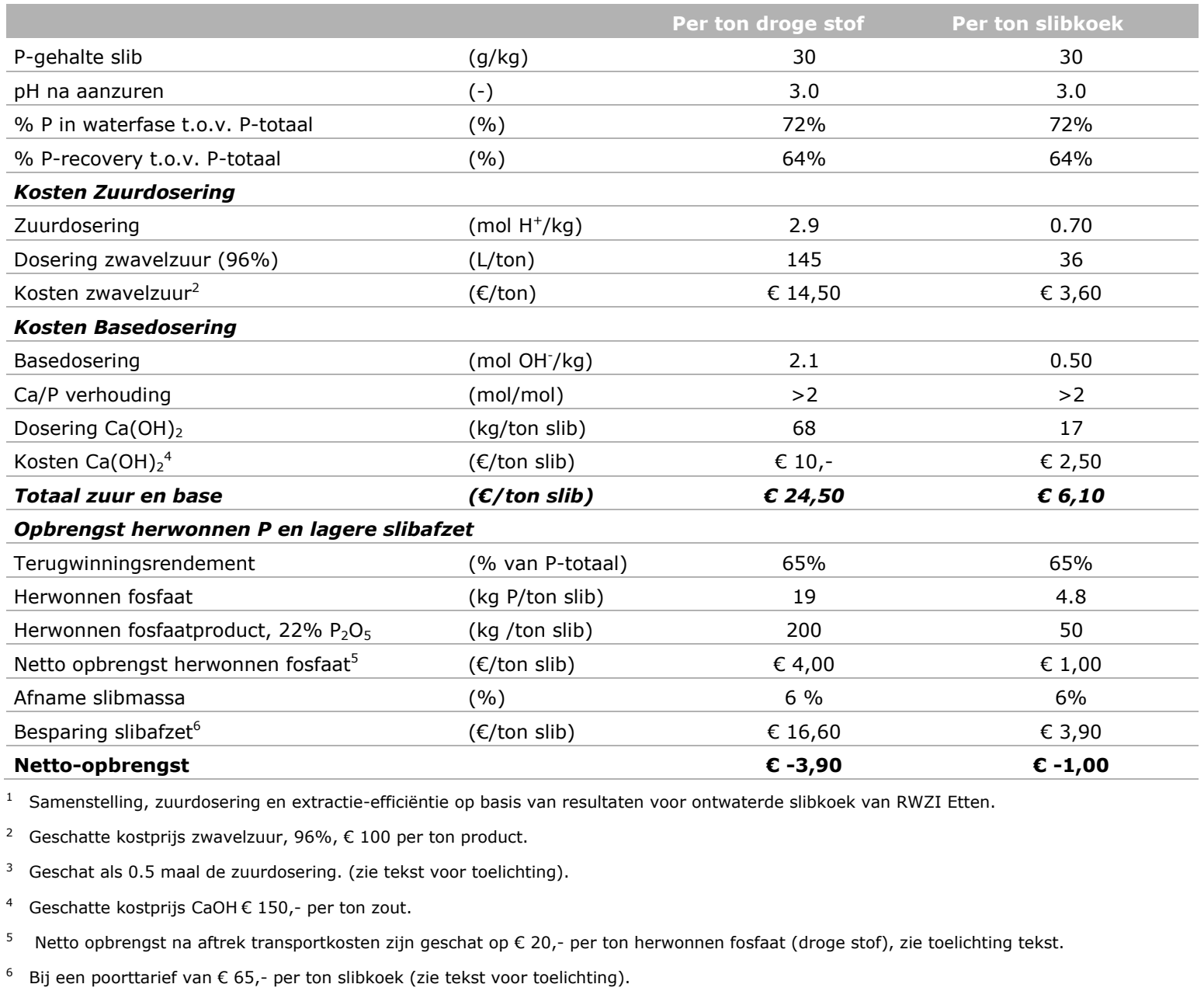




\subsection{Conclusies}

- Fosfaat in slib is grotendeels gebonden in de vorm van calciumfosfaat (bij biologische defosfatering) of neergeslagen met ijzer/aluminium (bij chemische defosfatering). Polyfosfaten worden tijdens opslag of vergisting volledig gehydrolyseerd tot orthofosfaat.

- Het zuurbufferend vermogen van zuiveringsslib neemt toe na vergisting door de vorming van bicarbonaat. Dit effect kan tenietgedaan worden door slib te ontwateren waardoor het bicarbonaatrijke water wordt verwijderd.

- Calcium- en magnesiumfosfaten lossen nagenoeg volledig op ( $\approx 95 \%)$ na aanzuren van slib met zwavelzuur tot $\mathrm{pH}$ 3. IJzergebonden fosfaat lost deels op en aluminiumgebonden fosfaten en organisch fosfaat lossen niet op.

- Voor ijzerarm slib ( Fe/P <0.4) kan $72-82 \%$ van het fosfaat uit slib in oplossing gebracht worden door het slib met zwavelzuur aan te zuren tot $\mathrm{pH}$ 3. Naar schatting kan 60-65\% van het P-totaal uit slibkoek daadwerkelijk afgescheiden en teruggewonnen worden.

- Zware metalen gaan niet of beperkt (zink, nikkel) in oplossing na aanzuren van slib met zwavelzuur tot $\mathrm{pH}$ 3. Er is zodoende geen risico voor overschrijding van normen voor zware metalen in het herwonnen fosfaatproduct. De beperkte mobilisatie van metalen na aanzuring betekent echter ook dat met dit procedé geen substantiële kwaliteitsvetering van slib m.b.t. gehalten aan zware metalen gerealiseerd kan worden.

- Bij fosfaatextractie uit ijzerarm slib is de zuurdosering per mol winbaar fosfaat vergelijkbaar met die bij verbrandingsassen en lager dan bij dierlijke mest.

- Organische zuren, met name citroenzuur, kunnen een gunstig alternatief zijn voor zwavelzuur. Aanbevolen wordt om verder onderzoek te doen naar mogelijkheden voor gebruik van organische zuren uit reststromen, productie van organische zuren uit biomassa en biologische verzuring.

- Voor de extractie van fosfaat uit ijzerarm slib is circa $36 \mathrm{~L} \mathrm{H}_{2} \mathrm{SO}_{4}$ en $17 \mathrm{~kg}\left(\mathrm{Ca}(\mathrm{OH})_{2}\right.$ per ton slibkoek nodig. De kosten voor het verbruik van deze chemicaliën worden geschat op $€ 6$,- per ton slibkoek.

- Na vergaande fosfaatverwijdering is de slibmassa met circa 6\% afgenomen. Tevens wordt verwacht dat het aanzuren leidt tot een verbeterde ontwatering en daardoor besparing op polymeerverbruik.

- Bij verbranding van fosfaatarm slib ontstaat $40 \%$ minder asresten dan bij onbehandeld slib. Dit kan de afzetmogelijkheden van gedroogd slib als biobrandstof verhogen. 


\section{$5 \quad$ Milieurisicobeoordeling zware metalen}

\section{$5.1 \quad$ Inleiding}

Zuiveringsslib bevat diverse verontreinigingen, waaronder zware metalen. Om de accumulatie van zware metalen in landbouwgronden te voorkomen, zijn de maximale dosering en maximaal toelaatbare gehalten aan zware metalen in zuiveringsslib vastgelegd in het Uitvoeringsbesluit Meststoffenwet. De dosering en maximaal toelaatbare gehalten zijn afgeleid op basis van een voorzorgsprincipe waarbij als uitgangspunt is gehanteerd dat er na 100 jaar bemesting met zuiveringsslib geen toename in gehalten aan zware metalen in de bodem mag zijn opgetreden. Daarom is de maximale vracht aan zware metalen (dosering maal gehalte) gelijk gesteld aan de gemiddelde jaarlijkse afvoer van zware metalen via het gewas en uitspoeling (TCB, 1989; 1991). Destijds zijn dezelfde uitgangspunten gehanteerd voor het afleiden van normen voor compost en andere meststoffen (m.u.v. dierlijke mest). Echter, deze bodemverbeteraars en meststoffen (nietzijnde zuiveringsslib) vallen vanaf 2018 onder de nieuwe EU-Meststoffenverordening (Hoofdstuk 2) waarin vooralsnog geen normen voor koper en zink zijn opgenomen, maar wel voorstellen daartoe onderwerp van discussie zijn. In de nieuwe meststoffenverordeningen worden koper en zink vooralsnog niet gereguleerd, omdat deze beschouwd worden als micronutriënten. Voor zuiveringsslib blijven echter de door lidstaten geformuleerde normen van kracht, omdat slib expliciet is uitgesloten als meststof met een CE-markering.

In Nederland hebben landbouwgronden te maken met (deels historische) belasting van zware metalen (inclusief koper en zink) door de bemesting met kunstmest (relevant voor cadmium), dierlijke mest (relevant voor met name koper en zink) en compost (relevant voor onder meer lood en deels andere metalen). Dierlijke mest vormt daarbij verreweg de grootste bron ( $>80 \%$ van de totale belasting) in de belasting van landbouwbodems met koper en zink. De bijdrage van atmosferische depositie is, vergeleken met de andere bronnen, klein. Gehalten aan zware metalen in dierlijke mest worden niet gereguleerd. Koper en zink worden aan mengvoeders toegevoegd vanwege de positieve effecten op diergezondheid. Deze zware metalen worden echter ook weer grotendeels uitgescheiden na inname via voer en water, waardoor dierlijke mest hoge gehalten aan koper en zink bevat (Römkens en Rietra, 2012). Doordat het gebruik van dierlijke mest grotendeels de behoefte aan fosfaat in de landbouw dekt, is het gebruik van kunstmest ten behoeve van fosfaat relatief klein. Daardoor is de belasting van de landbouwbodem met cadmium uit kunstmest in Nederland beperkt. Voor stikstof- en kalimeststoffen geldt dat de gehalten aan zware metalen in deze producten laag zijn en de belasting verwaarloosbaar is ten opzichte van die uit dierlijke mest en compost.

Door de langdurige belasting van de bodem met vooral koper en zink is er regionaal sprake van een netto-accumulatie in de bodem. Doordat de toxiciteit van koper en zink in de bodem voor de meeste gewassen pas bij zeer hoge gehalten in de bodem merkbaar wordt, zijn de effecten van deze accumulatie voor de landbouw als zodanig gering. Een uitzondering daarop vormen de verhoogde gehalten aan koper in grasland voor schapen. Voor deze vorm van landbouw is er regionaal sprake van een overschrijding van de advieswaarden en de mate van overschrijding zal bij voortgaand gebruik van dierlijke mest toenemen. Daarbij moet worden opgemerkt dat de herkomst van het koper in de gronden met verhoogde gehalten aan koper (veelal veengronden) deels historisch is (aanvoer van stedelijk afval sinds de Middeleeuwen en daarna) en niet zozeer door de aanwending van mest. Negatieve effecten van de accumulatie van zware metalen in de bodem uiten zich op dit moment voornamelijk in een verhoogde uitspoeling van zware metalen naar grond- en oppervlaktewater. In gebieden met hoge grondwaterstanden is de uitspoeling van zware metalen toegenomen als gevolg van de accumulatie in de bodem met bemesting als belangrijkste bron. In de overige delen van Nederland leveren metalen van natuurlijke oorsprong nog steeds de belangrijkste bijdrage aan uitspoeling (Bonten, 2010). Vanuit milieukundig opzicht is de uitspoeling van metalen momenteel het belangrijkste knelpunt als het gaat om de aanvoer van metalen naar de (landbouwbodem). Tot voor kort vond de beoordeling van de waterkwaliteit plaats op basis van totaalgehalten, wat in een groot 
deel van Nederland leidde tot normoverschrijding voor koper en zink. Echter, nu koper en zink door middel van de tweedelijnsbeoordeling getoetst kunnen worden op basis van de biobeschikbaarheid voor organismen i.p.v. louter de totaalconcentraties, is het aantal overschrijdingen van koper- en zinkgehalten in oppervlakten aanzienlijk lager. Juist omdat de belasting van de bodem met zware metalen vanuit dierlijke mest ook in de nabije toekomst ongewijzigd blijft én aanvoer via mest kwantitatief de grootste bijdrage levert aan de belasting voor de meeste metalen, is er in dit project voor gekozen om de impact van het gebruik van slib in eerste instantie te beoordelen ten opzichte van de impact bij het gebruik van dierlijke mest. Als uitgangspunt is gehanteerd dat de introductie van slibproducten in de landbouw niet mag leiden tot een toename in de uitspoeling van zware metalen uit landbouwgronden ten opzichte van referentiescenario's met bemesting met dierlijke mest.

Bij de beoordeling van de toelaatbaarheid van slib is de totale hoeveelheid metalen in slib (en bodem in geval van berekende veranderingen in het gehalte) sturend. Deze totale hoeveelheid, vaak bepaald met sterk zure extracties als Koningswater (Aqua Regia), is echter in veel gevallen niet maatgevend voor de beschikbaarheid en daarmee voor de effecten van metalen in de bodem. Deze beschikbare hoeveelheid is in veel gevallen maar een deel van de totale hoeveelheid. Recentelijk is een evaluatie uitgevoerd van de huidige methodiek waarmee risico's van zware metalen in de bodem - en daaruit voortvloeiende te nemen maatregelen - beoordeeld worden. Hierin zijn ook voorstellen gedaan voor mogelijke concepten voor verbetering daarvan die meer rekening houden met het aspect van (bio)beschikbaarheid van stoffen in de bodem (Lijzen et al. 2015). Hoewel deze evaluatie nog niet heeft geleid tot concrete voorstellen met betrekking tot nieuwe normen, gaan we in dit rapport wel in op de mate waarin een keuze voor normering op basis van beschikbaarheid ruimte kan scheppen voor het gebruik van slib en verwerkt slib in de landbouw. Daarbij vergelijken we niet alleen de mate van beschikbaarheid in slib zelf ten opzichte van die in de bodem, maar ook of de verwerking van slib door vergisten, composteren of hydrothermale carbonisatie leidt tot een verandering van de beschikbaarheid van zware metalen en welke consequenties dit heeft voor een veilig gebruik van (verwerkte) slibproducten in de landbouw.

\subsection{Modelbeschrijving, materiaal en methoden}

\subsubsection{Modelbeschrijving milieurisicobeoordeling}

Voor de milieurisicobeoordeling is gerekend met de gemiddelde samenstelling van mest, slib en compost. Voor de samenstelling dierlijke mest is gebruikgemaakt van gemiddelde gehalten in varkensmest en rundermest (Romkens en Rietra, 2008). Voor de samenstelling van zuiveringsslib is gerekend met de gemiddelde samenstelling van slib in Nederland volgens data van het CBS. Voor GFT- en groencompost is gerekend met gemiddelde waarden zoals gepubliceerd door de BVOR (2014).

Op basis van de samenstelling van de meststof en de dosering wordt de totale jaarlijkse vracht aan zware metalen berekend. De dosering van organische meststof is, overeenkomstig de praktijk, berekend als de maximaal toegestane dosering onder de fosfaatgebruiksnorm behorende bij bouwland met een neutrale fosfaattoestand (60 kg $\mathrm{P}_{2} \mathrm{O}_{5} / \mathrm{ha}$ ). De aanvoer van zware metalen via aanvullende minerale $\mathrm{N}$ meststof en kalk is niet meegenomen in de berekening. 


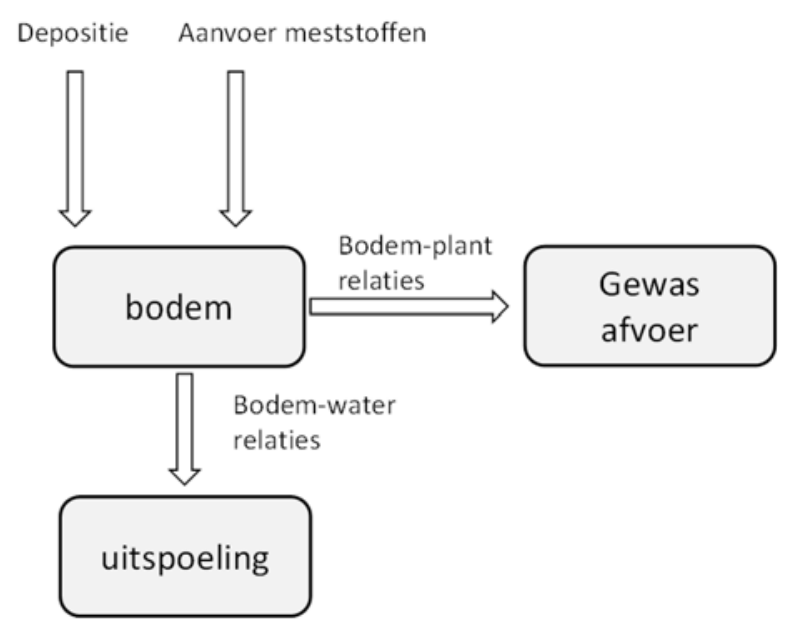

Figuur 5.1 Modelmatige aanpak voor het berekenen van de effecten van de dosering van zware metalen op gehalten in bodem en gewas en op uitspoeling.

De jaarlijkse vrachten aan zware metalen zijn gebruikt als input voor het dynamische model waarin de verdeling van zware metalen over bodem, water en plant wordt berekend (Figuur 5.1). Dit model bestaat uit de volgende onderdelen:

- De initiële gehalten aan zware metalen $\left(t_{0}\right)$ zijn gelijk aan de achtergrondwaarden per bodemtype. Voor de algemene bodemeigenschappen is gebruikgemaakt van de gemiddelde samenstelling van Nederlandse gronden per bodemtype (Tabel 5.1). De jaarlijkse input van zware metalen vanuit meststof wordt berekend op basis van de dosering en samenstelling.

- De concentraties van zware metalen in het bodemvocht worden berekend op basis van partitierelaties en bodemeigenschappen die de binding van zware metalen aan de bodemmatrix beïnvloeden (organische stofgehalte, kleigehalte en pH) (Römkens et al. 2004). De uitspoeling van zware metalen wordt berekend op basis van de concentraties in het bodemvocht en een neerslagoverschot van $340 \mathrm{~mm}$ per jaar.

- Gehalten aan zware metalen in het gewas worden deels berekend op basis van gewas-specifieke bodem-plantrelaties en deels op basis van constante gehalten in het gewas indien geen relatie tussen de gehalten in de bodem en gewas kan worden aangetoond (Römkens et al 2007). De jaarlijkse afvoer van zware metalen via gewas wordt berekend uitgaande van gemiddelde opbrengsten voor het betreffende landbouwgewas en de berekende gehalten aan zware metalen.

- De jaarlijkse accumulatie van zware metalen in de bodem wordt berekend als het verschil tussen input (meststoffen) en output (uitspoeling en gewasopname). Hieruit worden de gehalten aan zware metalen op $t_{x+1}$ berekend, waarna de berekening voor het daaropvolgende jaar wordt uitgevoerd.

De modelberekening is uitgevoerd voor een zandgrond en mariene kleigrond. De gemiddelde samenstelling en achtergrondwaarden voor zware metalen in deze twee grondsoorten staan getoond in Tabel 5.1. Voor gewassen is gekozen voor een rotatie van mais, suikerbiet en tarwe.

Tabel 5.1 Gemiddelde samenstelling van zand-en mariene kleigronden in Nederland ${ }^{1}$. Input dynamische modellering.

\begin{tabular}{|c|c|c|c|c|c|c|c|c|c|c|c|}
\hline & Cd & $\mathrm{Cr}$ & $\mathrm{Cu}$ & $\mathrm{Hg}$ & $\mathbf{N i}$ & $\mathrm{Pb}$ & $\mathrm{Zn}$ & As & Klei & os & pH \\
\hline & - & & & & $\mathrm{g} / \mathrm{kg}$ & & & -- & $\%$ & $\%$ & \\
\hline Zand & 0.19 & 21 & 7.2 & 0.04 & 1.5 & 17.4 & 19.5 & 2.6 & 6.6 & 4.7 & $5.8^{2}$ \\
\hline
\end{tabular}

1 Bron: De geochemische atlas van Nederland (Mol et al. 2010).

2 De mediane $\mathrm{pH}$ van zandgronden is 4.7 (inclusief natuurgronden); echter voor landbouwgronden kan aangenomen worden dat de $\mathrm{pH}$ tussen $\mathrm{pH} 5$ en $\mathrm{pH} 6$ ligt. 


\subsubsection{Materiaal en methoden - reactiviteit zware metalen}

Op zes RWZI's is slibkoek (na ontwatering) bemonsterd. Deze monsters zijn eveneens gebruikt voor het testen van de fosfaatextractiemethode in hoofdstuk 4. Voor een beschrijving van de herkomst en samenstelling van de slibmonsters wordt verwezen naar Tabel 4.1 en 4.2.

Om het effect van hydrothermale carbonisatie op de beschikbaarheid van zware metalen te beoordelen, zijn de zes slibmonsters in een labopstelling gedurende $120 \mathrm{~min}$. behandeld bij $200{ }^{\circ} \mathrm{C}$ en een druk van circa 20 bar. Voor verdere details en samenstelling van het slib na hydrothermale carbonisatie wordt verwezen naar paragraaf 4.2.5.

Bij GMB BioEnergie in Zutphen is biogranulaat bemonsterd. Dit is het eindproduct na vergaande compostering (biologisch drogen) van zuiveringsslib. Voor de samenstelling van dit biogranulaat wordt verwezen naar Tabel 3.2.

Alle bovengenoemde slibproducten zijn geanalyseerd op totaalgehalten en beschikbare gehalten aan zware metalen. De monsters zijn eerst bij $105^{\circ} \mathrm{C}$ gedroogd en gemalen alvorens de analyses zijn uitgevoerd. Totaalgehalten aan zware metalen zijn bepaald na een magnetrondestructie met Aqua Regia. Reactieve zware metalen zijn bepaald na extractie in $0.43 \mathrm{M} \mathrm{HNO}_{3}$ (schudverhouding $0.1 \mathrm{~kg} / \mathrm{L}$ ) met een schudtijd van twee uur. De extracten van beide bepalingen zijn na filtratie geanalyseerd op zware metalen met behulp van ICP-AES en ICP-MS. De analyses zijn uitgevoerd door het Chemisch Biologisch Laboratorium Bodem te Wageningen (geaccrediteerd).

\subsection{Resultaten}

\subsubsection{Trends in gehalten aan zware metalen in slib}

De samenstelling van communaal zuiveringsslib is sinds de jaren tachtig grosso modo sterk verbeterd (Figuren 5.2). Gehalten aan zink, koper en nikkel zijn in de jaren tachtig gedaald en daarna stabiel gebleven. Lood, chroom, cadmium en kwik zijn sterk gedaald sinds de jaren tachtig en de dalende trend lijkt voor deze metalen nog steeds door te zetten. Gehalten aan arseen zijn daarentegen licht gestegen. In dezelfde periode is het gemiddelde organische stofgehalte toegenomen van 58 tot $68 \%$ en het fosfaatgehalte is toegenomen van $23 \mathrm{~g} / \mathrm{kg}$ tot $33 \mathrm{~g} / \mathrm{kg}$. De belasting met zware metalen uitgedrukt per gewichtseenheid van de waarde-gevende bestanddelen is dus voor de meeste metalen sinds 1980 afgenomen. 

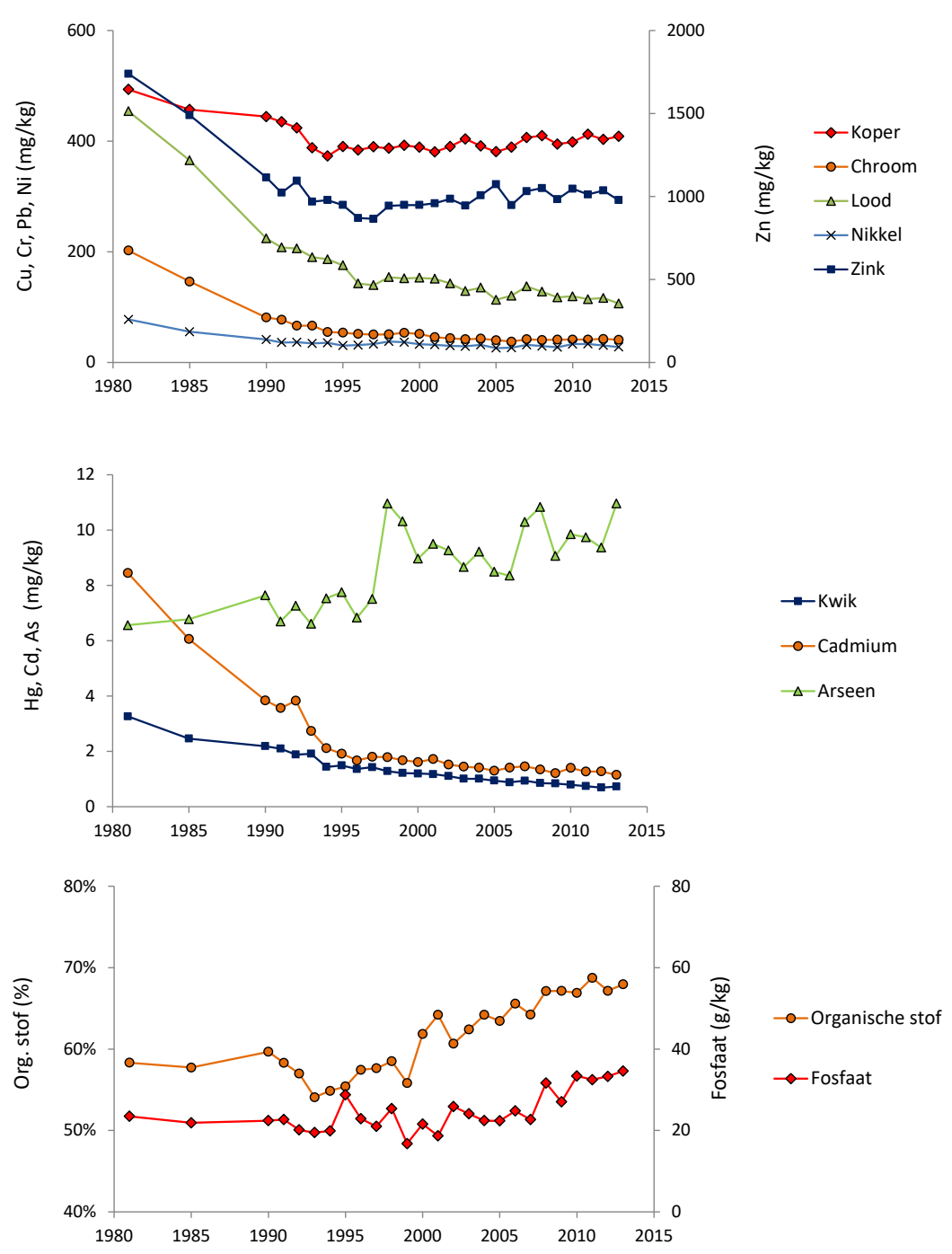

Figuur 5.2 Trends in gehalten aan zware metalen, organische stof en fosfaat in zuiveringsslib in de periode 1980-2014 (CBS, 2016).

\subsubsection{Gehalten aan zware metalen in slib}

Tabel 5.2 geeft de gemiddelde samenstelling weer van zuiveringsslib, biogranulaat, dierlijke mest en compost, evenals de huidige NL-normen voor zuiveringsslib (UBM). De spreiding in gehalten aan zware metalen is weergegeven in Figuur 5.3 op basis van data van 35 RWZI's. Bij toetsing aan de normen vormen koper en zink de grootste knelpunten. Slib van alle RWZI's overschrijdt daarbij de normen voor koper en zink: de gemiddelde koper- en zinkgehalten liggen respectievelijk een factor 5 en 3 boven de norm. Voor de overige zware metalen $(\mathrm{Cr}, \mathrm{Ni}, \mathrm{As}, \mathrm{Cd}, \mathrm{Hg}, \mathrm{Pb}$ ) geldt dat, met uitzondering van lood, het gemiddelde slib aan de norm van het UBM voldoet. Op individueel RWZIniveau zijn er echter wel overschrijdingen. Zo worden de normen voor chroom, lood en nikkel in respectievelijk $15 \%, 15 \%$ en $25 \%$ van de RWZI's overschreden (Figuur 5.3 ). Chroom- en arseengehalten in slibkoek liggen onder de norm, met uitzondering van twee RWZI's waar industriële lozingen resulteren in zeer hoge $\mathrm{Cr}$ - (leerlooierij) of As- (visafslag) gehalten. Bij de afzet van slib naar de landbouw zou het slib van deze uitzonderlijke locaties niet geschikt zijn voor toepassing. In biogranulaat zijn de gehalten aan zware metalen licht verhoogd ten opzichte van die in het oorspronkelijke slib, doordat een deel van de organische stoffractie verloren gaat tijdens het composteren. Hierdoor worden naast koper en zink ook lood, cadmium en chroom een knelpunt bij de beoordeling van biogranulaat. Gehalten voor kwik en arseen liggen rond de norm. 
In 2016 heeft de Europese Commissie een voorstel voor een nieuwe meststoffenverordening gepubliceerd. Vanaf 2018 kunnen organische meststoffen (zuiveringsslib uitgesloten) onder voorwaarden van de meststoffenverordening vrij verhandeld worden als meststof met een CE-markering. Wanneer zuiveringsslib volgens de ontwerpnormen voor toekomstige CE-meststoffen wordt beoordeeld, dan zou de gemiddelde samenstelling van Nederlands zuiveringsslib aan de ontwerpnormen voor zware metalen voldoen (Tabel 5.2).

Tabel 5.2 Gehalten aan nutriënten en zware metalen in slib, fosfaat-verarmde slibproducten, biogranulaat, dierlijke mest en compost zoals gebruikt in de risicomodellering.

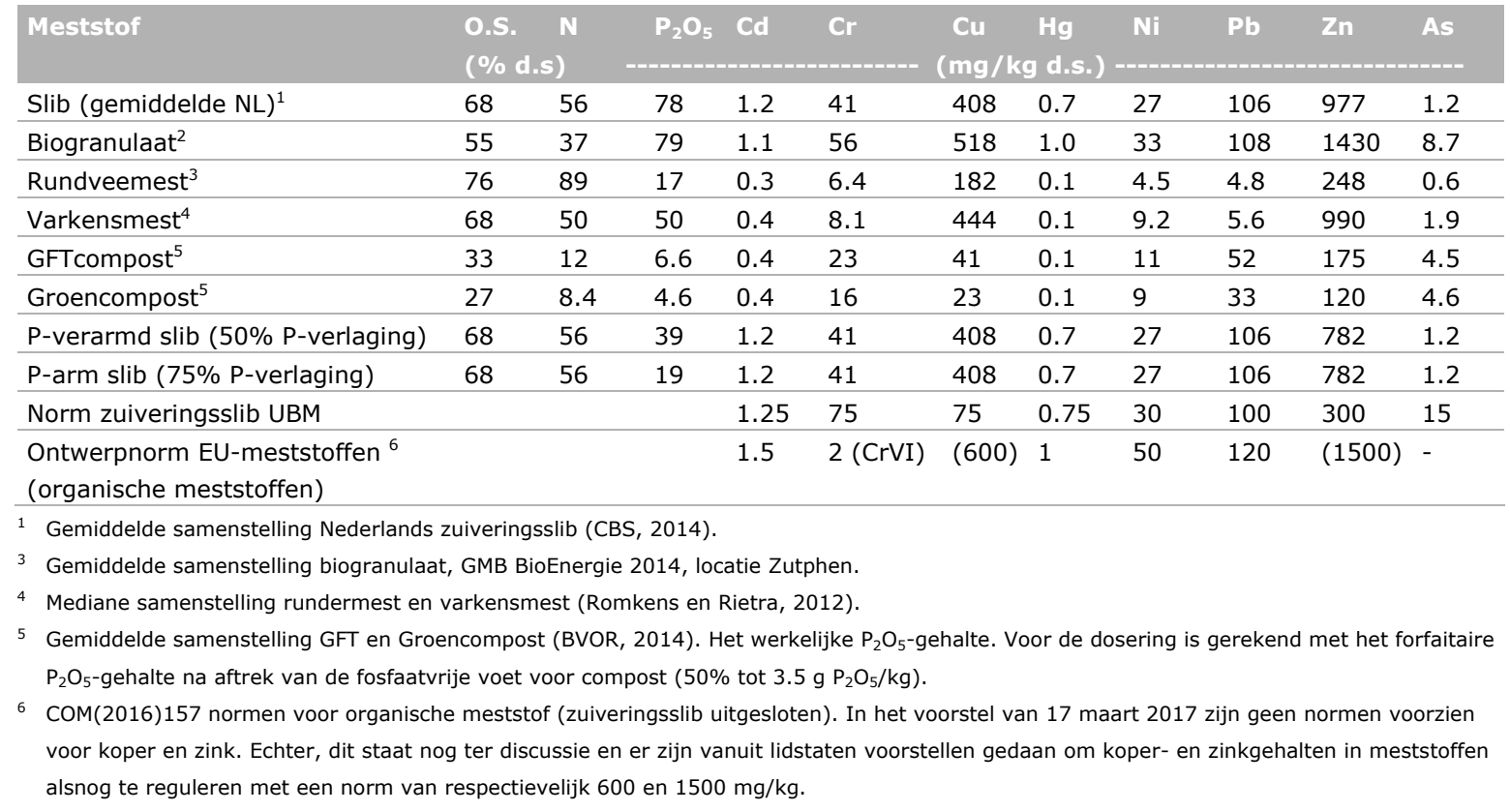

Ofschoon de gehalten aan koper en zink volgens het UBM niet voldoen aan de normen, komen de gehalten voor zowel koper als zink op gewichtsbasis overeen met die in dierlijke mest, en dan vooral met die in varkensmest (Tabel 6.2). Voor andere zware metalen, m.u.v. arseen, is dierlijke mest aanzienlijk schoner dan slib en/of slibcompost. In tegenstelling tot slib(compost) kenmerkt GFTcompost zich door aanzienlijk lagere gehalten aan koper en zink. De verschillen in gehalten aan zware metalen tussen de verschillende meststoffen kunnen echter niet zonder meer vergeleken worden op basis van de gehalten per kilogram droge stof van het product. Immers, vanwege de grote verschillen in $\mathrm{P}-, \mathrm{N}$ - en organische stofgehalte zal iedere meststof met een andere dosering worden toegepast. De belasting van de bodem met zware metalen is dus afhankelijk van de dosering van het product en de inpassing in het bemestingsplan. Dit wordt verder in dit hoofdstuk toegelicht.
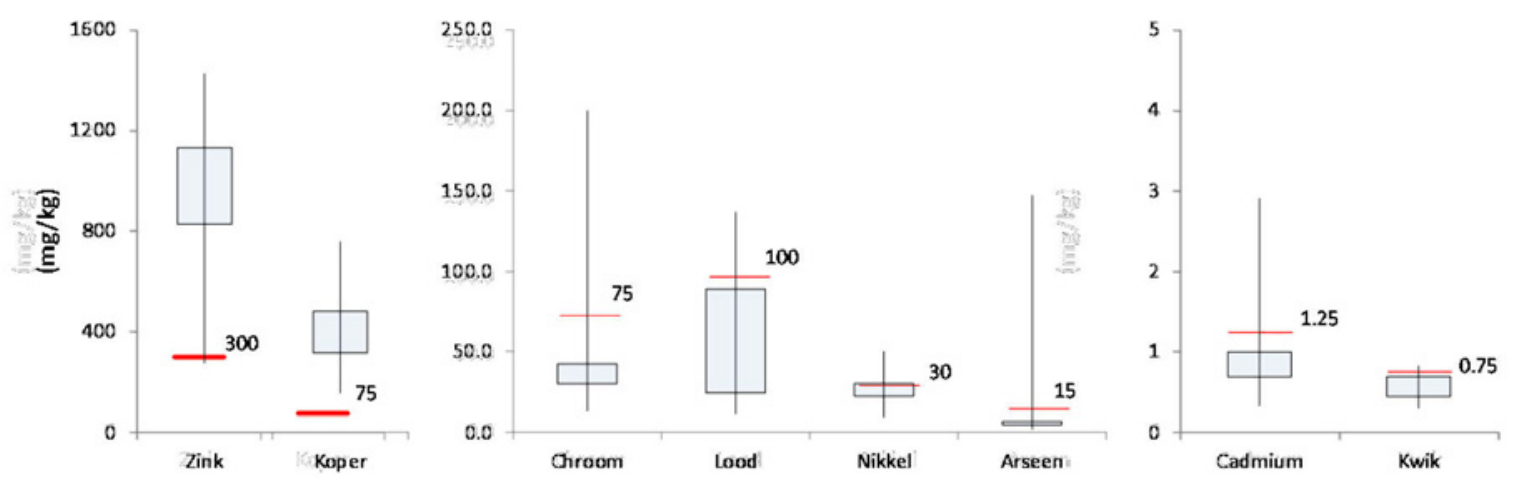

Figuur 5.3 Spreiding in gehalten aan zware metalen op basis van data van slib van 35 RWZI's (staaf: P25-P75, lijn: Min-Max). De rode lijn toont de norm voor zuiveringsslib zoals opgenomen in het UBM. 
Tussen RWZI's zijn er zeer grote verschillen in koper- en zinkgehalten in slib (Figuur 5.3). Dit roept de vraag op of het mogelijk is om de markt te betreden met relatief 'schone' slibstromen door alleen die stromen te selecteren waarin zowel het koper- als het zinkgehalte onder de gemiddelde waarde liggen. Echter, koper- en zinkgehalten in zuiveringsslib correleren in veel gevallen niet met elkaar (Figuur 5.4), wat de mogelijkheden tot het selecteren van 'schone' slibstromen beperkt. Voor circa $25 \%$ van de RWZI's ligt zowel het koper- als het zinkgehalte lager dan die in de gemiddelde slibmonsters. Voor deze $25 \%$ schonere slibstormen bedraagt het gemiddelde koper- en zinkgehalte echter respectievelijk 285 en $685 \mathrm{mg} / \mathrm{kg}$, wat voor beide metalen nog steeds ruim boven de norm is. Directe afzet van slib in de landbouw lijkt daardoor, op basis van de normen zoals nu opgenomen in het UBM, niet mogelijk. Gezien de vergelijkbare gehalten aan beide metalen in varkensdrijfmest en de aanwending zonder beperking t.a.v. metaalgehalten daarvan, kan dan de vraag gesteld worden of de beoordeling van de kwaliteit van slib vanuit een aanvaardbare belasting van de bodem zinvol is.

Figuur 5.5 toont de regionale verschillen in gehalten aan koper en zink in communaal zuiveringsslib. Koper- en zinkgehalten in slib uit de provincie Flevoland zijn grofweg een factor twee lager dan de gemiddelde gehalten in Nederlands slib. Ook in Friesland is het zuiveringsslib relatief schoon met koper- en zinkgehalten die respectievelijk $23 \%$ en $18 \%$ lager zijn dan gemiddeld.

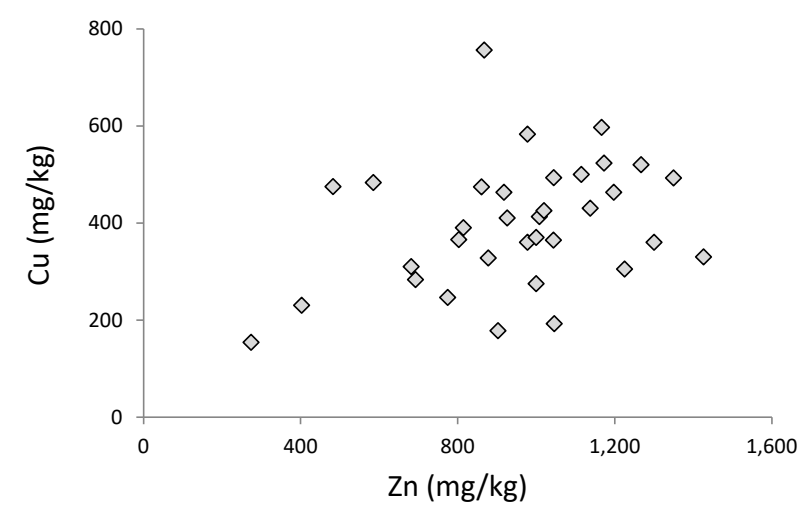

Figuur 5.4 Koper- versus zinkgehalten in zuiveringsslib zijn niet aan elkaar gecorreleerd $(n=35)$.

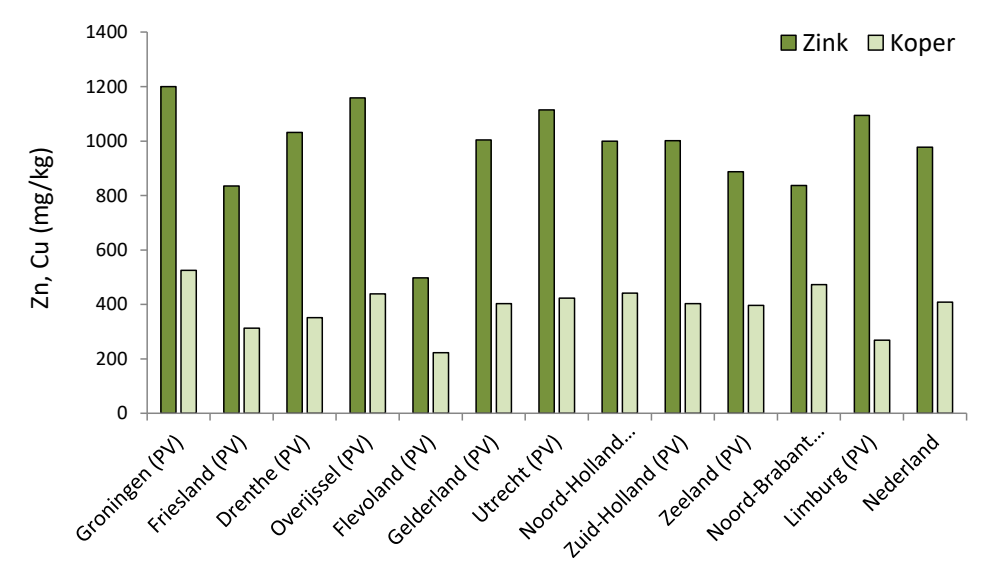

Figuur 5.5 Koper- en zinkgehalten in communaal zuiveringsslib per provincie (CBS, data 2014). 


\subsubsection{Bemestingsscenario's}

Op basis van de gemiddelde nutriëntensamenstelling van slib, mest en compost is een aantal bemestingsscenario's opgesteld (Tabel 5.3). Hierbij is gebruikgemaakt van de samenstelling van deze meststoffen zoals opgenomen in Tabel 5.2. Daarnaast zijn twee fosfaat-verarmde slibproducten toegevoegd met een 50 of $75 \%$ lager fosfaatgehalte ten opzichte van de gemiddelde samenstelling. Hierbij is aangenomen dat het gehalte aan zink met $20 \%$ daalt na extractie van fosfaat, terwijl andere zware metalen niet dalen; dit op basis van de uitkomsten van de testen met zuurextracties (zie Hoofdstuk 4). Biogranulaat is niet als apart scenario doorgerekend, omdat de belasting met zware metalen bij bemesting met biogranulaat vergelijkbaar is met de belasting bij bemesting met slib (gelijke ratio zware metalen/fosfaat).

Bij het opstellen van de bemestingsscenario's is aangenomen dat de bodem jaarlijks $60 \mathrm{~kg}$ $\mathrm{P}_{2} \mathrm{O}_{5} / \mathrm{ha} /$ jaar ontvangt. $\mathrm{Bij}$ bemesting met zuiveringsslib is de stikstofaanvoer lager dan bij bemesting met dierlijke mest. In de praktijk zal dit verschil worden aangevuld met KAS meststof. De bijdrage van KAS meststof aan de aanvoer van zware metalen is verwaarloosbaar t.o.v. die uit mest, slib of andere producten en is hier niet meegerekend. De dosering van zuiveringsslib is nu bij wet beperkt tot maximaal 2 ton droge stof per jaar op bouwland en 1 ton droge stof per jaar op grasland. Deze norm

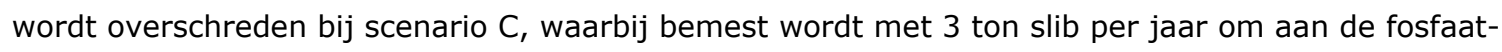
behoefte te voldoen. Daarom is scenario $D$ geïntroduceerd, waarbij bemesting met slib wordt afgewisseld met bemesting met dierlijke mest.

Tabel 5.3 Bemestingsscenario's met slib, dierlijke mest en compost die zijn gebruikt als input voor de risicomodellering ${ }^{1}$.

\begin{tabular}{|c|c|c|c|c|c|}
\hline & Scenario & Dosering & P aanvoer & N aanvoer & O.S. aanvoer \\
\hline & & (ton d.s./ha/jaar) & (kg $\left.\mathrm{P}_{2} \mathrm{O}_{5} / \mathrm{ha}\right)$ & (kg N/ha) & (kg/ha) \\
\hline A & Slib (huidig P gehalte) & 0.8 ton slib & 60 & 43 & 524 \\
\hline $\mathrm{C}$ & P-arm slib (75\% P-verlaging) & 3.0 ton slib & 60 & 172 & 2096 \\
\hline $\mathrm{D}$ & P-arm slib + mest & 1.0 ton slib +2 ton rundermest & 60 & 157 & 2218 \\
\hline $\mathrm{F}$ & Varkensmest & 1.2 ton varkensmest & 60 & 108 & 816 \\
\hline G & GFT-compost + rundermest & $\begin{array}{l}4.4 \text { ton compost }+2.6 \text { ton } \\
\text { rundermest }\end{array}$ & $60(81)^{2}$ & 135 & 3219 \\
\hline
\end{tabular}

\subsubsection{Belasting van de bodem met zware metalen}

De bemesting met slib en andere meststoffen leidt tot de aanvoer van zware metalen naar de bodem. Voor ieder scenario is de jaarlijkse vracht aan zware metalen berekend door de dosering van de meststof te vermenigvuldigen met de gehalten aan zware metalen in de meststof (Tabel 5.4). Tevens is de maximale vracht aan zware metalen berekend die bereikt zou worden onder de voorschriften van het UBM (norm maal doseringslimiet).

Ondanks het feit dat de gehalten aan koper en zink niet voldoen aan de norm volgens UBM, is bij bemesting met niet-verarmd zuiveringsslib de aanvoer van koper en zink lager dan bij bemesting met dierlijke mest of GFT-compost. De aanvoer van lood, nikkel en chroom is daarentegen hoger bij bemesting met slib dan bij bemesting met dierlijke mest, maar aanzienlijk lager dan wanneer wordt bemest met GFT-compost. GFT-compost bevat op gewichtsbasis weliswaar lagere gehalten aan zware metalen dan slib, maar door de hogere vereiste dosering om aan de P-behoefte te voldoen, is de totale aanvoer aan zware metalen hoger dan bij bemesting met slib. Bij bemesting met een fosfaatverarmd slib (scenario $\mathrm{B}, \mathrm{C}$ ) wordt een hogere dosering toegepast, waardoor de aanvoer van zware metalen evenredig toeneemt. Bij gebruik van fosfaat-verarmd slib is daarom ook de aanvoer van koper en zink hoger dan bij bemesting met dierlijke mest of compost. 
Het gebruik van (fosfaat-verarmd) zuiveringsslib leidt in alle scenario's tot een hogere aanvoer aan koper en zink dan de maximale aanvoer zoals is toegestaan onder het UBM (norm voor gehalten maal het doseringsvoorschrift). Hierbij dient dus als kanttekening opgemerkt te worden dat ook in geval van de mestscenario's sprake is van overschrijding van de aanvoer norm voor koper en zink zonder dat dit als zodanig erkend wordt, omdat deze producten niet onder deze regeling vallen. Voor de overige zware metalen ( $\mathrm{Cd}, \mathrm{Cr}, \mathrm{Hg}, \mathrm{Ni}, \mathrm{Pb}$ en As) ligt de aanvoer bij het gebruik van slib of $50 \%$ P-verarmd slib onder de maximale vracht, overeenkomend met de voorschriften in het UBM.

De aanvoer van zware metalen bij bemesting met slib en andere meststoffen kan leiden tot een toename in de gehalten aan zware metalen in de bodem indien de nettobelasting (aanvoer - afvoer) groter is dan nul. In een aantal scenario's zoals benoemd in Tabel 5.4 is inderdaad sprake van een netto-accumulatie op jaarbasis, e.e.a. afhankelijk van bodemtype, gewas en bemestingsscenario. De toename in de gehalten aan zware metalen in de bodem is modelmatig berekend voor een zand- en kleigrond en vergeleken met een referentiescenario waarin wordt bemest met dierlijke mest of compost (Tabel 5.3). Figuur 5.6 toont de berekende verandering in gehalten aan zware metalen in een zand- en kleigrond na vijftig jaar bemesting met slib, dierlijke mest en compost.

Tabel 5.4 Jaarlijkse belasting van de bodem met zware metalen voor diverse bemestingsscenario's met (fosfaat-verarmd) zuiveringsslib, dierlijke mest en compost ${ }^{1}$.

\begin{tabular}{|c|c|c|c|c|c|c|c|c|c|}
\hline & Scenario & Cd & $\mathrm{Cr}$ & Cu & $\mathrm{Hg}$ & $\mathrm{Ni}$ & $\mathrm{Pb}$ & $\mathrm{Zn}$ & As \\
\hline A & Slib (huidig P gehalte) & 0.9 & 32 & 314 & 0.5 & 21 & 82 & 753 & 1 \\
\hline $\mathrm{C}$ & P-arm slib (75\% P-verlaging) & 3.7 & 126 & 1414 & 2.2 & 68 & 327 & 2409 & 4 \\
\hline $\mathrm{D}$ & P-arm slib + mest & 1.7 & 54 & 777 & 0.9 & 31 & 116 & 1278 & 2 \\
\hline $\mathrm{F}$ & Varkensmest & 0.4 & 10 & 533 & 0.2 & 11 & 7 & 1188 & 2 \\
\hline \multirow[t]{2}{*}{ G } & GFT-compost + rundermest & 2.3 & 117 & 595 & 0.6 & 59 & 243 & 1344 & 21 \\
\hline & Norm slib UBM (norm $*$ dosering) ${ }^{2}$ & 2.5 & 150 & 150 & 1.5 & 60 & 200 & 600 & 30 \\
\hline \multicolumn{10}{|c|}{$\begin{array}{l}\text { Jaarlijkse vracht aan zware metalen berekend op basis van de gemiddelde samenstelling en dosering (Tabel 6.3; 6.4). Doseringen be } \\
\text { uitgaande dat de fosfaatgebruiksnorm wordt ingevuld met de betreffende meststof. In scenario D wordt bemest met slib en mest in e } \\
\text { verhouding } 1: 2 \text {. Voor fosfaat-verarmd slib is aangenomen dat de fosfaatextractie leidt tot een afname van het zinkgehalte met } 20 \% \\
\text { (Hoofdstuk } 4 \text { ). }\end{array}$} \\
\hline
\end{tabular}

Langdurige bemesting met zuiveringsslib leidt, evenals bemesting met dierlijke mest en compost, tot een toename in koper- en zinkgehalten in de bodem. Bij gebruik van niet-verarmd slib (scenario $A$ ) is de toename in koper en zink echter lager dan bij het gebruik van dierlijke mest. Bij gebruik van fosfaat-verarmd slib (scenario B) is de toename in koper- en zinkgehalten in de bodem hoger dan bij bemesting met rundermest, maar vergelijkbaar met de toename bij bemesting met varkensmest of GFT-compost. Bij het gebruik van sterk fosfaat-verarmd slib (scenario $C, D$ ), waarbij een dosering van 3 ton droge stof per jaar nodig is om aan de fosfaatbehoefte te voldoen, zullen koper- en zinkgehalten toenemen ten opzichte van de gangbare scenario's waarbij wordt bemest met dierlijke mest.

Voor de overige zware metalen is de berekende toename in gehalten in de bodem na vijftig jaar bemesting zeer gering of is er sprake van een afname (o.a. voor cadmium in zandgrond). De toename in gehalten aan lood worden geschat op 4 tot $19 \%$. Deze toename is vergelijkbaar met de toename bij bemesting met compost. Voor nikkel wordt een toename berekend van $<2 \%$ in kleigronden en maximaal $1-40 \%$ in zandgronden. In absolute gehalten bedraagt de verandering in zandgrond maximaal $0,5 \mathrm{mg} / \mathrm{kg}$ en is daarmee zeer laag. Gehalten aan chroom en arseen blijven nagenoeg gelijk ( $<6 \%$ toename). Gehalten aan cadmium zullen in zandgronden licht afnemen, behalve bij de hoogste slibdosering (scenario C). Deze afname is het gevolg van uitspoeling die in deze gronden hoger is dan de aanvoer via bemesting. In kleigronden wordt een lichte stijging in cadmiumgehalten berekend (2-10\%). Wanneer de dosering van slib wordt beperkt tot maximaal 1,5 ton per hectare (scenario $A, B$ ) bedraagt de toename in de gehalten van zware metalen (m.u.v. koper en zink) in de bodem maximaal 
$10 \%$ ten opzichte van de huidige gehalten in zand- en kleigronden. Tot slot kan m.b.t koper en zink geconcludeerd worden dat gebruik van slib als meststof weliswaar leidt tot een toename aan de gehalten in de bodem van beide metalen, maar dat deze toename niet groter is dan die verwacht wordt bij voortgaand gebruik van dierlijke mest als belangrijkste meststof.

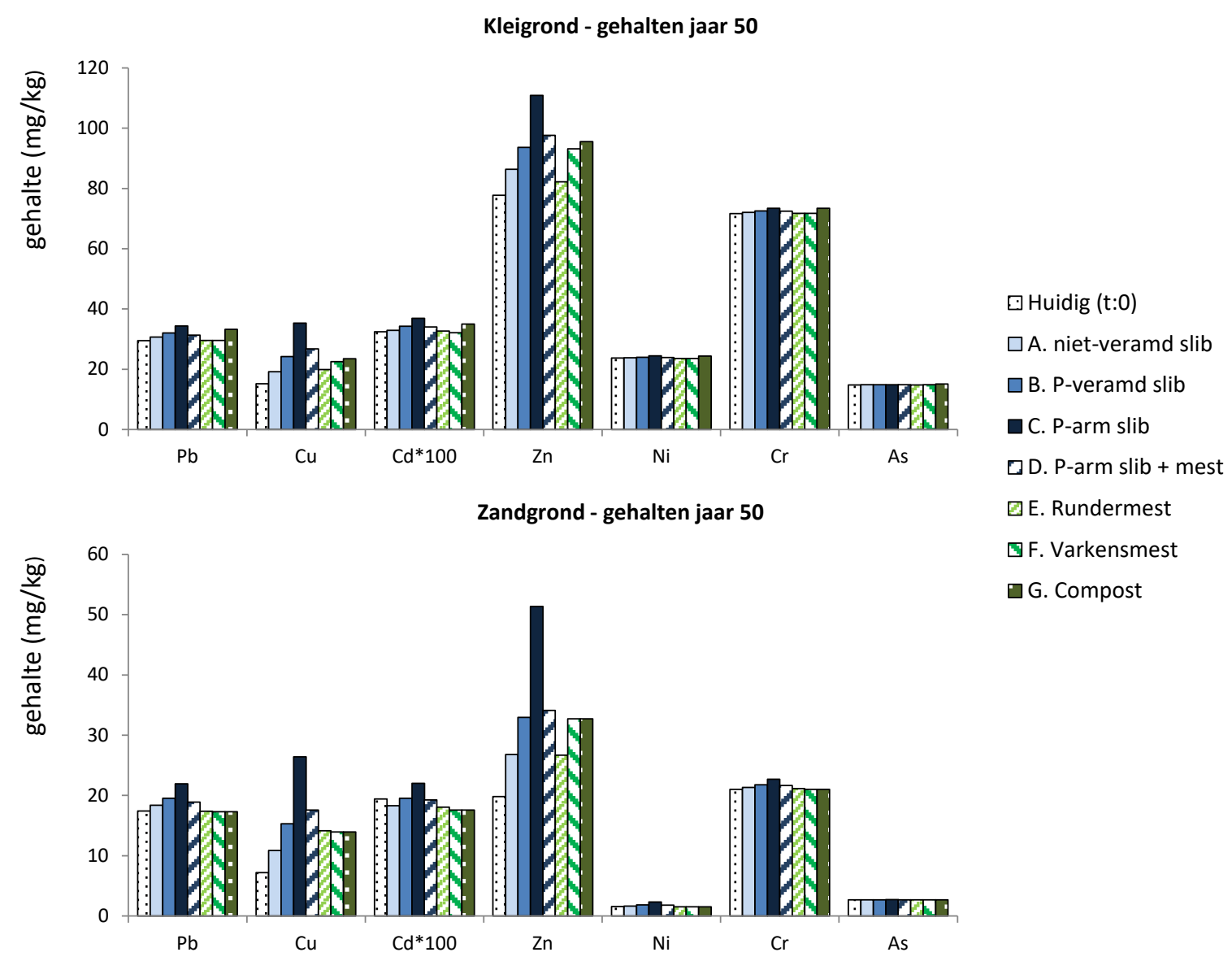

Figuur 5.6 Berekende gehalten aan zware metalen in kleigrond en zandgrond na 50 jaar bemesting met (fosfaat-verarmd) zuiveringsslib, dierlijke mest of GFT compost volgens scenario's beschreven in Tabel 5.3.

\subsubsection{Risico's van zware metalen voor de landbouw}

Bemesting met zuiveringsslib leidt op een termijn van vijftig jaar tot een toename van koper- en zinkgehalten in landbouwbodems (Figuur 5.6). In deze paragraaf wordt besproken of deze toename kan leiden tot het overschrijden van bodemnormen en tot verhoging van koper- en zinkgehalten in gewassen. Deze analyse beperkt zich tot de metalen koper en zink, omdat de berekende toename in gehalten voor andere zware metalen na vijftig jaar bemesting met slib verwaarloosbaar klein is.

Voor landbouwgronden zijn de zogenaamde LAC2006-waarden (Römkens et al. 2007) van toepassing (Tabel 5.5). Deze waarden zijn advieswaarden en geen bindende normen. De LAC2006-waarden liggen op een niveau waarboven een kans bestaat dat ofwel de kwaliteit van producten niet aan de warenwet voldoet ofwel dat er een kans is op het voorkomen van ziekten voor landbouwhuisdieren. De LAC2006-waarden variëren voor landgebruiksvorm en bodemtype. Voor zowel koper als zink geldt dat er geen kwaliteitsnormen zijn voor humane voeding. Alleen voor gras (veevoer) bestaan ruwvoedernormen ( $15 \mathrm{mg} / \mathrm{kg}$ voor schapen op basis van $12 \%$ vocht). Voor zink variëren de LAC2006waarden van $150 \mathrm{mg} / \mathrm{kg}$ voor zandgrond (geen onderscheid naar functie) en van $350 \mathrm{mg} / \mathrm{kg}$ tot $660 \mathrm{mg} / \mathrm{kg}$ voor kleigrond (afhankelijk van bodemfunctie). De berekende gehalten voor zink in de bodem na vijftig jaar continue bemesting met slib liggen ruimschoots beneden deze LAC2006waarden. Dit geldt ook voor scenario $C$ warin een hoge slibdosering van 3 ton droge stof per hectare 
wordt gehanteerd (sterk fosfaat-verarmd slib). Voor koper is de striktste LAC2006-waarde van toepassing voor grasland dat wordt beweid door schapen $(30 \mathrm{mg} / \mathrm{kg}$ ) vanwege de hoge gevoeligheid van schapen voor koper. Feitelijk is deze LAC-waarde alleen van toepassing voor Texelaars. Voor alle andere vormen van landgebruik bedraagt de LAC-waarde $50 \mathrm{mg} / \mathrm{kg}$ voor zandgrond en 80 tot $200 \mathrm{mg} / \mathrm{kg}$ voor kleigrond. Bij de hoogste slibdosering (scenario C) wordt de striktste LAC2006waarde voor koper, uitsluitend van toepassing bij begrazing door schapen, na vijftig jaar net benaderd. $\mathrm{Er}$ is daarmee een geringe kans op effecten. Bij de lagere doseringen van slib (scenario's A en B) blijven de berekende kopergehalten in zowel zand- als kleigronden ruim beneden de LACwaarden, waardoor geen negatieve effecten voor landbouw zullen ontstaan. In algemene zin kan dus geconcludeerd worden dat de hier gepresenteerde scenario's met betrekking tot koper en zink niet leiden tot risico's voor de landbouw.

Tabel 5.5 Berekende gehalten aan koper en zink in landbouwgrond na 50 jaar bemesting met zuiveringsslib, dierlijke mest of compost en LAC2006-waarden voor landbouwgrond.

\begin{tabular}{|c|c|c|c|c|c|}
\hline & \multirow[b]{2}{*}{ Scenario } & \multicolumn{2}{|c|}{ Zandgrond } & \multicolumn{2}{|c|}{ Kleigrond } \\
\hline & & $\begin{array}{c}\text { Cu_bodem } \\
(\mathrm{mg} / \mathrm{kg})\end{array}$ & $\begin{array}{c}\text { Zn_bodem } \\
\text { (mg/kg) }\end{array}$ & $\begin{array}{c}\text { Cu_bodem } \\
\text { (mg/kg) }\end{array}$ & $\begin{array}{c}\text { Zn_bodem } \\
\text { (mg/kg) }\end{array}$ \\
\hline $\mathrm{A}$ & Slib (huidig P gehalte) & 11 & 27 & 19 & 86 \\
\hline $\mathrm{B}$ & P-verarmd slib (50\% P-verlaging) & 15 & 33 & 24 & 93 \\
\hline $\mathrm{D}$ & P-arm slib + mest & 17 & 34 & 27 & 98 \\
\hline $\mathrm{E}$ & Rundveemest & 14 & 27 & 23 & 86 \\
\hline $\mathrm{F}$ & Varkensmest & 14 & 33 & 22 & 93 \\
\hline G & GFT-compost + mest & 15 & 35 & 23 & 95 \\
\hline
\end{tabular}

\subsubsection{Risico's voor uitspoeling van zware metalen}

Voor de eerder beschreven bemestingsscenario's is doorgerekend wat het effect is op de uitspoeling van koper en zink uit landbouwgronden na vijftig jaar bemesting. Deze modeluitkomsten zijn weergegeven in Figuur 5.7, uitgedrukt als de concentraties van koper en zink in het poriewater van zand- en kleigrond. De verschillen in de uitspoeling tussen zand- en kleigronden zijn aanzienlijk. Dit is voor een groot deel te wijten aan de verschillen in bodemeigenschappen die leiden tot een lagere bindingscapaciteit voor zware metalen in zandgronden dan in kleigronden. Onder meer de gemiddeld lagere gehalten aan organische stof en klei in combinatie met de lagere $\mathrm{pH}$ in zandgronden leiden tot hogere zink- en koperconcentraties in het poriewater in zandgrond dan in kleigrond. Dit ondanks de lagere totaalgehalten in zandgronden.

Het gebruik van zuiveringsslib als meststof leidt, evenals het gebruik van dierlijke mest en compost, tot een toename in de uitspoeling van koper en zink uit landbouwgronden. Op kleigronden is deze toename relatief klein, op zandgronden kan de toename substantieel zijn. Na vijftig jaar gebruik van niet-verarmd zuiveringsslib (scenario A) is de koperuitspoeling lager en de zinkuitspoeling vergelijkbaar met de uitspoeling bij het gebruik van runderdrijfmest. Bij het gebruik van zuiveringsslib met een $50 \%$ verlaagd fosfaatgehalte (scenario B) is de uitspoeling van koper en zink verhoogd ten opzichte van rundermest en vergelijkbaar met het scenario waarin wordt bemest met varkensmest of GFT-compost. Het gebruik van sterk fosfaat-verarmd slib (scenario C, D) leidt tot een sterke toename in de uitspoeling ten opzichte van de referentiescenario's. Dit komt omdat er bij een lager fosfaatgehalte een hogere dosering nodig is om de fosfaatbehoefte te vullen. 
Op kleigronden zijn concentraties aan koper en zink in het uitspoelende water laag en worden geen risico's verwacht m.b.t. van overschrijding van waterkwaliteitsnormen. Op zandgronden met een hoge grondwaterstand kan de belasting van landbouwgronden met zware metalen, hetzij uit mest of slib, substantieel bijdragen aan de belasting van het oppervlaktewater (Bonten et al. 2010). De standaard PNEC (predicted no-effect concentration) voor koper en zink in oppervlaktewater bedraagt respectievelijk 14.2 en $34 \mu \mathrm{g} / \mathrm{l}$ (EC, 2008a,b). Wanneer de berekende totaalconcentraties vergeleken worden met de PNEC, dan blijkt dat bij de hoogste slibdosering (scenario C) de PNEC-waarde voor koper na vijftig jaar wordt overschreden. Bij de lagere doseringen blijft de koperconcentratie in het uitspoelende water (net) onder de PNEC-waarde. Voor zink wordt de PNEC-waarde in het uitspoelende water uit zandgrond eveneens overschreden na vijftig jaar bemesting met slib, mest of compost.

Echter, deze PNEC-waarden zijn gebaseerd op totaalconcentraties, terwijl bekend is dat milieurisico's beter ingeschat kunnen worden op basis van de biobeschikbare concentratie. Hiertoe is het binnen de KRW-beoordeling toegestaan om koper en zink te toetsen via de zogenaamde tweedelijnsbeoordeling waarbij een locatiespecifieke norm wordt berekend op basis van de $\mathrm{pH}$ en de DOC-concentratie. Binnen de uitgevoerde modelstudie is een dergelijke correctie voor pH en DOC niet uitgevoerd. Wel is vanuit literatuur bekend dat het aantal overschrijdingen van koper en zink in oppervlaktewateren sterk afneemt na uitvoering van een tweedelijnsbeoordeling (Snijders, 2011).
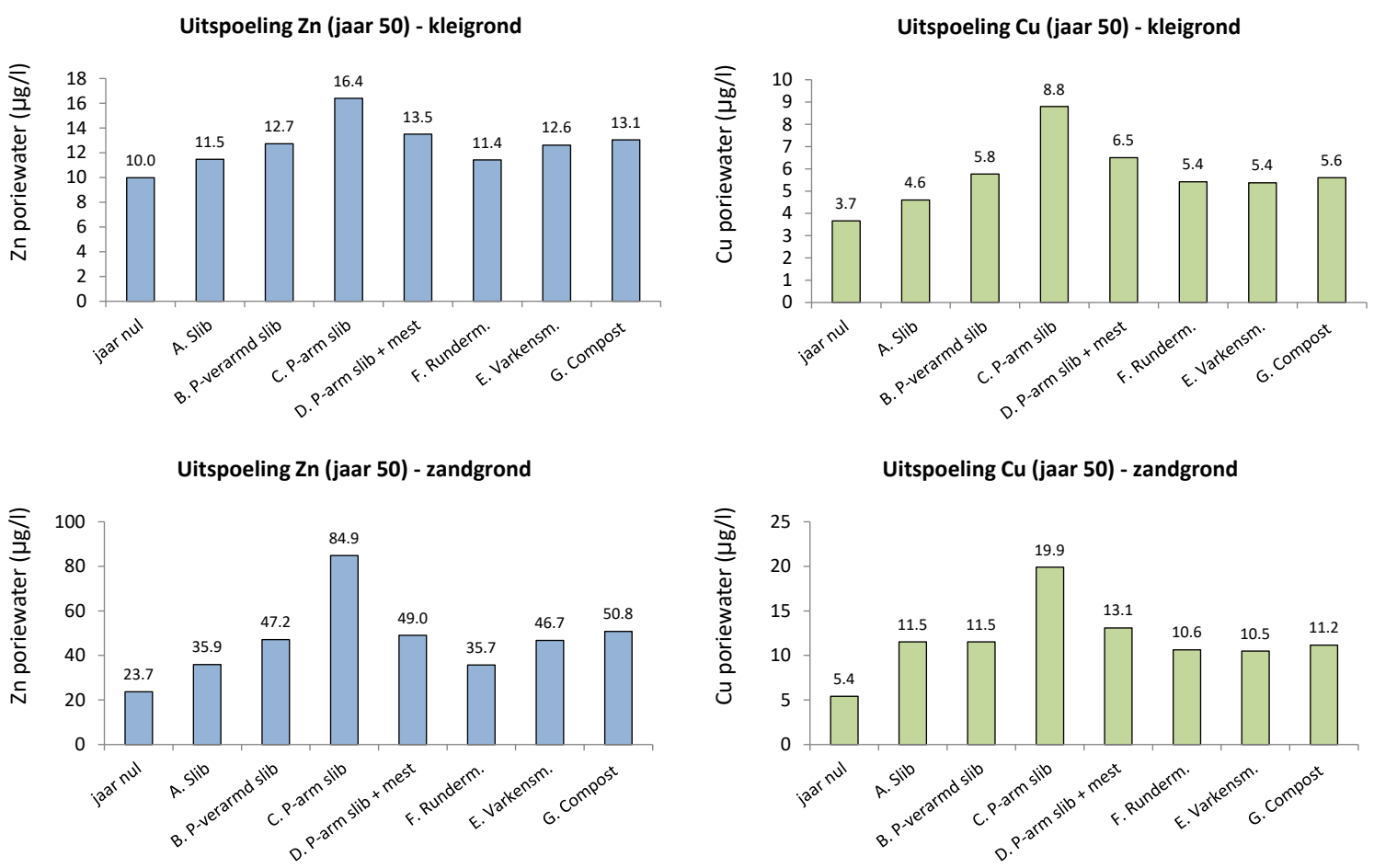

Figuur 5.7 Zink- en koperconcentraties in het bodemvocht van kleigrond (boven) en zandgrond (onder) na 50 jaar bemesting met slib of dierlijke mest (scenario's zie Tabel 5.3).

De uitkomsten van de milieurisicobeoordeling voor de belasting van landbouwgronden met zware metalen zijn samengevat in Tabel 5.6. 
Tabel 5.6 Samenvatting van de milieurisicobeoordeling in relatie tot de belasting van zware metalen bij het gebruik van zuiveringsslib als meststof ${ }^{1}$.

\begin{tabular}{|c|c|c|c|c|}
\hline & Slibproduct & $\begin{array}{c}\text { P gehalte } \\
\text { (kg } \mathrm{P}_{2} \mathrm{O}_{5} / \text { ton) }\end{array}$ & $\begin{array}{c}\text { Dosering } \\
\text { (ton/ha/jaar) }\end{array}$ & Milieurisicobeoordeling zware metalen ( 50 jaar) \\
\hline A & $\begin{array}{l}\text { Niet-verarmd } \\
\text { slib }\end{array}$ & 78 & 0.7 ton & $\begin{array}{l}\text { - Koper en zink belasting van de bodem en uitspoeling naar } \\
\text { grondwater lager dan bij gebruik van dierlijke mest. } \\
\text { - Accumulatie van overige zware metalen verwaarloosbaar klein. } \\
\text { - Geen negatieve effecten voor landbouw of voedselveiligheid. }\end{array}$ \\
\hline $\mathrm{C}$ & Fosfaatarm slib & 19 & 3 ton & $\begin{array}{l}\text { - Toename in de koper- en zinkbelasting en uitspoeling ten } \\
\text { opzichte van gebruik van dierlijke mest of compost. } \\
\text { - Accumulatie van overige zware metalen verwaarloosbaar klein. } \\
\text { - Geen negatieve effecten voor landbouw of voedselveiligheid. }\end{array}$ \\
\hline
\end{tabular}

1 Dosering in ton droge stof per jaar. Milieurisicoanalyses is beperkt tot de effecten van zware metalen.

\subsubsection{Reactiviteit van zware metalen in slib en slibproducten}

In deze paragraaf wordt ingegaan op de mate waarin metalen in slib reactief (ook wel potentieel) beschikbaar zijn. De reactiviteit of potentiële beschikbaarheid van zware metalen wordt gemeten met een extractie met verdund salpeterzuur $\left(0.43 \mathrm{M} \mathrm{HNO}_{3}\right)$ en uitgedrukt als percentage ten opzichte van het totaalgehalte van het betreffende metaal. Met potentieel beschikbaar of reactief wordt die fractie aan zware metalen bedoeld die in de bodem beschikbaar is of in de toekomst beschikbaar komt en dus bijdraagt aan uitspoeling en plant-opname. Daarentegen zal de niet-reactieve fractie (d.w.z. het verschil tussen het totaalgehalte en de reactieve fractie) niet bijdragen aan uitspoeling of plantopname. De extractie met verdund $\mathrm{HNO}_{3}$ wordt momenteel beschouwd als de effectiefste methode voor de uitvoering van risicobeoordelingen van metalen in de bodem (Lijzen et al. 2016), juist omdat deze corrigeert voor het niet-reactieve deel van metalen en alleen die fractie van de aanwezige metalen extraheert die het risico bepalen. Deze methode is effectief gebleken bij zowel het voorspellen van de beschikbaarheid van metalen in het poriewater (Groenenberg et al. 2017) en is ook een goede maat voor de opneembaarheid van metalen door de mens (Rodrigues et al. 2013).

In Tabel 5.7 staat een overzicht van de reactiviteit van zware metalen zoals bepaald in zuiveringsslib van zes RWZI's. Figuur 5.9 toont de gemiddelde reactiviteit van zware metalen in slib, vergist slib, biogranulaat en hydrochar. Een vergelijking met de reactiviteit van zware metalen in compost of dierlijke mest is niet uitgevoerd, omdat hiervan vooralsnog geen gegevens beschikbaar zijn.

Tabel 5.7 Reactiviteit van zware metalen (als procent van totaalgehalten) in zuiveringsslib ${ }^{1}$.

\begin{tabular}{|c|c|c|c|c|c|c|c|c|}
\hline RWZI & Vergist & $\begin{array}{c}\mathrm{Cr} \\
\% \text { tot. }\end{array}$ & $\begin{array}{c}\mathrm{Cu} \\
\% \text { tot. }\end{array}$ & $\begin{array}{c}\text { Ni } \\
\% \text { tot. }\end{array}$ & $\begin{array}{c}\text { Zn } \\
\% \text { tot. }\end{array}$ & $\begin{array}{c}\text { As } \\
\% \text { tot. }\end{array}$ & $\begin{array}{c}\text { Cd } \\
\% \text { tot. }\end{array}$ & $\begin{array}{c}\mathrm{Pb} \\
\% \text { tot. }\end{array}$ \\
\hline Den Bosch & Nee & 0.39 & 0.75 & 0.48 & 0.85 & 0.67 & 0.75 & 0.81 \\
\hline Etten & $\mathrm{Ja}$ & 0.41 & 0.22 & 0.46 & 0.60 & 0.41 & 0.50 & 0.48 \\
\hline Olburgen & $\mathrm{Ja}$ & 0.22 & 0.38 & 0.33 & 0.65 & 0.44 & 0.57 & 0.46 \\
\hline Nieuwgraaf & $\mathrm{Ja}$ & 0.27 & 0.17 & 0.37 & 0.57 & 0.34 & 0.53 & 0.64 \\
\hline Gemiddeld & & 0.34 & 0.40 & 0.44 & 0.68 & 0.49 & 0.61 & 0.61 \\
\hline Std. Dev. & & 0.10 & 0.26 & 0.08 & 0.13 & 0.14 & 0.13 & 0.15 \\
\hline
\end{tabular}

1 Beschikbare gehalten bepaald na extractie met $0.43 \mathrm{M} \mathrm{HNO}_{3}$. Totaalgehalten bepaald na destructie met Aqua Regia. 
De data in Tabel 5.7 laten zien dat de reactiviteit varieert van $34 \%$ voor chroom tot $68 \%$ voor zink. Ruwweg de helft van de in het slib aanwezige metalen kan daarmee als potentieel beschikbaar geclassificeerd worden. Daarbij valt wel op dat de variatie in het percentage reactieve metalen voor sommige elementen (met name koper, lood, chroom en arseen) groot is wanneer het slib van verschillende RWZI's met elkaar vergeleken worden. Voor cadmium, nikkel en zink zijn de verschillen iets minder uitgesproken.

Een deel van de variatie in reactiviteit van zware metalen tussen RWZI's is terug te voeren op het verschil tussen vergist en niet-vergist slib (zie ook Figuur 5.8). Voor alle metalen, en met name voor koper, geldt daarbij dat de reactiviteit afneemt na vergisting. Dit duidt op een stabilisatie van organische stof waarbij de gevormde organische componenten met de daarin opgenomen metalen zodanig stabiel zijn dat ze onder de condities van de extractie met HNO3 de metalen nog steeds vasthouden. Uiteraard zijn er andere factoren die de verschillen tussen de RWZI's ook verklaren, maar de aantallen monsters in deze set zijn te klein om daar uitspraken over te kunnen doen. De twee belangrijkste factoren die daarbij genoemd moeten worden, zijn de herkomst van het slib, d.w.z. de mogelijke aanwezigheid van specifieke bronnen van metalen in het slib en de chemische vorm ervan, en de samenstelling van het slib zelf, waarbij vooral de metaalbindende componenten van belang zijn. Zo zijn zware metalen voor een groot deel gebonden aan organische stof (o.a. cadmium en koper), kleimineralen (o.a. nikkel en zink) en ijzer- en of aluminium (hydr)oxiden (o.a. arseen, lood en nikkel).

Doordat de verwerking van slib door middel van vergisten, composteren of HTC leidt tot een verandering in de samenstelling van organische stof, is het interessant om te kijken of de reactiviteit van metalen dienovereenkomstig verandert. Figuur 5.8 toont de gemiddelde reactiviteit van zware metalen in slib, vergist slib, biogranulaat en hydrochar. De data tonen aan dat voor koper, nikkel, en in mindere mate zink en cadmium, de reactiviteit afneemt in de volgorde: slib > vergist slib > biogranulaat (niet voor cadmium en zink) > biochar. Voor arseen en chroom, die beide voor een relatief groot deel binden aan oxiden in plaats van aan organische stof, zien we deze trend niet en neemt de (relatieve) reactiviteit in de verschillende producten niet of niet significant af t.o.v. die in slib.

Vooral voor koper wordt een zeer sterke afname van de reactiviteit gemeten na slibverwerking. In biogranulaat en biochar is koper voor meer dan $80 \%$ aanwezig in een niet-reactieve vorm. Dit is wellicht het gevolg van de omzetting van organische stof in zeer resistente componenten waarbinnen een groot deel van het aanwezige koper, en ook nikkel en cadmium, zodanig gebonden zit dat dit niet meer vrijkomt bij de extractie met verdund $\mathrm{HNO}_{3}$. Voor zink en ook cadmium geldt daarbij dat het verschil tussen granulaat en biochar groot is, waarbij vooral de reactiviteit in biochar duidelijk afneemt t.o.v. het uitgangsmateriaal en t.o.v. biogranulaat. Blijkbaar zijn de veranderingen in de structuur van organische stof in geval van biochar zodanig dat dit leidt tot een hoge mate van stabilisatie van de meeste metalen.

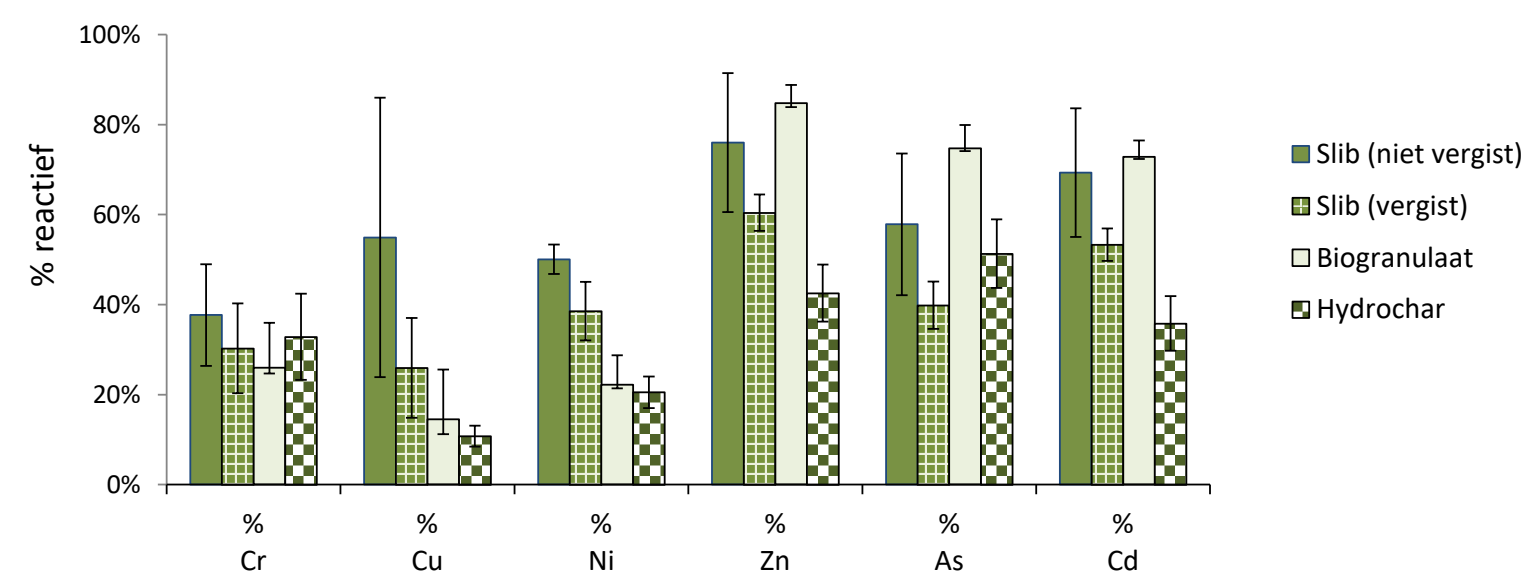

Figuur 5.8 Percentage zware metalen extraheerbaar in $0.43 \mathrm{~N} \mathrm{HNO}_{3}$, bepaald voor niet-vergist slib ( $n: 3)$, vergist slib (n:3), biogranulaat (n:2) en hydrochar ( $n: 6)$. Gemiddelde percentages en standaardafwijking. 
Slibverwerking leidt zoals getoond in Figuur 5.8 in veel gevallen tot een afname van de reactiviteit van zware metalen. Slibverwerking leidt echter ook tot een toename in de totaalgehalten aan zware metalen als gevolg van een afname van de hoeveelheid organische stof in het slibproduct. Deze toename heeft echter geen consequenties voor de totale aanvoer van zware metalen naar landbouwgronden, omdat de dosering van slibproducten in Nederland wordt afgestemd op het fosfaatgehalte. En omdat het gehalte aan zware metalen ten opzichte van het fosfaatgehalte in het slib niet verandert door slibverwerking, neemt de vracht aan metalen bij aanwending van een bepaalde hoeveelheid fosfaat niet toe. Dit betekent daardoor ook dat composteren en hydrothermale slibverwerking een netto positief effect hebben op de milieukundige kwaliteit van het slibproduct, omdat is aangetoond dat de reactiviteit van zware metalen afneemt en deze dus een lager risico vormen in de bodem en minder beschikbaar zijn voor uitspoeling.

Samengevat: door composteren en hydrothermale slibbehandeling kan de reactiviteit van koper, zink en nikkel met 50 tot $80 \%$ verlaagd kan worden ten opzichte van de reactiviteit in niet-verwerkt slib. In de huidige beoordelingssystematiek (op basis van totaalgehalten) vormen deze drie zware metalen vaak een knelpunt. Wanneer toekomstige normen voor de bodem gebaseerd worden op een risicobeoordeling op basis van de $\mathrm{HNO}_{3}$-extractie, kan dit leiden tot een verruiming van de afzetmogelijkheden naar de landbouw voor biogranulaat en in hogere mate voor hydrochar.

\subsubsection{Microbiologische kwaliteit}

Zuiveringsslib kan diverse pathogenen bevatten, waaronder virussen, bacteriën, protozoa en helminths. Naast voor de mens schadelijke pathogenen kan zuiveringsslib eveneens voor de landbouw schadelijke parasieten bevatten. In EU-lidstaten waar het gebruik van slib in de landbouw gangbaar is, wordt anaerobe vergisting in de regel gezien als minimale sanitatiestap voor toepassing van de slib in de landbouw. Uit een overzicht van toegepaste sanitatiemethoden voor slib in EU-lidstaten blijkt dat er echter ook veelal gebruik wordt gemaakt van aanvullende sanitatiemethoden, waaronder composteren, pasteuriseren of chemische stabilisatie. Het UBM stelt geen normen voor maximaal toelaatbare concentraties aan pathogenen in zuiveringsslib. In de EU-Meststoffenverordening zijn wel normen opgenomen voor E.coli of Enterococcaceae en Salmonella in organische meststoffen en bodemverbeteraars (paragraaf 2.4). Wanneer deze normen vergeleken worden met in literatuur gerapporteerde gehalten van E.coli in uitgegist slib van Nederlandse RWZI's (Tabel 5.8), dan blijkt dat uitgegist slib niet aan deze normen kan voldoen. Dit suggereert dat aanvullende behandelingen en/of andere verwerking nodig zijn. Zo is bekend dat afdoding van pathogenen toeneemt bij hogere temperatuur. Thermofiele vergisting $\left(50-60^{\circ} \mathrm{C}\right.$ ) is zeer effectief in het afdoden van E.coli en Enterococci, maar heeft slechts beperkt effect op de mate van voorkomen van de bacteria Clostridiae spp (Salhström et al. 2004). Composteren, mits hoge temperaturen worden bereikt, wordt beschouwd als effectieve sanitatiemethode. Pasteuriseren, waarbij slib gedurende 30 minuten wordt verhit tot temperaturen boven $70^{\circ} \mathrm{C}$, biedt eveneens een effectieve vorm van sanitatie. Pasteurisatie wordt nu al veel toegepast om de dikke fractie van dierlijke mest te hygiëniseren en exportwaardig te maken. Chemische stabilisatie met ongebluste kalk (calciumoxide) kan eveneens perspectief bieden. Dosering van calciumoxide en de daaruit volgende toename in $\mathrm{pH}$ resulteert in effectieve afdoding van salmonella, streptococci en Clostridium. Op basis van literatuur blijkt een dosering van $2 \%$ calciumoxide voldoende te zijn om de $\mathrm{pH}$ te verhogen naar $\mathrm{pH} 12.5$ en om slib voldoende te hygiëniseren (Andreadakis, 2000). De kosten voor calciumoxide kunnen naar verwachting deels worden terugverdiend door een hogere afzetwaarde van een product met een hoge zuur-neutraliserende waarde.

Tabel 5.8 Pathogenen in uitgegist slib van drie locaties ${ }^{1}$.

\begin{tabular}{|c|c|c|c|c|}
\hline & E.coli & Cryptosporidium & F-specifieke fagen & $\begin{array}{l}\text { Norm E.coli EU- } \\
\text { meststofffen }^{2}\end{array}$ \\
\hline & (kve/ml) & (kve/ml) & (kve/ml) & (kve/gr) \\
\hline Amsterdam West & 34.000 & 110.000 & 335 & $<1000$ \\
\hline Leuven & 3.400 & 120.000 & $<5$ & $<1000$ \\
\hline
\end{tabular}




\subsection{Conclusies}

- Landbouwkundig gebruik van zuiveringsslib is in Nederland toegestaan. Echter, zuiveringsslib voldoet niet aan de normen voor koper en zink. Nikkel, kwik en cadmium vormen in mindere mate een knelpunt.

- Gebruik van zuiveringsslib als meststof leidt, evenals het gebruik van dierlijke mest of GFTcompost, tot accumulatie van koper en zink in landbouwgronden. De mate van accumulatie bij gebruik van slib en P-verarmd slib (50\%) ligt echter in dezelfde orde van grootte als die bij gebruik van dierlijke mest. Alleen in geval van $75 \%$ P-verarmd slib is de accumulatie verhoogd t.o.v. die bij gebruik van mest. Voor de overige zware metalen is de mate van accumulatie verwaarloosbaar.

- Bij geen van de hier uitgewerkte scenario's leidt de accumulatie van koper en zink tot overschrijding van landbouwkundige advieswaarden voor de bodem (LAC-waarden) of tot risico's voor de gewaskwaliteit.

- De uitspoeling van koper en zink naar het grondwater is bij gebruik van slib niet afwijkend van die bij gebruik van dierlijke mest. In beide gevallen is er wel sprake van een toename in de komende decennia, omdat zowel bij gebruik van slib als mest de gehalten in de bodem toenemen.

- Milieukundige consequenties op langere termijn t.a.v. koper en zink bij aanwending van slib zijn niet anders dan die wanneer dierlijke mest wordt aangewend als bron voor fosfaat in de landbouw.

- Vergisten en composteren van slib leiden tot een sterke verlaging van de reactiviteit van koper en nikkel. Hydrothermale carbonisatie leidt tot een sterke verlaging van de beschikbaarheid van koper, nikkel en zink. Indien beschikbaarheid wordt meegenomen in toekomstige normgeving, kan dit leiden tot een verruiming van de afzetmogelijkheden voor gecomposteerd slib en, in grotere mate, voor hydrochar. 


\section{$6 \quad$ Synthese en perspectieven}

\subsection{Synthese}

\subsubsection{Aanleiding}

Nederlandse waterschappen produceren gezamenlijk 1,3 miljoen ton communaal zuiveringsslib. Zuiveringsslib vormt een bron van potentieel waardevolle nutriënten en organische stof, die grotendeels verloren gaan met huidige thermische verwerkingsroutes. Waterschappen hebben de ambitie uitsproken om alternatieve afzetroutes te ontsluiten waarbij energiewinning (energiefabriek) en hergebruik van waardevolle componenten (grondstoffenfabriek) een centrale plaats innemen. Toepassing van (verwerkt) slib in de landbouw wordt gezien als een mogelijkheid om nutriënten uit slib nuttig te hergebruiken en gelijktijdig de verwerkingskosten voor zuiveringsslib te verlagen. In dit project is beoordeeld of er perspectieven zijn om slib of slibproducten in de toekomst in de landbouw te gebruiken. Hiervoor is gekeken naar ontwikkelingen in regelgeving rondom gebruik van meststoffen en slib, de landbouwkundige waarde van slib, afzetmogelijkheden in de landbouw en de milieukundige risico's van zware metalen bij het gebruik van slib als meststof.

\subsubsection{Toekomstperspectieven in relatie tot beleidsontwikkelingen}

Zowel op Europees als op nationaal niveau vinden, in het kader van de transitie naar de circulaire economie, diverse ontwikkelingen plaats om het hergebruik van nutriënten te stimuleren. Door invoering van een nieuwe EU-Meststoffenverordening tracht de Europese Commissie om de vrije handel in meststoffen met voorheen een afvalstatus te stimuleren. Zuiveringsslib en producten uit slib zijn hierbij echter expliciet uitgesloten. Wel loopt er op dit moment een JRC-onderzoek naar de mogelijkheden om struviet, biochar en verbrandingsassen uit o.a. zuiveringsslib toch toe te laten als meststof. Of, en zo ja onder welke voorwaarden, deze producten uit slib toegelaten kunnen worden tot het vrije handelsverkeer in de EU zal pas in 2018 duidelijk worden. Verder heeft de Europese Commissie de ambitie om de afhankelijkheid van externe fosfaatbronnen terug te dringen. Terugwinning van fosfaat uit communaal afvalwater speelt een belangrijke rol bij het realiseren van deze ambities, maar een verplichting tot fosfaatterugwinning uit communaal afvalwater is vooralsnog niet voorzien. Een aantal EU-lidstaten (Zwitserland, Duitsland) heeft fosfaatterugwinning uit communaal afvalwater verplicht gesteld.

\subsubsection{Landbouwkundige waarde zuiveringsslib}

Zuiveringsslib moet zich op basis van de samenstelling primair positioneren als organische meststof, i.e. een bron van nutriënten. Zuiveringsslib bevat veel fosfaat. Het fosfaatgehalte in slib is viermaal hoger dan in rundermest en tienmaal hoger dan in compost. Ondanks dat fosfaat een waardevol en schaars nutriënt is, wordt dierlijke mest in Nederland met geld toe afgezet omdat de fosfaatproductie de fosfaatgebruiksruimte overschrijdt. Zuiveringsslib zal dus moeten concurreren met de afzet van dierlijke mest. Door het fosfaatgehalte van zuiveringsslib te verlagen, neemt de mate van verdringing van dierlijke mest af en sluit de nutriëntensamenstelling beter aan bij de vraag vanuit de akkerbouw. Om aan te sluiten bij de vraag van de markt wordt aanbevolen om het fosfaatgehalte van slib met circa $75 \%$ te verlagen. De samenstelling van het resulterende fosfaatverarmde slibproduct komt dan overeen met runderdrijfmest wat, tegen betaling, goed te plaatsen is in de akkerbouw. Op basis van labtesten is het verlagen van het fosfaatgehalte met $50-75 \%$ haalbaar, mits gebruik wordt gemaakt van ijzerarm slib. Om zuiveringsslib te kunnen positioneren als een organische bodemverbeteraar (i.e. vervanger van compost) moet het fosfaatgehalte met meer dan $85 \%$ verlaagd moeten worden én moet het product, evenals compost, in aanmerking komen voor een fosfaatvrije voet. Dit scenario moet echter als niet haalbaar worden beoordeeld, omdat een dergelijke verlaging van het fosfaatgehalte praktisch gezien niet haalbaar is en omdat de belasting van landbouwgronden met zware metalen aanzienlijk toeneemt wanneer wordt bemest met sterk fosfaatverarmde producten. 
Buiten Nederland is er wel vraag naar fosfaatrijke organische meststoffen. Export van slibproducten naar Frankrijk, waar het gebruik van gecomposteerd slib in de landbouw gangbaar is, vormt zodoende een mogelijkheid tot landbouwkundig gebruik van slib. Bij deze afzetroute hoeft het fosfaatgehalte niet verlaagd te worden. Uiteraard dient het product wel conform de criteria van het ontvangende land te voldoen aan eisen t.a.v. de microbiologische kwaliteit, traceerbaarheid etc. GMB BioEnergie is voornemens om hun biogranulaat via deze route terug te brengen naar de landbouw. Wel moet hierbij de kanttekening worden geplaatst dat biogranulaat een afvalstatus heeft, waardoor export voor zowel het importerende als exporterende land gepaard gaat met grote juridische en administratieve lasten.

\subsubsection{Fosfaatverwijdering en terugwinning}

Door zuiveringsslib te scheiden in een minerale fosfaatmeststof en een fosfaat-verarmde organische meststof sluit de nutriëntensamenstelling van het slib beter aan bij de vraag vanuit de Nederlandse landbouw. Daarbij is zuiveringsslib in potentie een relevante grondstof voor de terugwinning van fosfaat dat op termijn schaars zal worden. In deze studie is beoordeeld of vergaande fosfaatterugwinning uit zuiveringsslib met behulp van een zuur- en baseprocedé perspectief biedt. Hierbij wordt zuiveringsslib aangezuurd waardoor fosfaat in oplossing gaat. Vervolgens wordt het slib ontwaterd waarna fosfaat wordt teruggewonnen uit het afgescheiden rejectiewater door het doseren van calciumhydroxide. Op basis van laboratoriumtesten blijkt dat 72-82\% van het fosfaat in oplossing gaat wanneer slib met zwavelzuur wordt aangezuurd tot $\mathrm{pH} 3$. Omdat een deel van het opgeloste fosfaat na ontwatering achterblijft in de slibkoek, wordt geschat dat 60-65\% van het fosfaat met deze methode teruggewonnen kan worden. Een voorwaarde is wel dat het slib een laag ijzergehalte bevat (Fe/P ratio $<0.4)$. Naar verwachting kan grofweg de helft van de RWZI's in Nederland voldoen aan deze voorwaarde, omdat zij geen gebruikmaken van metaalzouten voor defosfatering. Omdat het zuurbufferend vermogen van slib relatief laag is, is de benodigde zuurdosering $\left(\mathrm{mol} \mathrm{H}^{+} / \mathrm{mol} \mathrm{P}\right)$ bij extractie op ijzerarm slib vergelijkbaar met die voor verbrandingsassen (Ecophos proces) en lager dan die voor dierlijke mest. Bij het aanzuren treden vrijwel geen zware metalen in oplossing, waardoor het herwonnen fosfaat ruimschoots aan de normen voor zware metalen kan voldoen.

Voor de extractie van fosfaat uit ijzerarm slib is circa $36 \mathrm{~L} \mathrm{H}_{2} \mathrm{SO}_{4}$ en $17 \mathrm{~kg}\left(\mathrm{Ca}(\mathrm{OH})_{2}\right.$ per ton slibkoek nodig. De kosten voor het verbruik van zwavelzuur en kalkmelk worden geschat op circa $€ 6$ ton slibkoek. Bij gebruik van zwavelzuur kan het sulfaat worden teruggewonnen in de vorm van gips door dosering van extra calcium. Het wordt echter aanbevolen om ook alternatieven voor het gebruik van zwavelzuur te onderzoeken. Hierbij kan bijvoorbeeld gedacht worden aan het gebruik van zure industriële reststromen, biologische productie van organische zuren uit reststromen of het combineren van fosfaatterugwinning met tweetrapsvergisting waarbij fosfaat na de acidogene fase wordt teruggewonnen.

Door de beperkte vraag naar minerale fosfaatmeststoffen is de afzetwaarde van herwonnen fosfaten bij afzet in Nederland beperkt. Afzet als grondstof voor de productie van minerale fosfaatmeststoffen (vervanger van fosfaaterts) is daarom een gunstig alternatief. Er bestaat een mogelijkheid dat struviet uit communaal afvalwater onder voorwaarden wordt toegelaten tot het vrije handelsverkeer waardoor de afzetmogelijkheden zullen toenemen.

De bedrijfseconomische voordelen van vergaande fosfaatverwijdering op korte termijn moeten hoofdzakelijk gezocht worden in de afname van de kosten voor slibontwatering en -afzet. Vergaande fosfaatverwijdering leidt tot circa $6 \%$ afname in slibmassa. Daarnaast wordt verwacht dat de ontwatering verbetert, waardoor bespaard kan worden op het polymeerverbruik. Tevens neemt de marktwaarde van gedroogd slib als biobrandstof toe, omdat er bij verbranding van fosfaatverarmd slib $30 \%$ minder asresten overblijven dan bij onbehandeld slib. Vergaande fosfaatverwijdering in combinatie met afzet van gedroogd slib als biobrandstof vormt daarmee een gunstiger alternatief voor de afzet van slib naar monoverbranders. Afzet van het fosfaatverarmde slib naar de landbouw is onder de huidige wetgeving niet mogelijk, omdat de zuurextractie niet (koper) of onvoldoende (zink) leidt tot een afname in de gehalten aan zware metalen. 


\subsubsection{Milieurisicobeoordeling (zware metalen) bij landbouwkundig gebruik van zuiveringsslib}

In Nederland is het landbouwkundig gebruik van zuiveringsslib toegestaan, mits aan de voorgeschreven normen voor zware metalen en doseringsnormen wordt voldaan. Zuiveringsslib van communale RWZI's voldoet niet aan de normen voor zware metalen. Hierbij vormen voornamelijk koper en zink een knelpunt. Zuiveringsslib en gecomposteerd slib voldoen wel aan de toekomstige normen voor organische meststoffen zoals opgenomen in het ontwerp van de nieuwe EUMeststoffenverordening, maar producten uit afvalwater zijn hierbij expliciet uitgesloten.

Vanwege de grote verscheidenheid in normen voor zware metalen voor meststoffen en zuiveringsslib is er behoefte aan een beoordeling van de milieurisico's bij het gebruik van zuiveringsslib als meststof in vergelijking met andere reguliere mestsoorten waaronder dierlijke mest en compost. Het gebruik van zuiveringsslib als meststof in de landbouw leidt, evenals het gebruik van dierlijke mest en GFTcompost, tot accumulatie van koper en zink in landbouwgronden; de mate van accumulatie wijkt overigens niet af van die bij gebruik van dierlijke mest. Als gevolg van de accumulatie in de bodem stijgt op termijn ook de uitspoeling van koper en zink naar grond- en oppervlaktewater. De beoordeling van de consequenties daarvan staan momenteel ter discussie en de recentelijk ingevoerde correctie van de effectnormen op basis van beschikbaarheid kan leiden tot hogere acceptabele concentraties in oppervlaktewater. Of, en zo ja in welke mate, accumulatie van metalen in de bodem in dat geval nog beperkend zal zijn voor de aanwending van slib, valt buiten het bestek van deze studie. De accumulatie van overige zware metalen $(\mathrm{Cd}, \mathrm{Cr}, \mathrm{Hg}, \mathrm{Pb}, \mathrm{As})$ is verwaarloosbaar. De jaarlijkse aanvoer van zware metalen hangt samen met de dosering van slib die wordt bepaald door de combinatie van het fosfaatgehalte en het stelsel van fosfaatgebruiksnormen. Bij gebruik van nietverarmd zuiveringsslib is de belasting van de bodem met zware metalen echter lager dan bij het gebruik van dierlijke mest of compost. Wordt het fosfaatgehalte van slib met $50 \%$ verlaagd, dan is de koper- en zinkbelasting van de bodem vergelijkbaar met die bij bemesting met varkensmest of GFTcompost. Bij een verdere verlaging van het fosfaatgehalte van het slib neemt de belasting van landbouwgronden toe ten opzichte van referentiescenario's voor dierlijke mest. Geen van de scenario's leidt tot overschrijding van landbouwadvieswaarden (LAC-waarden) voor koper- of zinkgehalten in de bodem. Een beoordeling van de risico's ten aanzien van organische microverontreinigingen viel buiten het bereik van deze studie.

Toekomstige milieunormen worden mogelijk gebaseerd op reactiviteit van zware metalen in plaats van op totaalgehalten. Uit analyses blijkt dat vergisten zorgt voor een sterke afname in de reactiviteit van koper. Composteren en hydrothermale carbonisatie $\left(200^{\circ} \mathrm{C}\right)$ leiden tot een sterke afname in de reactiviteit van koper, nikkel en zink (alleen na hydrothermale behandeling). Indien toekomstige milieunormen worden afgeleid op basis van milieurisicobeoordelingen in plaats van op basis van een voorzorgsprincipe, kan dit leiden tot een verruiming van de afzetmogelijkheden voor slib en slibproducten.

\subsection{Perspectieven}

Zuiveringsslib vormt een bron van nutriënten en dan met name van fosfaat en organische stof die bij huidige slibverwerkings- en afzetroutes grotendeels verloren gaan. Vanwege de grote omvang van deze fosfaatstroom spelen terugwinning en hergebruik van fosfaat uit zuiveringsslib een belangrijke rol in het sluiten van de fosfaatkringloop.

Het is praktisch gezien haalbaar om circa $60 \%$ van het fosfaat uit slib te verwijderen en terug te winnen, mits het ijzergehalte van het slib voldoende laag is. Ongeveer de helft van de RWZI's kan aan deze voorwaarde voldoen. De kosten voor het verbruik van zuur en base worden geschat op $€ 6$ per ton slibkoek. Bij grootschalige terugwinning is, op dit moment, de afzet van het herwonnen fosfaat als grondstof voor de productie van fosfaatkunstmest het perspectiefvolst. In 2018 zal blijken of herwonnen fosfaten onder voorwaarden worden toegelaten tot het vrije handelsverkeer in de EU waardoor export als fosfaatmeststof eenvoudiger en gunstiger wordt. 
Vergaande fosfaatterugwinning uit slib leidt op de korte termijn tot de volgende (bedrijfseconomische) voordelen:

- Terugwinning van circa $60 \%$ van het fosfaat uit slibkoek in de vorm van minerale fosfaatmeststof/grondstof.

- Afname van de slibproductie met circa 6\% door verwijdering van $\mathrm{CaHPO}_{4}$-mineralen.

- Verbeterde slibontwatering door aanzuren en verwijderen bicarbonaat (niet gekwantificeerd).

- Hogere afzetwaarde bij de afzet van gedroogd slib als biobrandstof door afname van de hoeveelheid verbrandingsassen met ruim $30 \%$.

Het gebruik van zuiveringsslib als biobrandstof is een hoogwaardigere toepassing dan monoverbranding, waarbij netto gezien geen energie wordt gewonnen. De volgende stap in de waardepiramide is de afzet van fosfaat-verarmd slib naar de landbouw. Perspectieven hiervoor blijven echter nog onzeker. Op dit moment is toepassing van zuiveringsslib niet mogelijk vanwege overschrijdingen van normen voor zware metalen (koper, zink). Fosfaatextractie leidt nauwelijks tot een verlaging van de gehalten aan zware metalen, waardoor ook het fosfaatverarmde slib niet aan deze normen kan voldoen. Hierbij moet de kanttekening geplaatst worden dat de koper- en zinkbelasting bij gebruik van fosfaatverarmd slib vergelijkbaar is met die bij gebruik van mest, maar dat gehalten aan metalen in mest niet worden gereguleerd. Indien toepassingsmogelijkheden voor slib(producten) onder toekomstige wetgeving verruimen, moet echter rekening gehouden worden met het feit dat ook fosfaat-verarmd slib zal moeten concurreren met de afzet van dierlijke mest, waardoor de afzetwaarde afhangt van de ontwikkelingen op de mestmarkt. 


\section{Literatuur}

ADAS, 2001. Safe Sludge Matrix - Guidelines for the application of sewage sludge to agricultural land, www.adas.co.uk/matrix.

AbfKlärV, 2015. AbfKlärV: Klärschlammverordnung. Verkrijgbaar via:

http://www.bmub.bund.de/themen/wasser-abfall-boden/abfallwirtschaft/abfallartenabfallstroeme/klaerschlamm/ English version available at http://ec.europa.eu/growth/toolsdatabases/tris/en/search/?trisaction=search. detail\&year=2016\&num $=514$.

Andreadakis, A.D., Treatment and disinfection of sludge using quicklime. EC workshop. Toegankelijk via: http://ec.europa.eu/environment/archives/waste/sludge/pdf/workshoppart2.pdf

Barat, R., Montoya, T., Seco, A., Ferrer, J., 2005. The role of potassium, magnesium and calcium in the enhanced biological phosphorus removal treatment plants. Envrionmental Technology 26, 983-992.

Berkhof, D., Korving, L., 2016. De invloed van kationen en beluchting op slibontwatering.

Bisschops, I., Timmerman, M., Weijma, J., Van Eekert, M., de Buisonjé, F., Spanjers, H., 2011. Synergie RWZI en mestverwerking. Amersfoort, Stowa, Stowa-rapport 2011-10.

Bonten, L.T.C, Groenenberg, J.E., Koopmans, G.F., Romkens, P.F.A.M., Vink, J.P.M, en Verschoor, A., 2010. Uitspoeling van zware metalen uit bodems naar het oppervlaktewater. Wageningen, Alterra, Alterra-rapport 2024.

Busch, D., Glaser, B., 2015. Stability of co-composted hydrochar and biochar under field conditions in a temperate soil. Soil use and management, 31.

BVOR, 2014. BVOR jaarverslag 2014. www.bvor.nl/jaarverslagen.

BVOR, 2015. Compost, Sleutel tot een vruchtbare bodem. Nieuwsbulletin Jaargang 25, nummer 2, oktober 2015. www.bvor.nl.

CBS Statline. www.statline.cbs.nl.

Chen, Y., Yang, H., Gu, G., 2001. Effect of acid and surfactant treatment on activated sludge dewatering and settling. Water Research 35(11), 2615-2620.

Christian, R., 2015. Sustainable sewage sludge management fostering phosphorus recovery and energy efficiency. Deliverable D9.2. Life cycle assessment of selected processes for P recovery from sewage sludge, sludge liquor or ash, available at: www.p-rex.eu/uploads.

$\operatorname{COM}(2011)$ 257. Communication from the Commission to the European Parliament, the Council, the European Economic and Social Committee and the Committee of the Regions Roadmap to a Resource Efficient Europe.

$\operatorname{COM}(2013)$ 517. Communication from the Commission to the European Parliament, the Council, the European Economic and Social Committee and the Committee of the Regions Consultative Communication on the Sustainable Use of Phosphorus.

$\operatorname{COM}(2014) 297$. Communication on the review of the list of critical raw materials for the EU and the implementation of the Raw Materials Initiative.

COM-2016 (157). Voorstel voor een verordening van het Europees Parlement en de Raad tot vaststelling van voorschriften inzake het op de markt aanbieden van bemestingsproducten met CE-markering en tot wijziging van de Verordeningen (EG) nr. 1069/2009 en (EG) nr. 1107/2009.

DEFRA, 2016 (Department of Environment, Food and Rural Affairs). Code of Practice for Agricultural Use of Sewage Sludge. Accessible at: http://adlib.everysite.co.uk/adlib/defra/content. aspx?id=4197.

EC, 2008a. European Union Risk Assessment Report. Copper, Copper II sulphate pentahydrate, Copper(I)oxide, Copper(II)oxide, diCopper chloride trihydroxide. Brussels.

EC, 2008b. European Union Risk Assessment Reports on Zinc and Zinc compounds. Final report of May 2008. Part 1 Environment: European Chemicals Bureau, prepared by the Netherlands in the context of Council Regulation (EEC) No. 793/93.

Ehlert, P.A.I., Romkens, P.F.A.M., Rietra, R.P.J.J., Wintersen, A.M., Van Wijnen, H., Van Dijk, T.A., Scholl, L.V., Groenenberg, J.E., 2013. Appraising Fertilisers: Origins of current regulations and standards for contaminants in fertilisers, Wageningen UR-Alterra, Wageningen. 
Ehlert, P., 2005. Toepassing van de basisvrachtbenadering op fosfaat in compost. Wettelijke onderzoekstaken natuur en milieu, Wageningen, Alterra, WOt Rapport 5.

Escala, M., Zumbuhl, T., Koller, C., Junge, R., Krebs, R., 2012. Hydrothermal carbonization as an energy-efficient alternative to established drying technologies for sewage sludge: a feasibility study on a laboratory scale. Energy \& Fuels 27(1), 454-460.

Eyser, C vom, Schmidt, T.C., Tuerk, J., 2016. Fate and behaviour of diclofenac during hydrothermal treatment. Chemosphere 153, 280-286.

European Communities, 2001. Disposal and recycling routes for sewage sludge Part 2 -Regulatory report, http://ec.europa.eu/environment/archives/waste/sludge/pdf/sludge_disposal2.pdf.

European Commission, 2016a. Call for applications for membership in the Commission expert group on recovery rules for fertilising products. Published at 29/04/2016. Accessible at http://ec.europa.eu/growth/tools-databases/newsroom/cf/itemdetail.cfm?item_id=8798.

Evers, M., Vroegrijk, M., Evers, T., 2016. Struviet en struviethoudende producten uit communaal afvalwater - Marktverkenning en gewasonderzoek, Stowa, Amersfoort.

Heilmann, S.M., Molde, J.S., Timler, J.G., Wood, B.M., Mikula, A.L., Vozhdayev, G.V., Colosky, E.C., Spokas, K.A., Valentas, K.J., 2014. Phosphorus reclamation through hydrothermal carbonization of animal manures. Environmental science \& technology 48(17), 10323-10329.

Hoekman, S.K., Broch, A., Robbins, C., Zielinska, B., Felix, L., 2013. Hydrothermal carbonization (HTC) of selected woody and herbaceous biomass feedstocks. Biomass Conversion and Biorefinery $3(2), 113-126$.

IJzerman, J., Mulder, M., Brinkmann, A., Miltenburg, S., 2014. Perspectieven en knelpunten van zuiveringsslib voor bodemkundig gebruik. Stowa, Rapport 35 - 2014.

Jossa, P., Remy, C., 2015. Life cycle assessment of selected processes for P recovery from sewage sludge, sludge liquor or ash, Kompetenz Wasser - Berlin, Germany.

Reza, M.T., Lynam, J.G., Uddin, M.H., Coronella, C.J., 2013. Hydrothermal carbonization: fate of inorganics. Biomass and Bioenergy 49, 86-94.

Koeijer, T.J. de, H.H. Luesink en P.W. Blokland, 2016. Effecten van derogatie op de kosten van mestafzet. Wageningen, LEI Wageningen UR, LEI Report 2016-024.

Koeijer, T.J. de, H.H. Luesink, 2017. Dieraantallen, mestproductie, mestmarkt en kosten mestafzet, Wageningen, Wageningen Economic Research, report 2017-002.

Kuroda, A., Takiguchi, N., Gotanda, T., Nomura, K., Kato, J., Ikeda, T., Ohtake, H., 2002. A simple method to release polyphosphate from activated sludge for phosphorus reuse and recycling. Biotechnology and Bioengineering 78(3).

Lodder, R., Meulenkamp, R., Notenboom, G. Fosfaatterugwinning in communale afvalwaterzuiveringsinstallaties. Amersfoort, Stichting Toegepast Onderzoek Waterbeheer, Stowa rapport 2011-42.

Lijzen, J., A Verschoor, M. Mesman, P. de Boer, L. Osté, Deltares, en P. Römkens. 2017. Visiedocument gebruik van biobeschikbaarheid in bodembeoordeling. Mogelijkheden voor metalen in bodem en waterbodem. RIVM Briefrapport 2015-0215.

Marchioretto, M.M., Rulkens, W.H., Bruning, H., 2005. Heavy metals precipitation in sewage sludge. Seperation Science and Technology 40, 3393-3405.

Mestportaal, 2016. Mestmarkt, www.mestportaal.nl/mestmarkt.

Morgenschweis, C., Vergouwen, L., Scholl, L.V., I, L., 2015. Verkenning van de kwaliteit van struviet uit de communale afvalwaterketen.

Milieu Ltd, WRc and RPA. 2008. Environmental, economic and social impacts of the use of sewage sludge on land. Final Report. Part III: Overview Report. European Commission, DG Environment under Study Contract DG ENV.G.4/ETU/2008/0076r. Verkrijgbaar via: http://ec.europa.eu/environment/archives/waste/sludge/pdf/part_iii_report.pdf.

Mol, G., Gaans, P.F.M., J. Spijker, G., Van der Veer, G., Klaver, G., Roskam, G., 2010. Geochemische atlas van Nederland, Alterra-Wageningen UR.

Montag, W., Everding, S Malms et al., 2015. Bewertung konkreter massnahmen einer weitergehende phosphorruckgewinnung aus relevanten stoffstromen sowie zum effizienten phosphoreinsatz, Umweltbudensamt, Dessau-Rossblau.

Nättorp, A., 2013. Recovery technologies and products. Verkrijgbaar via: http://p-rex.eu/fileadmin/PREX-Reserach/Recovery_technology_and_products_FHNW.pdf.

Richtlijn 86/278/EEG van de Raad van 12 juni 1986 betreffende de bescherming van het milieu, in het bijzonder de bodem, bij het gebruik van zuiveringsslib in de landbouw. 
Portal of the Swiss confernment, 2016. Revidierte Technische Verordnung über Abfälle: Schritt zur Ressourcenschonung. Accesible at https://www.admin.ch/gov/de/start/dokumentation/medienmitteilungen.msg-id-59785.html.

ReVaQ, 2105. REVAQ certified wastewater treatment plants in Sweden. Accesible at: Shttps://www.iea-biogas.net/case-studies.html?file=files/daten-redaktion/download/casestudies/REVAQ_CAse_study_A4_1.pdf.

Römkens, P.F.A.M., Groenenberg, J.E., Bonten, L.T.C., de Vries, W., Bril, J., 2004. Derivation of partition relationships to calculate $\mathrm{Cd}, \mathrm{Cu}, \mathrm{Ni}, \mathrm{Pb}$ and $\mathrm{Zn}$ solubility and activity in soil solutions. Wageningen, Alterra, Alterra rapport 305.

Römkens, P.F.A.M., Groenenberg, J.E., Rietra, R.P.J.J., de Vries, W., 2007. Onderbouwing LAC-2006 waarden en overzicht van bodem-plant relaties ten behoeve van de Risicotoolbox: een overzicht van gebruikte data en toegepaste methoden. Wageningen, Alterra, Alterra rapport 1442.

Römkens, P.F.A.M., \& R.P.J.J. Rietra, 2008. Zware metalen en nutriënten in dierlijke mest in 2008; Gehalten aan $\mathrm{Cd}, \mathrm{Cr}, \mathrm{Cu}, \mathrm{Hg}, \mathrm{Pb}, \mathrm{Zn}, \mathrm{As}, \mathrm{N}$ en $\mathrm{P}$ in runder-, varkens-, en kippenmest. Wageningen, Alterra, Alterra-rapport 1729.

RVO.nl, 2016. Tabel 2. Fosfaatgebruiksnormen 2015-2017. http://www.rvo.nl/onderwerpen/agrarischondernemen/mest-en-grond/mest/tabellen-en-publicaties/tabellen-en-normen.

Sahlström, L., Aspan, A., Bagge, E., Danielsson-Tham, M., Albihn, A., 2004. Bacterial pathogen incidences in sludge from Swedish sewage treatment plants. Water research 38, 1989-1994.

SEPA, 2005. A Strategy for Sustainable Waste Management Sweden's Waste Plan. Swedish Environmental Protection Agency. Accessible at https://www.naturvardsverket.se/Documents/publikationer/620-1249-5.pdf.

SEPA, 2014. Waste Water Treatment. Swedish Environmental Protection Agency, accessible at https://www.naturvardsverket.se/Documents/publikationer6400/978-91-620-87043.pdf?pid=13165.

Schoumans, O.F., P.A.I. Ehlert, J.A. Nelemans, W. van Tintelen, W.H. Rulkens and O. Oenema, 2014. Explorative study of phosphorus recovery from pig slurry; Laboratory experiments. Wageningen, Alterra Wageningen UR (University \& Research centre), Alterra report 2514. 46 blz.; 24 fig.; 9 tab.; 31 ref.

Schoumans, O.F., Ehlert, P.A.I., Regelink, I.C., Nelemans, J.A., Noij, I.G.A.M., van Tintelen, W., Rulkens, W.H., Oenema, O., 2017. Chemical phosphorus recovery from animal manure and digestate. Wageningen Environmental Research. In press.

Snijders, J.M., 2011. Waterkwaliteitsrapportage 2010. Royal Haskoning.

Starmans, D.A.J., Melse, R.W., 2011. Alternatieven voor zwavelzuur in luchtwassers, Wageningen UR Livestock Research.

TCB, 1989. Advies ontwerp-besluit gebruik en kwaliteit overige organische meststoffen. Technische commissie bodembescherming TCB A89/02.

TCB, 1991. Advies Ontwerp-besluit gebruik en kwaliteit overige organische meststoffen. Technische Commissie Bodembescherming. TCBA90/04. Leidschendam.

UBM, 2016. Uitvoeringsbesluit Meststoffenwet - Bijlage III. http://wetten.overheid.nl/BWBR0019031/2016-01-01\#BijlageIII.

UvW, 1980. Richtlijn voor de afzet van vloeibaar zuiveringsslib ten behoeve van gebruik op bouw- en grasland. Unie van Waterschappen.

UvW, 1985. Richtlijn voor de afzet van vloeibaar zuiveringsslib ten behoeve van gebruik op bouw- en grasland. Unie van Waterschappen.

Veltman, A., 2012. Struviet productie door middel van het Airprex proces. Stichting Toegepast Onderzoek Waterbeheer. STOWA 2012-27.

Weiner, B., Baskyr, I., Poerschmann, J., Kopinke, F.-D., 2013. Potential of the hydrothermal carbonization process for the degradation of organic pollutants. Chemosphere 92(6), 674-680.

Wirth, B., Reza, M.T., 2016. Continuous anaerobic degradation of liquid condensate from steamderived hydrothermal carbonization of sewage sludge. ACS Sustainable Chemistry \& Engineering 4(3), 1673-1678. 


\section{Bijlage 1 Analysemethoden}

Deze bijlage geeft een aanvulling op de korte beschrijvingen van de analysemethoden gebruikt in $\mathrm{H} 4$ en 5 .

\section{Voorbehandeling}

Het slib is gedurende de looptijd van de experimenten gekoeld bewaard bij $4{ }^{\circ} \mathrm{C}$. Daarnaast is er een submonster van het slib gedroogd $\left(100^{\circ} \mathrm{C}\right)$ en gemalen. Dit droge materiaal is gebruikt voor bepaling van de destructie en de $\mathrm{HNO}_{3}$-extractie.

\section{Drogestofgehalte:}

Het droge stof gehalte is bepaald bij 105 graden ${ }^{\circ} \mathrm{C}$.

\section{Organisch stofgehalte:}

Het organisch stof gehalte is bepaald op basis van het gloeiverlies tussen 105 en 500 graden ${ }^{\circ} \mathrm{C}$.

\section{Organisch koolstofgehalte:}

Het organisch C-gehalte is bepaald door middel van een LECO CN analyzer op gedroogde monsters.

\section{Elementaire samenstelling (destructie)}

De elementaire samenstelling is bepaald na destructie van gedroogd slib in Aqua Regia. De samenstelling van het destruaat is bepaald met behulp van ICP-AES en ICP-MS.

\section{Totaal P en $\mathbf{N}$}

De bepaling voor totaal $\mathrm{P}$ en $\mathrm{N}$ is uitgevoerd op vers slib en biogranulaat om stikstofverliezen door drogen te voorkomen. De monsters zijn gedestrueerd met $\mathrm{H}_{2} \mathrm{SO}_{4} / \mathrm{H}_{2} \mathrm{O}_{2} / \mathrm{Se}$. De concentraties ortho-P en $\mathrm{N}$ in de destruaten zijn colorometrisch bepaald met behulp van een spectrofotometer. $\mathrm{N}$ is bepaald volgens de indophenol-blue-methode en orthoP is bepaald volgens de molybdenum-blue-methode.

\section{Beschikbare (reactieve) metalen}

Gehaltes aan reactieve metalen zijn bepaald na extractie in $0.43 \mathrm{M} \mathrm{HNO}_{3}$. De extractie is uitgevoerd bij een schudverhouding van $0.1 \mathrm{~kg} / \mathrm{l}$ en een schudtijd van 1 uur. Concentraties aan zware metalen in de gefiltreerde extracten zijn bepaald met ICP-AES ( $\mathrm{Cu}, \mathrm{Zn}, \mathrm{Ni}, \mathrm{Cd})$ en ICP-MS ( $\mathrm{Cr}, \mathrm{As}, \mathrm{Pb})$.

\section{Fosfaatspeciatie (organisch, anorganisch, polyfosfaat)}

De verdeling van totaal $\mathrm{P}$ over anorganisch en organisch $\mathrm{P}$ is bepaald met de Pkuo-methode. Anorganisch $\mathrm{P}$ (orthoP + polyP) is bepaald na extractie met $0.5 \mathrm{M} \mathrm{H}_{2} \mathrm{SO}_{4}$. Totaal $\mathrm{P}$ is bepaald na destructie van de organische stof bij $550{ }^{\circ} \mathrm{C}$, gevolgd door een $0.5 \mathrm{M} \mathrm{H}_{2} \mathrm{SO}_{4}$ extractie. Organisch $\mathrm{P}$ is gedefinieerd als het verschil tussen totaal $\mathrm{P}$ en anorganisch $\mathrm{P}$. Polyfosfaat is gehydrolyseerd bij $80{ }^{\circ} \mathrm{C}$ en daarna geëxtraheerd bij pH 3.0 (zwavelzuur) (Kuroda et al. 2002). Het polyfosfaatgehalte is berekend als het verschil in orthoP geëxtraheerd bij pH 3.0 voor en na verhitting. OrthoPconcentraties zijn colorimetrisch bepaald na filtratie over $0.45 \mu \mathrm{m}$.

\section{Extracties met zwavelzuur}

Voor het uitvoeren van de zuurtitraties is vers slib aangelengd met water tot een slurry met een droge stof gehalte van $10 \%$, met uitzondering van Zutphen (3.7\% d.s.). In een bekerglas is 500 gram slurry stapsgewijs getitreerd tot $\mathrm{pH} 3.0$ met een $1 \mathrm{M} \mathrm{H}_{2} \mathrm{SO}_{4}$ oplossing. $\mathrm{Na}$ iedere zuur-toevoeging is de $\mathrm{pH}$ gemeten, welke binnen enkele minuten een constante waarde aangaf. Tijdens de titratie is de slurry continu geroerd door middel van een magneetroerder. Bij aanvang van de titratie en bij pH 6.0, 5.0, 4.0 en 3.0 is een monster $(10 \mathrm{~g})$ genomen van de slurry. Om de samenstelling van de waterfase te kunnen analyseren, zijn deze submonsters 20 keer verdund, gecentrifugeerd (10.000 rpm) en gefiltreerd over $0.45 \mu \mathrm{m}$. De samenstelling van het filtraat is vervolgens geanalyseerd op de concentratie aan ortho-P (SFA) en op concentraties van kationen en zware metalen (ICP-AES). 
In een aanvullende test is aangetoond dat de gehanteerde reactietijd van enkele minuten voldoende is om een evenwichtssituatie te bereiken; het aanzuren van slib en vervolgens laten schudden gedurende 24 uur gaf geen verhoging in orthoP-concentraties.

\section{Methodiek bepaling fosfaatspeciatie in zuiveringsslib}

De verdeling van fosfaat over de diverse organische en anorganische vormen is bepaald op basis van analyses en een aantal aannames, die hieronder worden toegelicht. De berekende speciatie is vervolgens gevalideerd aan de hand van de uitkomsten van de zuurtitraties (molverhoudingen van $\mathrm{P}$, $\mathrm{Fe}$, $\mathrm{Ca}$ en $\mathrm{Mg}$ in de waterfase).

Bij de berekening van de fosfaatspeciatie zijn de volgende aannames gebruikt:

- OrthoP (waterfase): bepaling

- Anorganisch P: bepaling

- Organisch P: Totaal P - Anorganisch P

- PolyP: verschilmeting voor en na hydrolyse van polyP

De verdeling van anorganisch $\mathrm{P}$ over de diverse minerale vormen is als volgt berekend:

- In vergist slib (anaeroob) is ijzer aanwezig in gereduceerde vorm Fe(II) en vormt het met fosfaat een neerslag van vivianiet $\left(\mathrm{Fe}(\mathrm{II}) \mathrm{HPO}_{4}\right.$ ) met een $\mathrm{P} / \mathrm{Fe}$ molverhouding van $1: 1$.

- In niet-vergist slib (aeroob/anoxisch) is Fe aanwezig in geoxideerde vorm en vindt binding van fosfaat plaats door adsorptie aan Fe(III)hydroxiden en Al-hydroxiden. De hoeveelheid fosfaat gebonden aan $\mathrm{Fe}$ en $\mathrm{Al}$ is berekend op basis van de maximale bindingscapaciteit van Fe- en $\mathrm{Al}$ (molverhouding $0.5 \mathrm{P} /(\mathrm{Fe}+\mathrm{Al})$.

- De hoeveelheid $\mathrm{P}$ in de vorm van $\mathrm{CaHPO}_{4}$ is berekend op basis van het Ca-gehalte en een $\mathrm{Ca} / \mathrm{P}$ verhouding van 1:1 (of lager wanneer het $\mathrm{P}$-gehalte reeds beperkend is).

- De hoeveelheid $\mathrm{P}$ in de vorm van struviet $\left(\mathrm{MgNH}_{4} \mathrm{PO}_{4}\right)$ is berekend op basis van het $\mathrm{Mg}$-gehalte en een $\mathrm{Mg} / \mathrm{P}$ molverhouding van 1:1 (of lager wanneer het $\mathrm{P}$ gehalte reeds beperkend is).

- Bij de vastlegging van $\mathrm{P}$ met $\mathrm{Fe}$ is niet gecorrigeerd voor vastlegging van $\mathrm{Fe}(\mathrm{II})$ met sulfide $\left(\mathrm{S}^{2-}\right)$ in de vorm van pyriet (FeS). De hoeveelheid Fe in de vorm van pyriet is verwaarloosbaar klein, omdat analyses uitwijzen dat zwavel (S) voor maximaal $15 \%$ aanwezig is de vorm van sulfide. Zwavel is hoofdzakelijk aanwezig is in de vorm van organisch zwavel wat niet bindt met ijzer. Onderscheid tussen organisch en anorganisch zwavel is gemaakt op basis van een $0.43 \mathrm{M} \mathrm{HNO}_{3}$-extract, waarbij is aangenomen dat alleen anorganisch zwavel (sulfide, sulfaat) oplosbaar is in $\mathrm{HNO}_{3}$. 


\section{Bijlage 2 Zuurtitraties zuiveringsslib}

Extra figuur zuur-titraties (Hd 4) waarbij concentraties zijn weergegeven in mol/l.

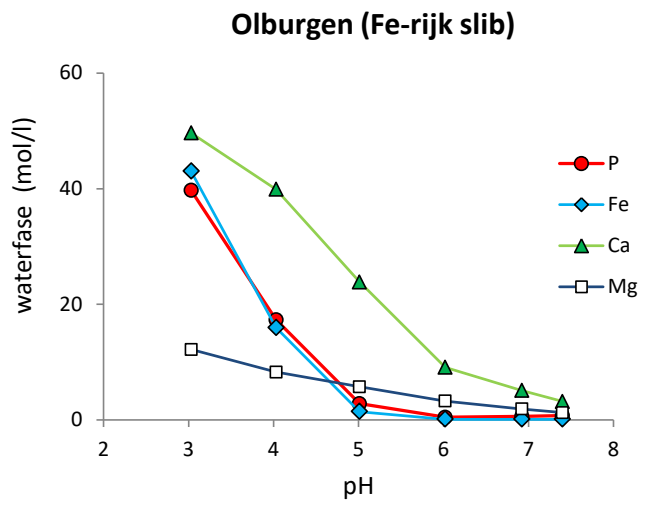

Den Bosch (Fe-rijk slib)

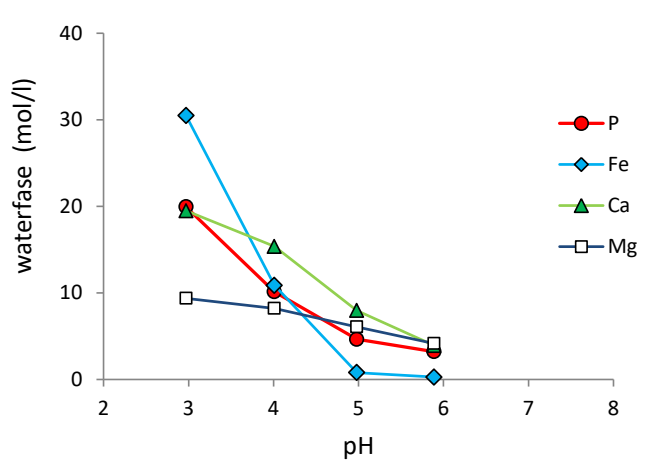

Zutphen (BioP)

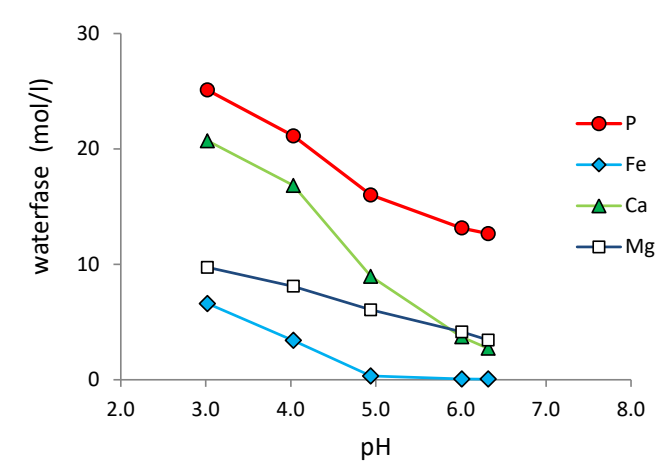

Oijen (BioP + Al )

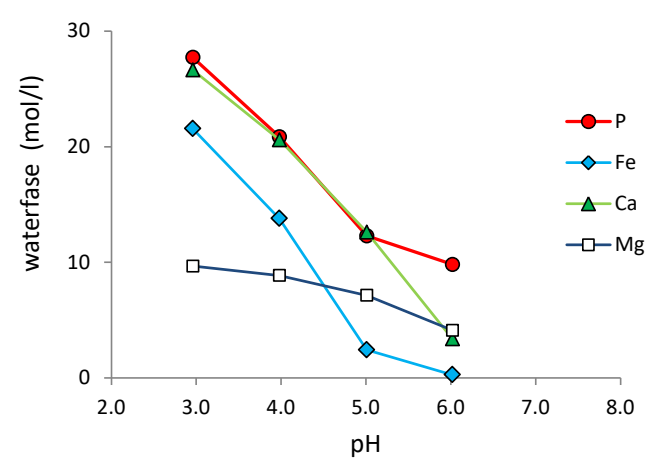

Etten (BioP + Fe )

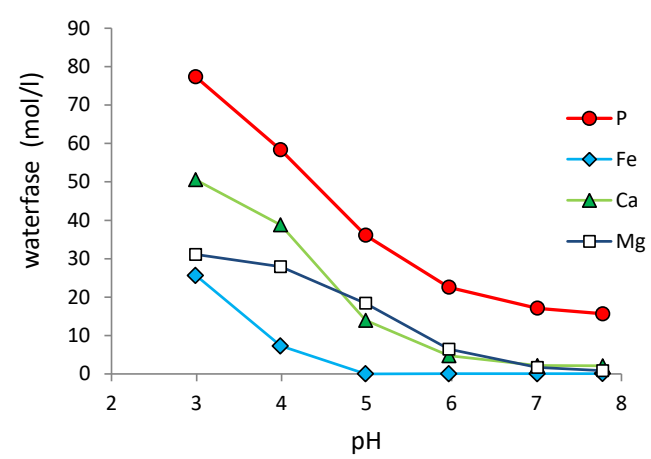

Nieuwgraaf (BioP + Fe)

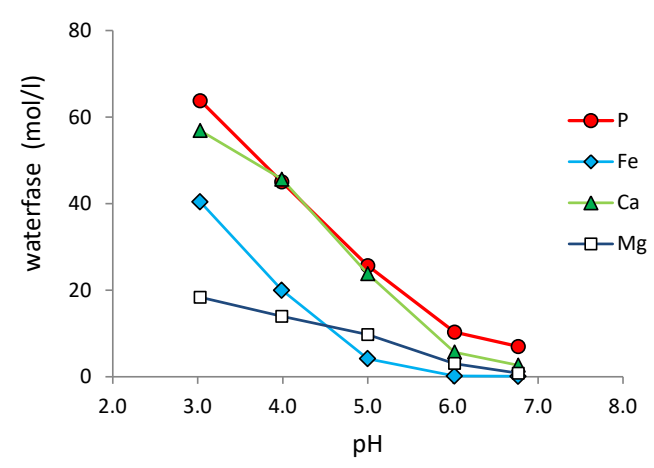

Figuur B2.1 Resultaten van de zuurtitraties met zwavelzuur. Concentraties van P, Mg, Ca, Fe en Al in mol/L in de waterfase van het slib (bij extractie op slib met $10 \%$ droge stof). 
Aarle Rixtel (niet vergist)

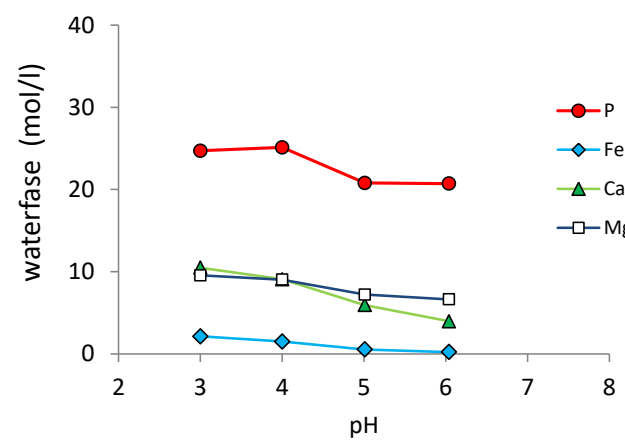

A'dam (voor struviet)

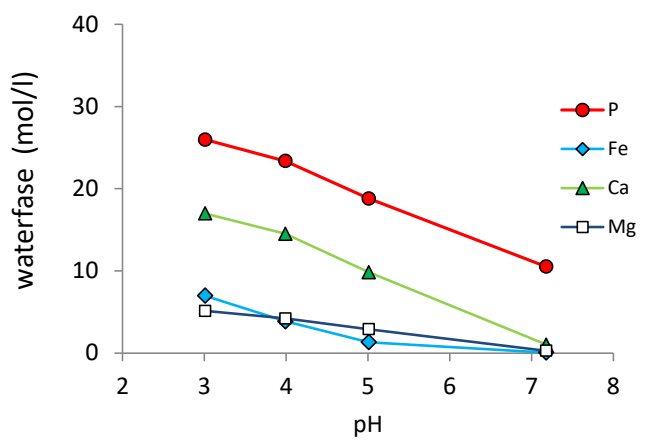

Asten (vergist)

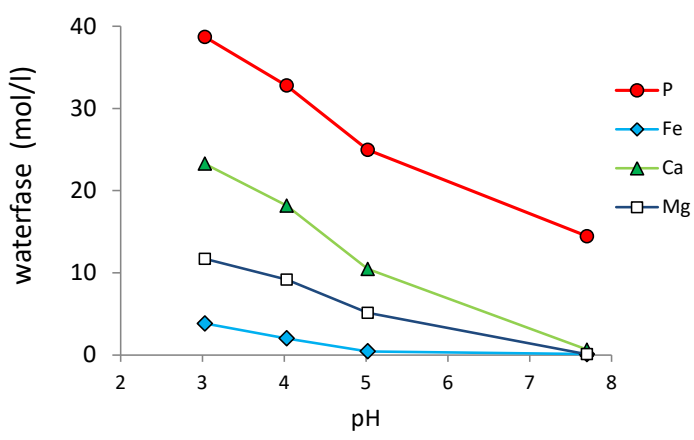

A'dam (na struviet)

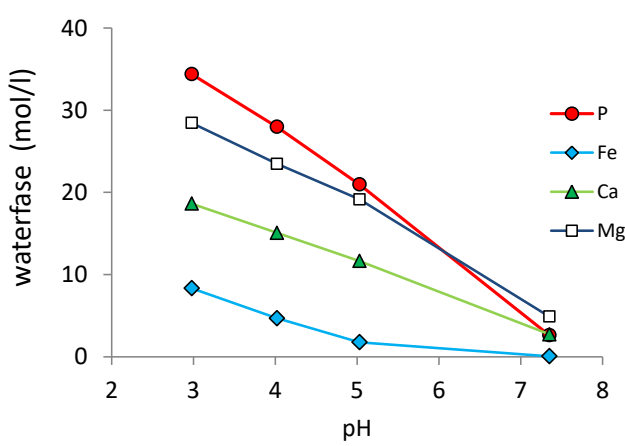

Figuur B2.2 Resultaten van de zuurtitraties met zwavelzuur op ingedikt slib. Concentraties van $P, M g$, $\mathrm{Ca}$, Fe en $\mathrm{Al}$ in $\mathrm{mol} / \mathrm{L}$ in de waterfase van het slib (bij extractie op slib met $10 \%$ droge stof). 
Wageningen Environmental Research Postbus 47

6700 AA Wageningen

T 0317480700

www.wur.nl/environmental-research

Wageningen Environmental Research Rapport 2819

ISSN 1566-7197
De missie van Wageningen University \& Research is 'To explore the potential of nature to improve the quality of life'. Binnen Wageningen University \& Research bundelen Wageningen University en gespecialiseerde onderzoeksinstituten van Stichting Wageningen Research hun krachten om bij te dragen aan de oplossing van belangrijke vragen in het domein van gezonde voeding en leefomgeving. Met ongeveer 30 vestigingen, 5.000 medewerkers en 10.000 studenten behoort Wageningen University \& Research wereldwijd tot de aansprekende kennisinstellingen binnen haar domein. De integrale benadering van de vraagstukken en de samenwerking tussen verschillende disciplines vormen het hart van de unieke Wageningen aanpak. 



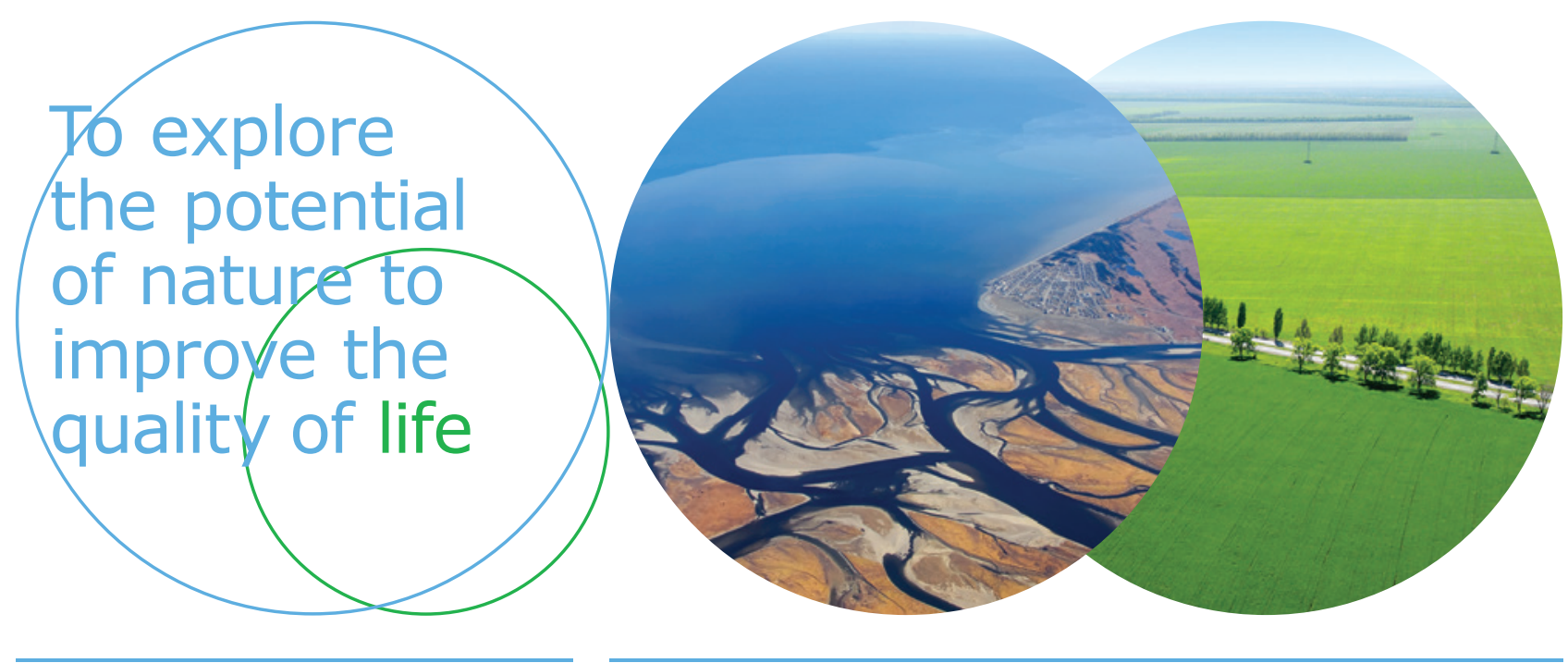

Wageningen Environmental Research Postbus 47

$6700 \mathrm{AB}$ Wageningen

T 317480700

www.wur.nl/environmental-research

Rapport 2819

ISSN 1566-7197
De missie van Wageningen University \& Research is 'To explore the potential of nature to improve the quality of life'. Binnen Wageningen University \& Research bundelen Wageningen University en gespecialiseerde onderzoeksinstituten van Stichting Wageningen Research hun krachten om bij te dragen aan de oplossing van belangrijke vragen in het domein van gezonde voeding en leefomgeving. Met ongeveer 30 vestigingen, 5.000 medewerkers en 10.000 studenten behoort Wageningen University \& Research wereldwijd tot de aansprekende kennisinstellingen binnen haar domein. De integrale benadering van de vraagstukken en de samenwerking tussen verschillende disciplines vormen het hart van de unieke Wageningen aanpak. 